UNIVERSIDADE DE SÃO PAULO

FACULDADE DE FILOSOFIA, LETRAS E CIÊNCIAS HUMANAS

DEPARTAMENTO DE CIÊNCIA POLÍTICA

PROGRAMA DE PÓS-GRADUAÇÃO EM CIÊNCIA POLÍTICA

Eduardo José Grin

CAMINHOS E DESCAMINHOS DAS SUBPREFEITURAS NA CIDADE DE SÃO PAULO NO GOVERNO MARTA SUPLICY (2001-2004)

Versão corrigida

São Paulo

2011 


\author{
UNIVERSIDADE DE SÃO PAULO \\ FACULDADE DE FILOSOFIA, LETRAS E CIÊNCIAS HUMANAS \\ DEPARTAMENTO DE CIÊNCIA POLÍTICA \\ PROGRAMA DE PÓS-GRADUAÇÃO EM CIÊNCIA POLÍTICA
}

\title{
CAMINHOS E DESCAMINHOS DAS SUBPREFEITURAS NA CIDADE DE SÃO PAULO NO GOVERNO MARTA SUPLICY (2001-2004)
}

Versão corrigida

Eduardo José Grin

\begin{abstract}
Dissertação submetida ao Programa de Pós-Graduação em Ciência Política, Departamento de Ciência Política, Faculdade de Filosofia, Letras e Ciências Humanas, Universidade de São Paulo, como parte dos requisitos necessários para a obtenção do título de Mestre em Ciência Política.
\end{abstract}

Orientador: Prof. Dr. Eduardo César Leão Marques 


\section{AGRADECIMENTOS}

Ao professor Eduardo Marques, orientador sempre disponível que ajudou a organizar as ideias dispersas em torno do tema e estimulou que a análise sempre fosse mais além das aparências para entender os porquês dos fatos. Aos professores Fernando Limongi e Marta Arretche, cujas críticas e sugestões no Exame de Qualificação dessa dissertação ajudaram sobremaneira a reorientar as hipóteses e o curso da pesquisa. Aos demais professores do Departamento de Ciência Política da USP, em especial aqueles com que tive oportunidade de cursar suas disciplinas no mestrado: Maria Hermínia Tavares de Almeida, Fernando Limongi, Leandro Piquet, Wagner Pralon e Oliveiros Ferreira. Um especial agradecimento ao professor Cícero Araújo pelo material disponibilizado e por me colocar em contato com integrantes do governo Marta Suplicy, o que facilitou a realização das entrevistas. Agradeço à professora Marta Farah pela oportunidade de cursar sua disciplina na FGV-SP, pois a literatura sobre a descentralização de políticas públicas no Brasil em muito ajudou as reflexões desse trabalho.

Aos Subprefeitos da Freguesia do Ó, Capela do Socorro, São Miguel Paulista e respectivos Coordenadores e assessores que gentilmente me concederam as entrevistas e me ajudaram a compreender a realidade da descentralização nos territórios em São Paulo. Da mesma forma, o agradecimento à Secretária de Assistência Social, Aldaíza Sposati, ao Chefe de Gabinete da Secretaria de Governo, Ubiratan Santos e ao Coordenador do Orçamento Participativo, Félix Sanchez, pelas entrevistas concedidas.

Aos funcionários do Arquivo Histórico Municipal, Secretaria Municipal de Planejamento, sobretudo, a Isabel Mezzalira na Secretaria Municipal de Cultura pela força e empréstimo de seu acervo sobre a reforma administrativa no governo Erundina.

Ao pai (in memorian) e a mãe, amigos de toda hora, minha gratidão sem fim. Aos meus filhos Artur, Carol e Pedro, mesmo distantes, sempre presentes na minha vida.

À Anita, pelo seu amor e carinho enorme, por sua companhia alegre e ao mesmo tempo zelosa para me apoiar na realização dessa pesquisa, servir de interlocutora das minhas dúvidas e sempre me estimular a prosseguir nesse retorno às atividades acadêmicas. 
"Incontestável e constituindo elemento essencial da História, ao qual não fazemos justiça em nossos dias, é o fato seguinte: o resultado final da atividade política raramente corresponde à intenção original do agente. Cabe mesmo afirmar que muito raramente corresponde e que, frequentemente, a relação entre o resultado final e a intenção primeira é simplesmente paradoxal. Esta constatação não pode, contudo, servir de pretexto para que se fuja à dedicação ao serviço de uma causa, pois que, se assim ocorresse, a ação perderia toda a coerência interna. Quanto à natureza da causa em nome da qual o homem político procura e utiliza o poder, nada podemos adiantar: ela depende das convicções pessoais de cada um. O homem político pode dedicar-se ao serviço de fins nacionais ou humanitários, sociais, éticos ou culturais, profanos ou religiosos. Pode também estar apoiado em sólida crença no "progresso" - nos diferentes sentidos dessa palavra - ou afastar totalmente essa crença; pode pretender servir, para apenas cultuar fins materiais de vida cotidiana. Seja qual for o caso, uma crença qualquer é sempre necessária, pois, caso contrário - e ninguém pode negá-lo - a inanidade da criatura eclipsará até mesmo o êxito político aparentemente sólido”.

Max Weber em

Ciência e Política: duas vocações

"Quando se põe o problema do "novo modo de fazer política"- como uma fórmula, aliás desgastada pelo longo uso e pelo abuso, e como todas as fórmulas políticas, carregada mais de força sugestiva que de significado - não se deve dirigir a atenção apenas para os eventuais novos sujeitos e para os eventuais novos instrumentos de intervenção, mas também, acima de tudo, para as regras do jogo com as quais se desenrola a luta política num determinado contexto histórico.” 


\section{RESUMO}

O objetivo desta dissertação é analisar a implantação das Subprefeituras na cidade de São Paulo no governo de Marta Suplicy (2001-2004) como mecanismo para descentralizar atividades e recursos para serem geridos nos territórios. A pesquisa buscou compreender como esse processo adotou sua configuração política e administrativa em face da forma como o Executivo transformou esse tema no principal recurso político para construir sua coalizão de apoio junto aos vereadores. Ao mesmo tempo, essa escolha política resultou num afastamento do governo do PT da tese que vinculava descentralização com poder local e democracia participativa nos territórios. A despeito de o Orçamento Participativo ter existido, seu peso na estratégia política do governo foi secundário, ademais de ter havido um recuo na implantação dos Conselhos de Representante para não por em risco a política de alianças, visto que os vereadores eram contrários a uma instância que fiscalizaria sua atuação. Administrativamente, a descentralização tomou um curso errático, pois as Secretarias municipais temerosas de perderem poder para as Subprefeituras, o que constrangeu a forma, o ritmo e o escopo da descentralização. Desse modo, ao invés de ocorrer um processo uniforme e geral, a implantação das Subprefeituras foi irregular, já que dependeu da dinâmica de cada política setorial e seus desdobramentos nas regiões. Para tratar essas duas questões, a pesquisa realiza uma análise geral desse projeto de governo e seleciona dois casos (Freguesia do Ó e Capela do Socorro) visando discutir como tais impasses e escolhas políticas se expressaram nos territórios.

Palavras chave: Subprefeituras, Descentralização, Democracia Participativa, Coalizões Políticas, Vereadores, Intersetorialidade de Políticas 


\begin{abstract}
The goal of this dissertation is to analyze the implementation of the Subdistricts in the city of São Paulo in the Marta Suplicy's government (2001-2004) as a mechanism to decentralize activities and resources to be managed in the territories. The research sought understanding how this process took its political and administrative configuration inface of how the Executive transformed this issue in the main political resource to build his support coalition along with the aldermen. At the same time, this political choice resulted in a departure from the PT government's argument that linked local decentralization with participatory democracy in the territories. Despite of the existence of the Participatory Budget, its weight in thegovernment's political strategy was secondary, furthermore there has been a retreat in the implementation of the Councils of Representatives to not endanger the policy of alliances, because the aldermen were opposed to a body that would supervise their work. Administratively, the decentralization took an erratic course, because the municipal Departments were fearful of losing power to the Subdistricts, which constrained the way, the pace and scope of decentralization. Thus, instead of incurring a general and uniform process, the implementation of the Subdistricts was uneven, since it depended on the dynamics of each of the sectors and its development in the territories. To analyze this issues, the research conducts a general analysis of this government project and selects two cases (Freguesia do Ó and Capela do Socorro) addressing to discuss how such deadlocks and political choices were expressed in the territories.
\end{abstract}

Key words: Subdistricts, Decentralization, Participatory Democracy, Political Coalitions, Aldermen, Intersectionof Policies 


\section{SUMÁRIO}

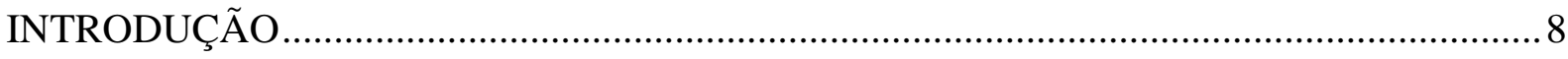

1 ATORES POLÍTICOS E SUAS ESTRATÉGIAS EM CONTEXTOS DE MUDANÇA POLÍTICA E ADMINISTRATIVA.............................................................................18

2 CONSTRUÇÃO E DESCONSTRUÇÃO NA IMPLANTAÇÃO DAS SUBPREFEITURAS NA CIDADE DE SÃO PAULO....................................................................................

3 A SUBPREFEITURA DA FREGUESIA DO Ó: A DINÂMICA DA RUPTURA POLÍTICA E A DESCENTRALIZAÇÃO ALTERADA ………………………………….....69

4 A SUBPREFEITURA DA CAPELA DO SOCORRO: A DINÂMICA DA HEGEMONIA POLÍTICA E A DESCENTRALIZAÇÃO CONTINUADA ……………………………........... 87

CONCLUSÃO

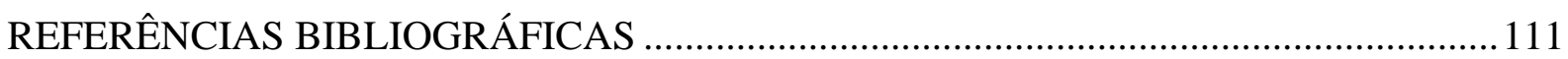

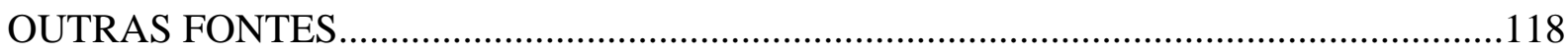

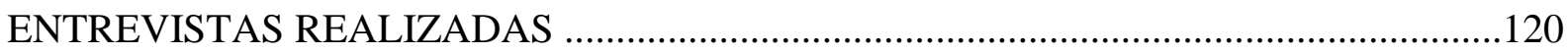




\section{INTRODUÇÃO}

Maquiavel (1983) já lembrava que nada é mais difícil de executar, mais duvidoso de ter êxito ou mais perigoso de manejar do que dar início a uma nova ordem de coisas. Se mudanças institucionais alteram a configuração administrativa e, portanto, a partilha de poder entre atores políticos, o postulado maquiavélico parece ser ainda mais contundente. Quando o governo petista da prefeita Marta Suplicy (2001-2004) encetou a descentralização políticoadministrativa no município de São Paulo e implantou as Subprefeituras, essa dificuldade influenciou o seu escopo. A descentralização territorial, concebida na administração petista de Luiza Erundina (1989-1992), não logrou êxito. Os governos seguintes de Paulo Maluf e Celso Pitta eram contrários a esse modelo político-administrativo. A "ordem das coisas" se manteve e as Administrações Regionais continuaram a ser o modo de o Executivo prestar serviços nas regiões e, ao mesmo tempo, compor a sua base aliada com a oferta de cargos aos vereadores nos territórios. Contudo, na metade da gestão Pitta, o surgimento do escândalo da "máfia da propina" nas regionais, sobretudo envolvendo parlamentares governistas, estimulou o retorno da tese da descentralização ao debate público.

De modo geral, após mais de três décadas de implantação das Administrações Regionais, havia um consenso entre atores políticos de diversos matizes e entidades da sociedade que esse modelo de gestão se esgotara por duas razões. Administrativamente era incapaz de ofertar serviços públicos de forma mais eficaz, ágil e com menores custos às populações locais. Politicamente por essas terem se tornado feudos cativos de vereadores dos bairros e moeda de troca na obtenção de maiorias estáveis do Executivo, ademais de se ressentirem de controle social para fiscalizar o parlamentar e o administrador regional por ele indicado. Nesse contexto, a proposta das Subprefeituras passou a ser considerada uma solução necessária para modernizar a gestão da cidade de São Paulo e ganhou destaque nas eleições municipais em 2000. As Subprefeituras seriam capazes de responder positivamente ao estiolamento das antigas regionais e foram apresentadas como um eixo estratégico no programa da candidata Marta Suplicy para "dar início a uma nova ordem de coisas". Todavia, a implantação das Subprefeituras "foi difícil de executar" e a discussão de como ocorreu esse processo será o objeto dessa dissertação. Sobretudo, buscarei identificar as condições causais políticas e administrativas que influenciaram a trajetória e o formato que o modelo assumiu.

O objetivo da pesquisa consiste em analisar como a institucionalização das Subprefeituras serviu à estratégia de governo, considerando o contexto político e 
administrativo na qual se inseriram. Notadamente, busco identificar os atores políticos que, com seus interesses e recursos políticos, incidiram para a configuração que a descentralização tomou. Nesse sentido, pretendo analisar a forma como essa política foi constrangida pela prioridade do Executivo que era consolidar sua base de apoio parlamentar. Para atingir essa meta, o governo transformou as Subprefeituras no principal estímulo institucional a mediar sua relação com os vereadores do PT e demais partidos que passaram a formar a coalizão política dominante. Um dos efeitos dessa opção do governo foi a secundarização dos mecanismos de democracia participativa e de controle social, em especial aqueles relacionados às atividades dos vereadores. Além dessa orientação política que visava não comprometer a política de alianças, no plano interno, o governo enfrentou a oposição e resistência das Secretarias municipais temerosas de perder poder para as Subprefeituras. Em tese, a descentralização deveria reforçar a gestão dos territórios e reduzir o papel dos órgãos centrais. Tal processo de negociação, visando à transferência de atribuições e recursos, sobretudo financeiros para as localidades, foi desigual e irregular para cada política setorial. O principal efeito desse embate entre territórios e "governo central" gerou distintos ritmos, escopos e formas de descentralização, o que acabou criando um processo errático e sem capacidade de implantar um modelo coerente de uma "nova ordem de coisas" na gestão local.

Em face desse objetivo, o problema da pesquisa está organizado em torno de duas questões. A primeira trata de analisar se o projeto da descentralização possuía unidade interna no debate governamental. Tal questionamento é relevante, pois, desde o início, essa discussão evidenciou divergências que extrapolaram o consenso que parecia existir durante sua apresentação à sociedade na campanha eleitoral em 2000. Assim, é importante verificar de que forma a oposição interna de secretários temerosos de perder poder para as Subprefeituras acabou sendo uma variável organizacional e política que influiu no desenho da descentralização. E, de modo mais específico, as escolhas políticas do governo Marta Suplicy frente a esse conflito que ocorreu com as Secretarias municipais, visto que as Subprefeituras eram parte de um amplo projeto de reforma administrativa do Estado em nível local.

A segunda questão é verificar como as Subprefeituras serviram para o governo consolidar sua coalizão de apoio na Câmara Municipal de modo completamente distinto daquele apresentado na campanha eleitoral em 2000. Como a construção da governabilidade no parlamento adquiriu centralidade, é importante analisar como as Subprefeituras serviram de recurso político do Poder Executivo na barganha com os vereadores. A tese da candidata Marta Suplicy sobre o parlamento local como arena para debater os grandes temas da cidade, deixando a gestão dos territórios para as Subprefeituras, não foi a realidade. Assim, é 
importante analisar as razões que levaram o governo a alterar sua compreensão do papel dos vereadores na gestão dos territórios. E porque essa prioridade assumida pelo Executivo em definitivo retirou qualquer relevância política que pudesse ser assumida pelos mecanismos de democracia participativa na sua estratégia de governabilidade e de gestão das regiões.

Com base nesse problema de pesquisa, foram formuladas duas hipóteses de trabalho que convergem para o caráter errático da descentralização político-administrativa na cidade de São Paulo. A primeira compreende que a política de governo para as Subprefeituras, que foram inicialmente concebidas como núcleos locais de poder amparados no controle social, recuaram dessa intenção em favor da prioridade que assumiu a "lógica da vereança" nos territórios. Como as Subprefeituras passaram a alimentar a ampliação da política de alianças, a descentralização manteve a prática fisiológica de partilhar o poder cooptando vereadores que fora, na campanha eleitoral, criticada pelo PT como método malufista de construção de maiorias. Como efeito da prioridade que essa política assumiu, o governo recuou na implantação do Conselho de Representantes como instância de controle social e de fiscalização de Subprefeitos e vereadores. Agregue-se a isso, o papel secundário conferido ao Orçamento Participativo e aos movimentos sociais na coalizão política dominante.

A segunda hipótese entende que o governo, diante da resistência e oposição das Secretarias municipais, recuou das intenções iniciais do projeto das Subprefeituras como eixo central para a gestão das políticas públicas na cidade. De forma geral, a descentralização assumiu um caráter mais conservador em relação ao repasse de atividades e recursos dos órgãos centrais para as regiões. De maneira mais específica, a implantação das Subprefeituras acabou condicionada pelo nível de adesão de cada política setorial, o que gerou problemas para a produção e realização das ações integradas nos territórios, tal como era a intenção do modelo concebido pelo governo. Na prática, os arranjos políticos e administrativos entre as regiões e as Secretarias municipais, decorrentes dos atores políticos, seus interesses e recursos políticos, prevaleceram sobre um formato unificado de Subprefeituras junto ao Executivo.

Este desenho de pesquisa se torna importante, pois a ciência política brasileira pouco tem estudado a descentralização na gestão intra-municipal, sobretudo nas grandes cidades, e os impactos que produz no jogo político e administrativo local. A literatura que aborda o assunto se centra em analisá-la no contexto federativo das relações intergovernamentais e de assunção pelos municípios de políticas sociais como saúde, educação e assistência social. Sob esse enfoque o tema é discutido por autores como (Abrucio, 2005; Arretche, 1996; Souza, 2005; Nogueira, 1997; Affonso, 2000; Falleti, 2006) abordando a coordenação federativa e a relação do governo nacional com os municípios, (Arretche, 1999, 2002, 2004; Almeida (s/d); 
Souza 2004) tratando do federalismo e políticas sociais, (Afonso \& Araújo, 2000) analisam a capacidade financeira das cidades em suportar a descentralização das atribuições do governo federal, (Kugelmas e Sola, 1999; Almeida, 2005) discutem o rumo da descentralização ou recentralização de políticas públicas, (Mello, 1996; Souza, 2002, Souza e Carvalho, 1999; Souza e Blumn, 1999) debatem a descentralização, reforma do Estado e desigualdades intermunicipais que afetam a capacidade local para financiar e implantar políticas públicas. Mesmo autores que tratam da descentralização no plano municipal, como Farah (2006), a enxergam como apoio à democracia participativa e não como modelo político-administrativo.

A pesquisa acadêmica das experiências de descentralização, ou desconcentração, político-administrativa na gestão municipal, com seus impactos na organização do Estado em nível local, é reduzida ${ }^{1}$. Especialmente se o objetivo é analisar o jogo de poder e a ação dos atores políticos no interior das instituições políticas. Isto para não falar dos efeitos que tais empreendimentos podem trazer na oferta de serviços públicos ao cidadão. O estudo desse tema pode ser aprofundado pela ciência política, pois, conforme pode ser visto na tabela abaixo, ao menos as seguintes metrópoles brasileiras têm adotado seus modelos de descentralização/desconcentração territorial.

Tabela 1 - Descentralização/desconcentração administrativa em metrópoles brasileiras

\begin{tabular}{ccc}
\hline Localidade & Ano & Nome \\
\hline São Paulo & 1965 & Administrações Regionais \\
& 2002 & Subprefeituras \\
Salvador & 1983 & Administrações Regionais \\
Belo Horizonte & 1983 & Administrações Regionais \\
Curitiba & 1986 & Administrações Regionais \\
Vitória & 1986 & Gerências Regionais \\
Rio de Janeiro & 1993 & Subprefeituras \\
Fortaleza & 1997 & Secretarias Executivas Regionais \\
João Pessoa & 2008 & Subprefeituras \\
\hline
\end{tabular}

Fonte: elaboração própria

É nesse sentido, que a discussão da implantação das Subprefeituras na cidade de São Paulo se insere, visando analisar o que ocorreu quando o Executivo propôs "um novo estado de coisas" para a gestão municipal. Desde a década de 60 já existiam as administrações regionais que organizacionalmente serviam para desconcentrar serviços e politicamente eram

\footnotetext{
${ }^{1}$ Com esse enfoque, encontrei apenas o estudo de LAMEIRÃO, C.R. Estratégias políticas e gestão local: as subprefeituras do município do Rio de Janeiro [Dissertação]. Rio de Janeiro: Instituto de Ciências Humanas e Filosofia: Universidade Federal Fluminense; 2007. Boschi (1998), de forma distinta, no artigo Governança, Participação e Eficiência das Políticas Públicas: Exame de Experiências Municipais no Brasil trata dos casos de Salvador e Belo Horizonte ao associar descentralização com instâncias de democracia participativa.
} 
funcionais para os governos comporem sua a base de apoio parlamentar, sobretudo após 1985 . Tais antecedentes da descentralização influíram na política adotada pelo governo petista, especialmente a relação com os vereadores, que se pautou pela mesma lógica fisiológica das administrações anteriores nos territórios. Assim, se as Subprefeituras eram uma novidade, também carregaram a herança de uma lógica prevalecente na política municipal que servia para orientar o cálculo político dos governos na construção de suas coalizões de apoio.

Deste modo, estudar as Subprefeituras no governo petista na cidade de São Paulo busca contribuir para o debate da descentralização como forma de organizar política e administrativamente o Estado em nível municipal. Pesquisas similares em outras metrópoles também poderiam desnudar as contradições, impasses e dificuldades nas iniciativas de descentralização, a exemplo dessa dissertação. Especialmente identificar os atores políticos que, com seus interesses e recursos políticos, influenciam o contorno dos processos de reforma do poder público na gestão intra-municipal. Este enfoque se afasta daqueles que veem a mudança institucional nos governos locais sem considerar a dinâmica do poder e da luta política, com destaque para duas abordagens. Para Castells \& Borja (1996), as cidades são atores políticos com capacidade para mobilizar o apoio consensual de grupos políticos no governo e na sociedade visando definir suas prioridades estratégicas. Já para Osborne (1998), com base nas experiências de municípios americanos, a ênfase recai sobre a capacidade empreendedora do governo local para transformar o setor público, inovar a gestão e ampliar sua eficiência administrativa. Em tais concepções, o governo local é tratado como uma unidade sem contradições internas, pois não se analisam as disputas dos atores políticos em torno da partilha de poder quando se altera a configuração organizacional. Ou o governo é visto como uma entidade que promove acordos em torno de um estratégico Projeto de Cidade, ou é visto como empreendedor de mudanças administrativas. Tais visões abstraem a luta política no interior dos governos, pois as mudanças institucionais alteram a partilha de poder e a relação com os atores políticos, como ocorreu na descentralização realizada na cidade de São Paulo. Processos dessa ordem, por envolverem atores políticos e seus interesses, não são consensuais ou tecnicamente neutros, além de dependerem da contingência da política.

Para os fins da pesquisa, que objetiva desnudar os atores políticos, seus interesses e recursos políticos utilizados na implantação das Subprefeituras, a opção metodológica foi a análise qualitativa e o estudo de caso. Entendo que, dessa forma, se pode compreender e interpretar melhor as distintas realidades e configurações políticas e institucionais que a descentralização assumiu nos territórios da cidade. Na seção seguinte se apresentam as referências metodológicas que embasaram a pesquisa para essa dissertação. 


\section{Subprefeituras: casos singulares, mas no contexto geral da descentralização}

Segundo o método de pesquisa comparada, proposto por Ragin (1987), a análise qualitativa deve se orientar para casos historicamente localizados. Esta metodologia permite comparar fenômenos mais estreitamente definidos, de modo que exemplos relevantes podem ser examinados a partir de uma configuração de condições presentes em um contexto. Assim, o escrutínio da realidade pode revelar as conexões empíricas e as bases sociais de eventos específicos. Este tipo de análise, portanto, é sensível à complexidade e especificidade histórica e seus resultados são usados para gerar esquemas conceituais onde há a ação humana em questões de natureza social e política. Com essas características, os estudos de caso permitem qualificar a análise contextual, sobretudo suas causas que são mais bem compreendidas nessa totalidade conjuntural. Segundo Ragin (1987: 3), casos são configurações de características historicamente interpretadas para

Explicar resultados históricos específicos ou conjunto de resultados comparáveis, ou processos escolhidos para serem estudados por causa de seu significado para os arranjos institucionais ou para a vida social em geral.

Da mesma forma, os resultados são analisados a partir da interconexão das condições, o que facilita interpretar os casos historicamente. Desse modo, é possível identificar que, em contextos específicos, diferentes condições causais se combinam em distintos e contraditórios modos para produzir resultados similares. A análise contextual possibilita aproximar a complexidade, a diversidade e a singularidade das unidades sociais em análise, e permite simplificar a interpretação ao examinar similaridades e diferenças entre um número limitado de casos. Com esta orientação, o pesquisador pode adotar uma estratégia comparativa que deve ser holística (para não perder os casos considerados como totalidades significativas) e analítica (para comparar poucos casos em modestas generalizações sobre resultados e sua origem histórica). Portanto, mesmo havendo certa indeterminação pela pouca variedade de casos, o pesquisador pode identificar regularidades empíricas nas comparações, avaliar e interpretar casos relativos a critérios teóricos e gerar evidências qualitativas.

Segundo o autor, o estudo de casos permite reunir evidências sensíveis à cronologia dos fatos para melhor conhecer a trajetória de eventos significativos e suas causalidades. Para tanto, o uso de categorias mais amplas nas explicações, como partidos ou entidades políticas, são importantes quando se comparam os casos. Com este recurso metodológico se pode conhecer diferentes condições ou causas contextuais, além de sua verificação em outra situação, de modo que se pode analisar cada caso como uma combinação das partes de um todo. Pode-se, assim, encontrar as condições causais convergentes que, reunidas ou 
combinadas de certo modo, inserem uma análise individual em uma configuração mais ampla. A associação observada com as causas visa conhecer os resultados específicos e examinar as similaridades e diferenças entre exemplos relevantes e elucidar os seus porquês. Agindo dessa forma, o pesquisador busca descortinar os padrões de invariância e associação constante entre causa e efeito. Os estudos comparativos de casos não explicam variações, mas diferenças entre exemplos de um resultado ou o desenvolvimento de distinções entre subtipos de um fenômeno. Isto foi o que ocorreu com distintas formas de partilha de poder nas Subprefeituras que serão caracterizadas, após a análise dos casos, na conclusão desse texto.

Conforme essas premissas, uma das formas para se utilizar a metodologia apresenta três passos básicos: a) a procurar similaridades e resultados comuns entre unidades de um conjunto; b) demonstrar se tais semelhanças são causalmente relevantes para o fenômeno e; c) com base em tais similaridades o pesquisador formula uma explicação geral. Este método é dedutivo, pois noções teóricas iniciais servem de guia para examinar causalidades relevantes das similaridades e diferenças. E é indutivo porque o investigador determina quais teoricamente relevantes semelhanças e distinções são operacionais para análise empírica dos casos. Após essa fase o pesquisador formula uma explicação geral, com base nas similaridades e diferenças identificadas, e a indução culmina na elaboração das ideias teóricas iniciais, o que possibilita ao método comparado disseminar conhecimento social.

As formulações de Tilly (1983), ao apresentar as vantagens da metodologia da análise dos casos e sua posterior generalização, são similares às de Ragin (1987). O ponto de partida reside em especificar para quais unidades o exame do investigador se dirige. Isto porque, ao se realizar comparações entre os casos, qualifica-se a possibilidade de se estabelecer o princípio da variação ou a intensidade de um fenômeno pelo escrutínio das diferenças entre os exemplos. A generalização também permite o reconhecimento da singularidade dos casos individuais, a despeito da inter-relação causal entre eles. Mas, deve-se evitar o particularismo da análise que não permite testar a validade de pressupostos teóricos apoiada em proposições explicativas gerais. Sobretudo, é difícil avaliar o impacto efetivo dos casos sem se analisar os atores políticos e suas crenças no interior de históricas "circunstâncias estruturais". Portanto, o caminho para a generalização analítica deve partir de unidades sociais específicas, e dos atores políticos que atuam nesse contexto, visando identificar suas similaridades e diferenças.

Este caminho metodológico permite constatar as diferenças e variações entre os exemplos de um fenômeno, sem prejuízo de convertê-las em generalizações experimentais. Segundo o autor, o enfoque contextual deve considerar um "na medida em que" certos fatores estão presentes, visando configurar as semelhanças ou distinções para que seja possível se 
produzir a generalização dos casos. A vantagem desse tipo de comparação, portanto, consiste em produzir um princípio que prontamente se estende para outros casos, sendo relativamente fácil de verificar ou modificar sobre a base de novas evidências. De forma mais específica, as regras para uma efetiva comparação generalizante, segundo Tilly (1983: 96), são:

1) specify your arguments; 2) observe units that correspond to the units of your argument; 3) make sure your units are comparable with respect to the terms of your argument; 4) either observe units you can reasonably consider to be independent of each other, or make specific allowance for their interdependence in the specification of the argument and the analysis of the evidence; 5) make your measures correspond closely to the terms of your argument; 6) either have all your measures pertain to the same level of aggregation, or subdivide argument and analysis by levels of aggregation; 7) when a significant element of judgment enters the coding of evidence, do the coding yourself or test its reliability with great care; 8) minimize and delay the reduction of detail to abstract categories; if possible, make that reduction part of the analysis itself; 9) adopt or devise models corresponding closely to the logic of your argument.

Embora o autor alerte que, em face do pequeno número de casos, o pesquisador corre o risco de prestar pouca atenção para circunstâncias históricas e às condições de uma efetiva comparação. Uma forma de minimizar esse limite consiste em se realizar uma análise "genuinamente histórica" que assuma o tempo e o lugar em que uma estrutura ou processo parece fazer uma diferença para as suas características. Isto de um modo onde a sequência em que eventos similares ocorrem tem um substancial impacto nos resultados do contexto, o que requer investigação sistemática, ao invés de se produzir imediatas sínteses pouco embasadas. As generalizações, quando são realizadas diante dos graus distintos de manifestação de um fenômeno, qualificam as comparações, mesmo que cada caso seja um exemplo independente. Isto porque os diferentes casos resultam das distintas combinações de "variáveis" e condições causais que geram efeitos específicos, sobretudo, as escolhas de atores políticos que em um dado ponto no tempo constrangem possíveis resultados em momentos posteriores.

Com base nessas considerações metodológicas, a pesquisa analisou dois distintos casos de descentralização (Capela do Socorro na zona sul e Freguesia do Ó na zona norte) do mesmo fenômeno (a implantação das Subprefeituras na cidade de São Paulo). A justificativa da escolha das regiões selecionadas se deve ao fato de representarem variantes bem definidas de partilha de poder nas regiões. Quando comparadas, Capela do Socorro e Freguesia do Ó apresentam agudos contrastes políticos e administrativos, além de similaridades na sua configuração institucional. Assim, a análise de ambos os casos permite encontrar as condições invariantes que, a despeito de gerarem diferenças na partilha do poder em cada local, produziram resultados semelhantes nas duas Subprefeituras. Esta situação permite algumas generalizações da descentralização municipal que serão discutidas na conclusão do trabalho. 
Contudo, registre-se o limite desse estudo, pois os casos analisados, e as hipóteses de trabalho, não permitem conclusões definitivas diante da existência de 31 Subprefeituras e das distintas configurações políticas e administrativas que ocorreram em cada região.

Para a pesquisa foram realizadas 19 entrevistas (oito em cada uma das duas Subprefeituras, priorizando o Subprefeito e os coordenadores setoriais, conforme o organograma apresentado no capítulo um). Além desses, foram entrevistados o Chefe de Gabinete da Secretaria de Governo Municipal, o Coordenador Municipal do Orçamento Participativo e a Secretária Municipal de Assistência Social, ex-Secretária das Administrações Regionais da gestão Luiza Erundina (1989-1992). Esta base de dados primários foi importante para confrontar a realidade política e administrativa em cada Subprefeitura, tanto no geral como nas políticas setoriais descentralizadas. Também foi realizada a pesquisa de fontes secundárias na documentação legal (leis, decretos e portarias) que embasou a implantação das Subprefeituras. Para completar o levantamento de informações, foram analisados textos governamentais sobre o tema e realizado um estudo hemerotécnico em notícias e matérias jornalísticas (Folha de São Paulo e O Estado de São Paulo) entre 2001 e 2005.

A dissertação está organizada da seguinte forma. No capítulo um, e coerente com a metodologia para o estudo de casos, se discutem os argumentos teóricos para tratar do objeto da pesquisa. Nesse sentido, o apoio na literatura sobre o Estado e os atores políticos é útil, para se analisar como a implantação de uma política pelo governo municipal fez os grupos localizados na máquina administrativa e no parlamento se mobilizarem para garantir seu espaço de poder. Mas uma nova política, ao produzir alterações no desenho institucional, se defronta com o legado histórico de formas preexistentes de prática política que constrange as iniciativas de mudança que o Estado visa implantar. De outro lado, o próprio governo, ao intervir como ator político, acaba fortalecendo a cultura política existente ao se valer da manutenção práticas políticas prevalecentes para tais atingir seus objetivos.

O capítulo dois discute a implantação das Subprefeituras na gestão Marta Suplicy (2001-2004). O argumento central é que administrativamente a descentralização foi errática e que politicamente o governo não priorizou, nas regiões, os mecanismos de democracia participativa. Na primeira questão, se analisa a resistência das Secretarias municipais em delegar atividades às regiões, cujo efeito se traduziu nas distintas configurações que as Subprefeituras assumiram em cada localidade. Especialmente, a inexistência da gestão intersetorial de políticas. Em relação à segunda questão, se discute que governo recuou na implantação de mecanismos de democracia participativa nos territórios, a despeito do funcionamento do Orçamento Participativo. O argumento central é que o governo priorizou 
construir sua política de alianças junto aos vereadores por considerá-la mais estratégica para a governabilidade.

O capítulo três trata do caso da Freguesia do Ó e os efeitos para a gestão local quando o comando petista da Subprefeitura foi alterado após o Executivo incluí-la na negociação com os vereadores para compor sua coalizão de apoio na Câmara Municipal. O novo grupo dirigente era formado por vereadores malufistas, embora o PT se mantivesse a frente de certas políticas. A falta de diálogo entre esses dois campos políticos condicionou as características da descentralização do ponto de vista político, em face da perda de hegemonia petista; e administrativo, como efeito da ruptura e descontinuidade com o modelo de gestão em vigor. O capítulo quatro analisa a Subprefeitura da Capela do Socorro e a manutenção da sua direção política sob a hegemonia da família Tatto, grupo petista na região. Tal situação ampliou a resistências das Secretarias municipais receosas de perder espaço para esse grupo. Nessa região, politicamente houve a manutenção da hegemonia petista e administrativamente a descentralização se caracterizou por uma maior continuidade. Em ambos os casos, mesmo existindo mecanismos participativos estes, por razões distintas, não se consolidaram como instrumentos centrais na gestão no território. Nas duas regiões, o que preponderou foi a influência dos parlamentares para partilhar o poder nas Subprefeituras. Esta prática ocorreu em todos os partidos políticos, sobretudo no PT como partido majoritário da coalizão de governo. Assim, ao invés da ênfase na democracia participativa, o Executivo priorizou a participação dos vereadores na gestão dos territórios.

Na conclusão do trabalho cotejo a discussão teórica com os casos analisados para, com base nas duas hipóteses da pesquisa, propor algumas generalizações sobre o fenômeno em questão: a implantação das Subprefeituras. São conclusões preliminares que buscam indicar as configurações políticas e institucionais que a descentralização assumiu na cidade de São Paulo, e que podem ser úteis para pesquisas em outros contextos distintos. Por fim, se lançam algumas questões que podem orientar novos estudos, considerando as mudanças políticas e administrativas que as Subprefeituras sofreram nos governos posteriores de José Serra (PSDB) entre 2005/2006 e Gilberto Kassab (DEM) de 2006 até o presente momento. 


\section{ATORES POLÍTICOS E SUAS ESTRATÉGIAS EM CONTEXTOS DE MUDANÇA POLÍTICA E ADMINISTRATIVA}

Esta dissertação estuda a implantação das Subprefeituras na cidade de São Paulo entre 2001 e 2004 e, em termos teóricos mais amplos, está interessada em analisar como atores políticos agem em contextos de mudança institucional, como foi o caso da descentralização promovida pelo governo Marta Suplicy. Assim, como uma política que visou alterar o desenho político e administrativo da cidade serviu para acomodar os interesses de alguns atores políticos, ao mesmo tempo em que gerou a oposição e resistência de outros atores? Quais os impactos que as alterações organizacionais e o realinhamento de relações de poder geraram para a gestão das políticas públicas? Qual a capacidade de o Estado alterar o sistema político e administrativo em face dos constrangimentos políticos e institucionais à ação dos atores políticos? Como o governo definiu sua estratégia política nesse processo de mudança institucional? Como objetivos previstos para uma política, quando são modificados, afetam a sua evolução institucional e criam constrangimentos para sua implantação?

Para analisar essas perguntas, o problema e as hipóteses da pesquisa, será apresentado o enfoque teórico que foi adotado. Na primeira parte do texto se discutem as correntes teóricas que abordam a relação entre atores políticos e o Estado. O debate inicial será sobre a teoria das elites e o pluralismo, a forma como concebem a ação dos atores políticos e seus reflexos na estrutura de poder da cidade. Na segunda parte do texto se aborda o institucionalismo histórico e o argumento de que as instituições fornecem o contexto para a atuação dos atores políticos na definição de suas estratégias. Conforme essa abordagem as políticas dos governos, por serem influenciadas e dependentes da trajetória histórica, a despeito de suas intenções inovadoras, acabam por limitar suas possibilidades e capacidade de mudança. Por tal razão, as instituições políticas são importantes de serem analisadas para identificar como condicionam e constrangem a ação dos atores políticos.

\subsection{ATORES POLÍTICOS E A DINÂMICA POLÍTICA DOS GOVERNOS LOCAIS}

$\mathrm{Na}$ abordagem clássica da teoria das elites, conforme Hunter (1973), os líderes econômicos são o topo de uma estrutura de poder dominante e estável na política municipal em que poucos "homens de decisão independente" comandam os "executores das políticas". Para o autor, na análise da vida política municipal deve-se saber quem são os líderes econômicos proeminentes, visto que o governo tem sua dinâmica determinada pelos interesses 
desses atores que, de fato, são os produtores de políticas. O poder dessas elites não só lhes permite atuar em separado da sociedade, mas também constrangem o governo aos seus objetivos como se fossem de interesse coletivo. O governo seria funcional para sustentar o poder dos líderes econômicos e um ator político sem recursos políticos para arquitetar seu projeto de poder, pois a vida cívica na cidade é comandada pelos empresários. Ademais, a política municipal não demandaria negociações entre o Poder Executivo e o Legislativo, pois ambos são considerados atores políticos subordinados ao domínio das elites econômicas. Tal barganha, além de contraproducente, é contornada por "comitês cívicos" cuja função reside em implantar as iniciativas dos líderes empresariais.

Estes comitês organizam uma pirâmide de poder voltada a atender os interesses das elites econômicas e possuem quatro níveis hierárquicos que distinguem os "iniciadores" de políticas dos “implementadores”. No primeiro nível estão os grandes empresários; no segundo os altos executivos públicos e privados; no terceiro, as organizações cívicas e gestores privados e públicos de nível médio e; no quarto, professores, trabalhadores sociais e gerentes de pequenos negócios. Com esta estrutura de poder as elites econômicas buscam proteger-se de demandas contrárias aos seus interesses. Assim, a formação de coalizões de governo passa ao largo da disputa política entre os partidos e seus representantes, como é caso dos vereadores. Os "nós de interesse" empresariais organizam "pequenos círculos compactos" decisórios que prescindem de partidos políticos e do parlamento para aprovar políticas.

É nesse sentido que, para Hunter (1973), inexiste a disputa pelo poder, pois a dominação no sistema político já está definida a priori e sem controvérsia. Nas cidades, mais ainda essa estrutura de poder se identifica com as "igrejinhas" dominantes que decidem políticas e rebaixam os políticos partidários aos níveis médios de poder sem capacidade de decidirem sobre a produção de políticas (MILLS, 1968). Para Hunter (1973), o poder legislativo é um subproduto da fraqueza da máquina pública permeável aos interesses econômicos. Além disso, a supremacia do Executivo é mais um fator que reduz o Legislativo a representante de localidades e interesses específicos, já que, para Mills (1968: 317),

A burocracia executiva se torna não só o centro de poder, mas também a arena dentro
da qual e em termos da qual todos os conflitos de poder são resolvidos, ou negam-se
soluções a eles. A administração substitui a política eleitoreira; as manobras
substituem os choques dos partidos.

Esta "burocratização e centralização da política" seria um substituto à barganha que existe na construção de coalizões partidárias de apoio ao governo. Tal tendência se consolida quando os políticos profissionais buscam ganhar poder, segundo Mills (1968: 306:307), 
[...] nas ações dos grupos, dentro e entre as repartições mais ou menos burocráticas da administração. Cada vez mais, o politico profissional procura conjugar-se com o administrador que chefia um departamento, uma comissão ou uma repartição, a fim de exercer o poder com ele, contra outros administradores e políticos [...]. A distinção tradicional entre "legislação", como elaboração de política, e "administração", como sua realização, desapareceu de ambos os lados.

A participação que o político tem na orientação do Estado se faz menos pelo seu voto contra ou favor de uma lei do que pela sua participação num grupo que esteja em condições de influenciar os postos de comando da administração executiva [...].

Para a pesquisa, essa tendência ao "governismo" na atividade parlamentar que busca se aproximar das funções de gestão pública, conforme destacado por Mills, é útil para compreender um dos fatores que influenciou a partilha das Subprefeituras entre os vereadores na cidade de São Paulo. De outro lado, a abordagem de Mills destaca a preeminência do Executivo como ator político que dispõe de recursos políticos para cooptar parlamentares ao ofertar cargos no governo. Desse modo, na construção da coalizão política dominante do governo Marta Suplicy, os vereadores foram considerados atores políticos centrais para a governabilidade, em oposição ao enfoque da teoria das elites sobre a secundarização do parlamento. Ou seja, a relevância do Legislativo não decorre de sua posição estrutural na sociedade, mas do lugar que ocupa na configuração política e institucional junto ao poder Executivo. Antes de ser uma elite com valores comuns, os vereadores defendem seus interesses, no contexto da democracia representativa, visando aumentar sua influência sobre o governo, como ocorreu na construção da coalizão de governo em São Paulo. Contudo, a teoria não descreve como se produzem esses acordos e a barganha nele inserida, nem o porquê do Executivo franquear a participação desses "políticos profissionais" no governo.

A teoria das elites também não analisa a organização e a divisão política da máquina governamental como resultado da partilha de poder entre grupos políticos. O governo é tratado como um bloco homogêneo a serviço das "igrejinhas" econômicas dominantes na cidade, o que torna desnecessário negociar o apoio das facções políticas internas. Contudo, a visão de interesses econômicos que limitam as políticas públicas a seus fins é pouco plausível, a não ser que toda direção política governamental seja nomeada por líderes empresariais. Esta questão não é abordada por Hunter (1973), mas a resposta é que as elites dominantes têm vínculos privilegiados e não transparentes com a alta burocracia pública para tratar de seus interesses. Com isso, a teoria não analisa as contradições internas do governo local na implantação de políticas, como foi o caso das Subprefeituras, que desorganizam a divisão de poder existente no nível central da administração municipal. Ainda assim, a crítica de Mills sobre a máquina pública funcionar como um sistema de proteção aos partidos, que se vale dos empregos para gerar compensações, é útil para a pesquisa. Na implantação das Subprefeituras, 
os acordos do Executivo com os vereadores de todos os partidos possibilitou a esses realizarem indicações de cargos. Houve o que Hunter chama de "aspectos privados do poder", válido para verificar o porquê do interesse dos vereadores em indicar Subprefeitos. Contudo, essa abordagem carece de recursos analíticos quando se busca identificar os atores no interior da estrutura governamental e seus interesses em processos de mudança institucional.

Sob outro enfoque, Davis (1993), ao estudar Los Angeles, compreende as elites como "linhagens de poder" que, mesmo alterando seu perfil socioeconômico e composição interna, historicamente dominam a política local. Inserindo a análise em uma moldura histórica, o autor expande a tese de Hunter e Mills do poder político como tradução direta da estrutura social. Segundo Marques (2003), Davis visa identificar as continuidades na estrutura do poder local, mas enfatiza que o jogo político é mais complexo do que afirmar que só uma elite domina o governo. Para Davis, existe a contingência e o conflito na política, ainda que limitados às disputas intra-elites e sem alterar a dominação estrutural. Isto porque as "classes altas" possuem recursos políticos para manter o sistema de poder local junto a todos os partidos políticos ${ }^{2}$. Assim, mesmo existindo alternância de poder, a luta política é um jogo de soma zero, pois a vitória eleitoral de um bloco exclui o outro do governo.

Para essa pesquisa, o argumento de Davis tem limites em compreender a relação entre o governo municipal e os atores políticos na sociedade e no parlamento local. O poder público é visto com um ator que age de forma reativa ou proativa frente aos interesses econômicos dominantes e reprime a oposição à hegemonia política das elites. Mas, a implantação de processos participativos direcionados aos movimentos sociais de bairro, como ocorreu em São Paulo, se voltou para atores políticos que não podem ser considerados da elite política municipal. Nestes mecanismos de participação o que houve foi a interferência dos vereadores junto às entidades locais, notadamente do PT, visando transformar tais fóruns em meios de ampliar a hegemonia política junto a esses setores. Assim, ao menos formalmente, o governo buscou estender a política além da democracia representativa sem a intenção de conter os conflitos entre os interesses estruturalmente coincidentes das "classes altas".

O jogo de poder não resultou em soma zero na relação do governo com a Câmara de Vereadores na cidade de São Paulo. A vitória eleitoral do PT não alijou vereadores que participaram de outras gestões, pois o Executivo priorizou a construção da política de alianças sob a tese do "governo amplo". Assim, o permanente alinhamento e influência dos vereadores

\footnotetext{
${ }^{2}$ Para o autor, o mais poderoso "movimento social” em Los Angeles são os proprietários residenciais influentes. Este é o "povo" organizado para defender o "poder dos bairros" que exemplifica o controle estrutural sobre o governo. Já os trabalhadores são subordinados, pois "a maioria silenciosa de proprietários residenciais nãoafluentes e inquilinos continuaram a ser meros peões nas lutas pelo poder...”(DAVIS, 1993: 196).
} 
na base aliada dos governos, independentemente de partido político, é um traço importante da política municipal intensificado desde a gestão Jânio Quadros (1985-1988). Ainda para Davis, o parlamento é uma instituição subserviente aos interesses das elites dominantes, especialmente da especulação imobiliária, e os vereadores são atores sem interesses políticos próprios. Mas a despeito da intenção do Executivo municipal de consolidar seu bloco de apoio, os vereadores nem sempre concordaram, como ocorreu no debate sobre a criação do Conselho de Representantes. Desse modo, a descrição que Davis faz da oposição dos vereadores em Los Angeles aos "Conselhos de Planejamento dos Cidadãos" mostra como esses não são atores políticos secundários no contexto local. E que o Executivo, mesmo que construa sua politica de alianças cooptando os vereadores, recua ou altera projetos quando a prioridade é manter estável a sua coalizão política dominante.

O poder local é visto de forma distinta pelo pluralismo, pois a política não é analisada pelo enfoque de elites que, dada sua proeminência na sociedade, seriam o único estrato com recursos políticos a lhes garantir hegemonia política sobre os governos. Para o pluralismo, a dinâmica da política e do poder busca conhecer, nas "áreas em questão" (issue areas), como os atores políticos agem, quais os seus interesses e os recursos políticos que possuem. Por esta razão, este arcabouço analítico é mais apropriado para essa pesquisa. Sobretudo, para compreender como o Executivo tratou suas clivagens internas setoriais e como conformou sua política de alianças junto aos vereadores ao negociar sua participação nas Subprefeituras.

Segundo essa teoria, a sociedade é formada por uma diversidade de interesses que dispersa recursos políticos entre os atores políticos. Por isso a política é exercida desigualmente quando os atores defendem seus interesses visando que o governo os incorpore (Dahl, 1958, 1989; Polsby, 1960). Nos "temas chave" de política existem arenas decisórias específicas com diferentes atores, interesses e recursos políticos a gerarem coalizões de políticas que distribuem poder e permitem explicar as decisões governamentais. Contudo, o governo local é um ator político que dispõe de recursos e autonomia de ação para decidir sobre políticas, mesmo as que afetem líderes empresariais, como taxar impostos. Isto porque suas ações apelam antes para seus interesses eleitorais do que para o poder estrutural desse segmento. O Executivo local também pode conflitar-se com os grupos de interesse e não ser um refém desses, pois, para Dahl (1989), o seu incentivo central é assegurar sua reeleição.

Apesar de a democracia pluralista ser aberta à entrada de diversos atores com seus recursos políticos, isso não significa igualdade política. Os grupos políticos à frente do Executivo, por exemplo, dispõem de capacidades desiguais para incidir no jogo político, pois a vitória eleitoral lhes permite o controle de recursos políticos, como nomear cargos, gerar 
contratos e distribuir empregos, que influenciam as políticas públicas. Estes são recursos políticos centrais para forjar acordos mais estáveis diante da volatilidade dos interesses em disputa, pois a política não garante alianças entre os atores que não sejam efêmeras e conjunturais para o exercício do poder (DAHL, 1989, 1961; POLSBY, 1960). A partilha de cargos nas Subprefeituras foi chave para o Executivo municipal em São Paulo visando ampliar sua coalizão de apoio no parlamento. Também possibilitou a convivência das overt policies (políticas tornadas públicas como a descentralização da gestão territorial) com as covert policies (a inserção das Subprefeituras na barganha da política de alianças não se tornou pública, pois exporia a criticada prática malufista de negociação com os vereadores).

A esse respeito, segundo Bachrach \& Baratz (1962: 948), o exercício do "poder pode ser e, frequentemente é, exercido pelo confinamento do escopo da tomada de decisão para questões relativamente "seguras"”. Por tal razão, existem "duas faces do poder": uma é observável e possui decisões abertas; a outra se identifica quando um ator político dispõe de recursos para opor-se a uma política que sequer integra uma arena decisória. O governo pode delimitar sua agenda de políticas com a "mobilização do viés" que "filtra" os temas do debate político para evitar controvérsias indesejadas. Por exemplo, a política de desenvolvimento urbano em New Haven teve uma face observável com suas decisões abertas adotadas pelo Prefeito, mas escondeu os acordos prévios para que fosse aceita pelos atores políticos. $\mathrm{Na}$ implantação das Subprefeituras tal processo ocorreu, pois o Executivo acabou restringindo o debate e o escopo do projeto, se considerado o que se propunha inicialmente; sobretudo, em face das resistências dos grupos políticos internos do PT. Também transformou a descentralização em um processo que não conflitou com os interesses dos vereadores nos territórios ao recuar na implantação do Conselho de Representantes. Ao atuar dessa forma, o governo se pautou pelo que esses atores políticos consideravam relevantes aos seus interesses.

É nesse sentido que se deve "reconstruir as decisões importantes" adotadas pelos atores políticos nas "áreas em questão" para identificar quem inicia e produz as políticas, e quem tem poder de veto, visando se conhecer os interesses em jogo. Conforme Dahl (1989: 126), existem três tarefas inter-relacionadas para o governo formular e executar políticas: a) definir a direção da política para determinar o que será enfatizado e quanto de recurso será investido; b) desenvolver propostas específicas e negociar acordos em torno delas; c) realizar as políticas quando se obteve suficiente acordo na negociação. Assim, em cada política do governo, podem-se analisar os atores (por exemplo, grupos governamentais ou vereadores), seus interesses e recursos políticos que buscam opor-se ou apoiar as iniciativas. 
É a política com seus recursos de barganha, redução de conflito e construção de consenso, que organiza as relações entre os atores políticos. Sobretudo, porque os recursos políticos desiguais e dispersos entre vários atores fazem disso uma característica intrínseca do sistema político. Por exemplo, o controle dos empregos públicos municipais é uma "arma política regular" para alocar os trabalhadores do partido que governa. Mas o mais importante uso político de tais empregos é criar uma flexível Câmara de Vereadores (Board of Aldermen). Quando a administração municipal necessita de votos não reluta em estender seus favores ao parlamento com a política de "cenoura e porrete" (carrot and stick). Isto porque, ainda que a maioria dos vereadores vote favoravelmente ao governo, e contra suas convicções privadas, o fazem temendo perder seus atuais e futuros benefícios que são sempre relembrados pelo porta-voz do governo nas votações cruciais (DAHL, 1989). Na cidade de São Paulo, os vereadores nem sempre votaram contra suas convicções privadas, o que aumentou o custo político e o tempo de negociação em temas de interesse do governo. Bem como houve impasses em projetos que contrariavam os interesses dos vereadores no sistema político, tal como o controle social de suas atividades pelo Conselho de Representantes.

O controle que o governo tem dos empregos públicos é um exemplo da desigualdade de recursos políticos na sua relação com os vereadores. Por isso, para Dahl (1989: 126), o governo é um ator central para propor políticas, considerando que

Toda a administração assume uma postura que fornece aos participantes dicas sobre
quais tipos de políticas são mais prováveis de serem apoiadas, ou não, e quanto de
recursos em energia, tempo, habilidade e dinheiro são prováveis de estarem
disponíveis para diferentes políticas [...]. Se escolas são tratadas como uma área
favorecida, ou contratos de trabalhos públicos [...], o tema é logo conhecido para todos
aqueles que necessitam calcular o que é mais provável ou menos provável a fazer de
acordo com seus próprios desejos e esperanças.

Quando o governo explicita seus objetivos políticos se cria uma "área em questão" que permite aos atores políticos adaptarem suas estratégias. As alianças que se formam para sustentar tal prioridade de governo podem ser bastante heterogêneas e envolver "estranhas coalizões como nunca houve". O prefeito mobiliza apoio, mesmo oriundo de partidos políticos de oposição, e costuma obter aquiescência sem sérios e prolongados conflitos. Contudo, ao atender tantos interesses, o governo está consciente dos limites das políticas que inicia junto aos atores que participam dos debates. Conforme Dahl (1989), a política de desenvolvimento urbano do Prefeito Lee foi proposta para que fosse aceita pelos integrantes do Comitê de Ação Cívica em New Haven. Na criação das Subprefeituras na cidade de São Paulo, o Executivo atuou dessa forma para obter o apoio dos vereadores e dos grupos dirigentes das Secretarias municipais. No entanto, a relação desses órgãos centrais com as 
Subprefeituras esteve mais próxima do que Dahl (1989) chama de "pequenas soberanias": áreas controladas por diferentes líderes e que possuem seus objetivos, estratégias e interesses. Como a descentralização implicava perda de poder das Secretarias este conflito foi inevitável, pois "o ganho para um significava uma perda equivalente para o outro", e dificultou desmontar os acordos políticos de partilha de poder previamente realizados. Como resultado, a coordenação dessa política ficou prejudicada diante dos interesses desses grupos internos.

Para construir um padrão de coordenação de políticas e de liderança política o governo tem como alternativa implantar uma "coalizão centrada no executivo". Nesse modelo de "coalizão de coalizões", o Prefeito é o ponto focal e de intersecção das negociações para integrar políticas e atores políticos. Mas embora o prefeito possa ser influente em várias áreas, este arranjo não é hierárquico. A coalizão não é monolítica, enfrenta contestação interna sobre sua autoridade, pode ser afetada por ambíguas relações de influência e está sujeita à negociação e barganha dos atores políticos. Nessa coalizão, o prefeito não pode mandar e por isso barganha, apela, promete e demanda suporte de outros líderes. Uma forma de o Prefeito ampliar sua autoridade política é gerar uma política pública de impacto na cidade para fortalecer sua base de apoio. Também para reduzir atritos internos na coalizão o governo realiza indicações, constrói lealdades e dependências em áreas onde sua liderança é mais fraca (DAHL 1989) ${ }^{3}$. O debate na política educacional em New Haven mostra como o governo nem sempre confere inequívoco suporte aos membros de sua coalizão original, com base em um cálculo político sobre quando e como apoiar tais aliados em função de objetivos maiores. No caso, o prefeito Lee buscava ampliar sua hegemonia sobre um público mais amplo, tendo em vista as próximas eleições municipais. Em São Paulo, o Executivo se deparou com todas essas situações para implantar as Subprefeituras, que serviram para partilha de poder entre um leque mais amplo de partidos que apenas os grupos internos do PT, pois o objetivo estratégico era ampliar e consolidar a política de alianças e a governabilidade no parlamento.

O governo municipal pode ainda, para garantir apoio às suas políticas, “deliberadamente criar" a participação dos cidadãos nos "negócios públicos", como foi o Comitê de Ação dos Cidadãos (CAC) para referendar a política de desenvolvimento urbano em New Haven. Ao instituir tais arenas de políticas, o governo se antecipa e/ou estimula os

\footnotetext{
${ }^{3}$ Segundo Lowi (1964), para o pluralismo as coalizões se formam em torno de "interesses compartilhados" compreendendo processos internos e externos. $\mathrm{O}$ primeiro se refere à sobreposição e coesão de seus membros, que é determinante para o pleno uso dos recursos políticos. O segundo se refere à estratégia da coalizão que busca equilíbrio em um sistema político onde há constante barganha e conflito. O desafio de se gerar coalizões duradouras no tempo, ou em políticas setoriais, não tem solução no pluralismo, pois não considera os fatores institucionais ao definir que o poder é diluído, descentralizado, situacional e dependente só da ação dos atores.
} 
interesses organizados a intervir na política local através de mecanismos institucionalizados que podem favorecer certos atores políticos, conforme a sua conveniência. Para Dahl (1989), o governo pode apelar diretamente aos eleitores para apoiar certas políticas buscando ampliar sua legitimidade em projetos ou "áreas em questão". O CAC foi um instrumento de participação política de "fachada democrática" importante para os interesses do governo, embora suas decisões mais importantes não fossem negociadas nesse fórum.

Conforme Dahl (1989), tal instância é uma organização da "base" (grass roots), pois inclui uma rica variedade da vida comunitária, a despeito das decisões significativas continuarem sendo adotadas pelo governo e seus burocratas. Daí que, se o desejo é verificar o alcance democrático para além da superfície da participação, é importante se identificar as decisões sobre temas de interesse e quem frequentemente as inicia. Desse modo, tem-se uma medida mais efetiva para avaliar o peso real dos cidadãos nas decisões governamentais. A conclusão do autor é que o Executivo tem maior iniciativa que a sociedade na definição nos assuntos que considera relevantes de serem referendados de forma participativa.

Ainda assim, estimular e organizar esses canais de diálogo com a sociedade é uma forma de ação muito associada ao perfil do governo, o que sugere que tais fóruns são dependentes do poder público e da linha partidária quando são criados e mantidos. Em outros termos, para a visão de Dahl, colegiados como o CAC politicamente podem servir ao governo para catalisar apoios na sociedade, direcionar ações, formas e locais para aplicar os recursos públicos. Esta situação o autor chama de "ritual democrático", pois o governo busca abrir canais de influência junto a vários atores políticos, sobretudo aqueles que deseja apoiar, cooptar ou mesmo neutralizar a sua oposição. Trazer as forças sociais atuantes para perto do governo pode ser uma estratégia política que também visa reduzir o nível de conflito e de margem de manobra de atores políticos contrários ao governo. Em São Paulo, com a implantação do Orçamento Participativo, bem como a proposta do Conselho de Representantes como instância regional de controle social, o governo pretendia responder a objetivos políticos dessa natureza. Claro que o discurso da democracia participativa e sua materialização em formas de participação popular estavam de perto vinculados ao PT, o partido da Prefeita. Fosse outro o partido, essa forma de mobilização possivelmente seria diferente; bem como a derrota do PT para José Serra em 2004 desmobilizou essa concepção de participação. Para reforçar que há laços entre participação dos cidadãos com a linha política do governo, Dahl destaca que essa não ocorreu espontaneamente, a exemplo do CAC que foi criado pelo prefeito Lee em New Haven. Dahl (1989: 133) avança seu raciocínio dizendo que 
Suas funções no desenvolvimento urbano parecem ter sido grosseiramente equivalentes àquelas executadas pelos rituais democráticos dos partidos políticos realizando indicações para cargos públicos; a participação cidadão deu legitimidade e aceitabilidade para as decisões dos líderes, criou corpos de leais auxiliares que ajudaram a engendrar apoio público para o programa e para evitar disputas.

Ao obter esse consentimento, o governo pode apresentar o programa como se fosse uma iniciativa não partidária, além de difundir junto à sociedade a aparência de que o poder e a responsabilidade sobre a política pública é difusa entre os cidadãos. Agindo dessa forma o governo também aumenta a relevância das instâncias de participação para que suas políticas sejam aceitas e legitimadas pela sociedade. Mas, ainda que Dahl enfatize que os arranjos participativos busquem reduzir a oposição, no caso de São Paulo, a ênfase esteve em buscar ampliar a hegemonia politica do governo e do PT nos movimentos sociais. Para tanto, a aura do Orçamento Participativo como uma arena pública, e não partidária, serviu para esse fim. Também sob o manto do "controle social", com o Conselho de Representantes o governo tinha a intenção de estreitar seus vínculos com os atores políticos nas regiões.

Assim, Dahl destaca que a forma como a participação cidadã é construída traz para a esfera de influência do governo vários atores políticos que se tornam mais predispostos a apoiar suas ações. Este processo ocorre porque tais grupos percebem que podem ser recompensados pelo que o autor chama de "vínculos de lealdade". Em troca, a mobilização de setores sociais serve como contrapartida para fechar esse circuito de "ritual democrático" em favor das políticas de governo, que molda propostas conforme o apoio esperado dos participantes. Tanto que, segundo o autor, uma função politica desse processo é reduzir o conflito entre os grupos sociais e o governo.

Adicionalmente, essas instâncias buscam se colocar como se representassem a opinião pública visando ampliar sua audiência junto ao governo para suas propostas. Este aspecto, que em São Paulo se pautou pelo Orçamento Participativo, deveria ser completado com o Conselho de Representantes. Esta instância sofreu oposição dos vereadores, pois, como os representantes eleitos, não aceitavam a tese de que sua atividade poderia ser fiscalizada pela sociedade local eleita diretamente. Como resultado, o governo recuou de implantar tais fóruns, como será visto no capítulo 2. Segundo Dahl, ainda que a participação cidadã seja importante para sustentar o credo democrático que apela à população, ela não visa expor conflitos que são sempre tratados no estrato político do Executivo e do Legislativo que são, de fato, os espaços em que se realiza a barganha e a construção do consenso político.

Esta crítica serve para analisar como o Orçamento Participativo se inseriu na estratégia política do Executivo na cidade de São Paulo sem peso político face à prioridade que foi 
conferida para organizar a coalizão de apoio na Câmara Municipal. Também é útil para compreender como o governo fez desse processo participativo um recurso político visando hegemonizar segmentos mais organizados da sociedade. A institucionalização de processos participativos fez parte do cálculo político do governo para ter no "apelo" popular meios de interlocução com atores políticos na sociedade. Mas o pluralismo não analisa o sistema político e desconsidera que as instituições e suas normas de funcionamento podem influir na estratégia e ação dos atores políticos. Por exemplo, o governo e os vereadores ocupam espaços institucionais que condicionam a forma como ocorre a decisão sobre políticas públicas. Assim, o lugar que atores políticos ocupam nas instituições pode ser um elemento de barganha, sobretudo se sua posição é considerada estratégica para se garantir apoios políticos continuados. Esta foi a leitura do Executivo municipal em São Paulo sobre os vereadores, ao avaliar que tinham capacidade de barrar projetos, para priorizar a sua política de alianças.

$\mathrm{Na}$ análise da estrutura do poder em Nova Iorque realizada por Mollenkopf (1994), a “coalizão política dominante" é central para se conhecer os atores políticos e as estratégias utilizadas pelo governo para conformar sua base de apoio. Esta concepção é útil para essa pesquisa, pois ajuda a compreender como a implantação das Subprefeituras na cidade de São Paulo teve que equilibrar divergentes grupos políticos no interior do governo, e vereadores de vários partidos, para ampliar a política de alianças. Segundo o autor, o desafio político é converter o sucesso eleitoral em sólida coalizão de governo. Esta, "para permanecer dominante, [...] deve ser capaz de administrar as tensões que inevitavelmente surgem das diferenças de interesse entre sua base eleitoral e seus aliados no governo" (MOLLENKOPF, 1994: 5). Embora "interesses contraditórios" denotem a diversidade de atores, ao construir tal coalizão o Executivo divide seus oponentes e secundariza velhas clivagens políticas, já que refaz as alianças em torno de uma centralidade de poder encabeçada pelo Prefeito.

Politicamente, a coalizão dominante é o ponto focal e uma aliança tática entre diferentes interesses que podem ganhar eleições para os cargos executivos e assegurar a cooperação com outros centros de poder a fim de governar (MOLLENKOPF, 1994). Tais coalizões podem ser estáveis e não apenas conjunturais, operar em questões intersetoriais e não só em arenas temáticas e criar persistentes ganhadores e perdedores. Este processo, com os recursos políticos que o governo possui, cimenta a unidade política entre grupos políticos contraditórios. Por esse motivo, a prefeitura é o ponto fulcral do governo e o objetivo central de toda a coalizão que busca dominar a política local. O sucesso da coalizão depende de sua 
capacidade em diluir conflitos, mediar interesses e, sobretudo, da liderança do Prefeito. ${ }^{4}$ Embora os governos municipais não sejam subprodutos de interesses econômicos, mas devido ao seu "viés sistêmico" em favor do capital ${ }^{5}$, deve-se evitar o "voluntarismo pluralista". Ao mesmo tempo, os governos requerem apoio e legitimação junto aos setores populares implantando, por exemplo, políticas sociais. Mas o sistema político não é tão aberto como vê o pluralismo, embora em "cada função do governo da cidade exista um forte produtor de interesse associado com ele..." (MOLLENKOPF, 1994:71). Por isso, o governo não apenas redistribui recursos entre vários atores políticos, mas acomoda interesses nem sempre coincidentes de grupos políticos aos incorporá-los na coalizão dominante. Daí a importância de se conhecer a forma como se constitui esse arranjo político, a partir das "regras do jogo" da política local que organiza a competição entre interesses e atores.

Metodologicamente, a coalizão dominante busca aproximar a visão sistêmica que vê os governos como dependentes do capital, e o pluralismo que destaca a "acomodação" política de distintos interesses. Da tentativa do autor de aproximar estrutura e ação na análise do poder, interessa à pesquisa verificar as estratégias e escolhas dos atores políticos em relação ao governo municipal. Especialmente as ações do segmento que autor chama de "setor público produtor de interesses" que compreende, dentre outros atores, os executivos eleitos e/ou indicados para exercer funções de governo e os partidos políticos. Estes últimos, em Nova Iorque, segundo Mollenkopf (1994), integravam o governo e dele dependiam para promoverem acomodações políticas. O governo ainda se valeu da divisão de influência partidária nos seus territórios, através de assembleias distritais (assembly districts), para distribuir favores e articular esses diferentes interesses na coalizão política dominante.

Para analisar tal processo, Mollenkopf (1994: 39) elenca algumas perguntas: Como os empreendedores de políticas organizam tais coalizões? O que possibilita que tenham sucesso

\footnotetext{
${ }^{4} \mathrm{O}$ argumento do autor é mais complexo do que a análise pluralista da política como o reino da barganha, pois as mudanças da estrutura socioeconômica influenciam a coalizão política dominante ao eleger os atores políticos chave para apoiar o governo. Contudo, considero que sua abordagem é coerente com o pluralismo, pois, com o prefeito como líder e "ponto focal", a coalizão deve realizar a mediação política entre os atores que a compõem e os constrangimentos sistêmicos. Para Mollenkopf (1994: 35), “dadas certas condições, não é inevitável para uma administração perseguir sucesso eleitoral, investimento privado e gerenciar adequadamente tensões sociais. [...] Nada garante que o governo da cidade estará disposto, ou que seja capaz de cumprir as funções que os estruturalistas têm designado para ele, [...][pois] uma análise estrutural não pode ser adequada até ela especificar "o processo político através do qual [...] imperativos sistemáticos são traduzidos em políticas governamentais".

${ }^{5} \mathrm{~A}$ autonomia política do governo constrangida por interesses econômicos é similar ao conceito de poder sistêmico em STONE (1980). “Os líderes políticos que buscam construir uma coalizão dominante claramente favorecem os investimentos privados que geram incremento no rendimento de impostos [...]. De longe, a mais imediata e intensa conexão entre empreendedores políticos e interesses privados é a necessidade de suporte político. Especificamente, eles necessitam de contribuição de campanha a fim de vencer eleições" (MOLLENKOPF, 1994:92). Para Marques (2003: 44), o autor aponta "mecanismos que produzem desigualdades políticas cumulativas e sistêmicas, que levam à concentração de poder nas mãos de grupos específicos”.
} 
inicial e como sustentam tais acordos ao longo do tempo? Como os interesses em jogo se mantêm vinculados? As instituições políticas e seus processos são importantes para explicar como os partidos políticos constroem coalizões enraizadas em profundas práticas políticas que presidem a articulação de interesses. Assim, os arranjos políticos favorecem tendências conservadoras na formação e atuação da coalizão dominante ao manterem padrões prevalecentes de distribuir empregos, contratos e outros tipos benefícios para uma ampla gama de interesses. Como essa política é centralizada no gabinete do Prefeito, ela revela as escolhas politicas visando se tornar dominante na política municipal. Daí a relevância de analisar os mecanismos de governo que, em Nova Iorque e durante a gestão do prefeito Koch, foram recursos centrais na modelagem da coalizão política dominante.

A construção da coalizão de governo teve um caminho diferente na cidade de São Paulo, pois foi ampliada em relação à coalizão eleitoral PT/PCdoB e alterou a distribuição de cargos amplamente favorável ao PT, partido da Prefeita. Com a criação das Subprefeituras, o Executivo ampliou sua política de alianças ao franquear aos vereadores de outros partidos a indicação de cargos nas regiões, embora o PT fosse o partido hegemônico na maioria dos locais. Mas a forma como as Subprefeituras foram utilizadas para esse fim gerou dois tipos de divergências na coalizão dominante: a) nas regiões, sobretudo onde o PT teve que ceder sua hegemonia à participação de outros partidos e vereadores; b) nas Secretarias municipais, seja por reduzirem sua influência local diante dos parlamentares, seja pelo temor de perderem poder para as Subprefeituras. Esta situação conflitiva no interior da coalizão dominante teve efeitos no caráter errático da descentralização promovida pelo governo municipal.

Além disso, Mollenkopf (1994) chama a atenção para a "nova patronagem governamental" que se cria quando entidades sociais recebem dinheiro público para prestarem serviços comunitários, embora esses atores sejam partícipes coadjuvantes na coalizão política dominante. Como tais organizações passam a depender de verbas públicas, o governo fez desse repasse um recurso político para conquistar apoio junto aos movimentos sociais. Ainda que o Orçamento Participativo em São Paulo não estabelecesse esses vínculos contratuais entre o poder público e as entidades populares, direcionou recursos financeiros para regiões e públicos visando ampliar a hegemonia petista e do governo sobre os movimentos populares.

A prioridade assumida pela lógica da vereança em São Paulo na implantação das Subprefeituras repercutiu na redução da influência das instâncias de participação cidadã no governo e junto aos movimentos sociais. Da mesma forma, o temor das Secretarias municipais em perder poder criou distintas dinâmicas setoriais para a descentralização administrativa. Mas, além da ação dos atores políticos é importante compreender o contexto 
institucional em que se inserem. $\mathrm{O}$ aporte do institucionalismo histórico, conforme (IMMERGUT, 1998; HALL \& TAYLOR, 2003), que será discutido na seção seguinte, é útil para se analisar a implantação das Subprefeituras. Para esses autores, as instituições políticas e as ações de governo incidem sobre a organização de interesses e produzem o contexto onde os atores políticos atuam. Ao mesmo tempo, as instituições são procedimentos, formais ou informais, inerentes a uma comunidade de atores políticos.

\subsection{INSTITUIÇÕES POLÍTICAS, IMPLANTAÇÃO DE POLÍTICAS E SUA INFLUÊNCIA SOBRE A AÇÃO DOS ATORES POLÍTICOS}

Segundo Skocpol (2002), a melhor forma de se analisar as ações do Estado é identificar políticas específicas para conhecer os atores, seus interesses, preferências e estímulos, além dos grupos sociais beneficiados ou desfavorecidos. Tais intervenções do poder público impactam no conteúdo e funcionamento das políticas, e produzem efeitos que geram reações dos atores que são atingidos. Daí a importância de se analisar as estratégias e recursos políticos utilizados pelo Estado e pelos atores no interior de cada política. Este caminho metodológico permite conhecer as irregularidades ao redor das políticas para mostrar áreas em que o poder de Estado é maior ou menor, e as diferenças que existem de comportamento entre diferentes setores no seu interior. Desse modo, é nas arenas de políticas que se explicitam os instrumentos que o Estado dispõe para implantar seus objetivos.

Esta abordagem é similar à de Lowi (1964) e seu conceito de "arenas de poder" como estruturas institucionais de políticas, cujas normas de funcionamento podem ser mais relevantes na decisão sobre políticas do que apenas considerar a ação dos atores. Portanto, deve-se considerar o processo histórico, os alinhamentos institucionais e as expectativas dos atores. Este último aspecto é determinado pelos outputs do governo, que influenciam as coalizões de atores e interesses, conforme o tipo de política em jogo, e produzem impactos nos resultados na vida política com seus acordos, alianças e barganhas. Como poder é a capacidade de os atores participarem na produção das políticas de governo, é importante analisar as arenas de poder que organizam institucionalmente essas relações políticas. Assim, é possível identificar as políticas relevantes em uma arena, e o histórico de decisões anteriores do governo do mesmo tipo, onde houve disputa de interesses a organizar o processo político e as relações entre os atores. Para Lowi (1964), há três tipos de arenas onde se produzem políticas públicas: a distributiva, a regulatória e a redistributiva ${ }^{6}$. Dessas arenas, com seus

\footnotetext{
${ }^{6}$ Para Lowi (1964), as políticas redistributivas expressam interesses generalizáveis e mais facilmente negociados entre sindicatos e burocracia pública. Esta arena de políticas é estável e tem interesses compartilhados entre duas
} 
procedimentos institucionais que induzem o comportamento e o relacionamento entre os atores políticos, para essa pesquisa, empiricamente interessa apenas a primeira.

As políticas distributivas são específicas, individuais, desagregadas, desprovidas de normas gerais e têm no parlamento seu lócus decisional. Como são decisões individualizadas, apenas por acumulação podem ser chamadas de políticas. Em regra, o perdedor e o destinatário dos benefícios não entram em confronto direto e não há exclusões frente às sucessivas acomodações de interesses, pois todos recebem algo. "Patronagem" é o mais amplo sentido da palavra que pode ser tomada como sinônimo de "distributivo", visto que se multiplicam os interesses, o maior acesso dos atores políticos às ações de governo se torna inevitável e a redução do conflito cria uma "estrutura de poder". As coalizões que advém desse processo "devem ser construídas para passar a legislação e "fazer políticas"” (LOWI, 1964: 693). Com a distribuição de benefícios individuais, as coalizões propiciam um relacionamento político de "mútua não interferência" onde alguém busca vantagens para si, sem se opor aos benefícios alheios. Dessa forma, se estende a patronagem e a redução de conflitos entre os atores gera acordos políticos mais estáveis em seu funcionamento.

Esta "estrutura de poder" é formada por atores políticos que não têm compromissos comuns, a não ser facilitar próprio acesso aos benefícios públicos. O governo atua como o "negociador" das concessões junto ao parlamento, que é o local privilegiado dessa política. Sobretudo nas cidades, segundo Lowi (1964: 713), “esta é a arena onde a máquina da dominação continua, se tal máquina estiver no controle em primeiro lugar”. Promove-se a política de cooptação antes que o compromisso, de modo que essa arena constitui um parlamento virtualmente como se esse fosse o próprio governo. Com essa política de atender a um grande leque de atores, o governo visa desarticular a oposição e estabilizar as coalizões. Na cidade de São Paulo, a arena distributiva se materializou na ação do Executivo, visando ampliar a sua coalizão de apoio parlamentar, e as Subprefeituras foram o meio para distribuir benefícios a grupos internos do PT e a vereadores desse e de outros partidos. Esta arena de poder manteve os mesmos procedimentos políticos praticados nos governos Maluf e Pitta.

$\mathrm{O}$ argumento de Lowi também é útil para o objeto dessa pesquisa ao considerar que a política (policy) que está em jogo influi no tipo de relacionamento político dela derivado. $\mathrm{O}$

elites - os "fornecedores de dinheiro" (o setor público) e os "demandadores de serviços" (os sindicatos). Há um princípio associativo que institucionaliza meios de tratar dos conflitos e criar políticas centralizadas afastadas do parlamento que é o local da barganha individualizada. As políticas regulatórias também são individualizadas em seus objetivos, mas identificadas com demandas de grupos e geram benefícios para uns e custos para outros. Nessa arena, o parlamento tem uma função similar àquela atribuída pelos pluralistas na negociação de interesses e, por esse motivo, tais políticas geram coalizões mais instáveis. 
processo político gerado na arena distributiva em torno das Subprefeituras repercutiu na forma como o poder Executivo se organizou no município, diante da divisão das regiões entre grupos políticos, dos vereadores petistas e de outros partidos em torno da politica de alianças.

A abordagem de Lowi das "arenas de poder" e do papel do governo é similar ao que Skocpol (2002: 21) chama de "visão tocquevilliana" do Estado: "sua configuração organizacional, juntamente com outros padrões globais de atividade, afeta a cultura política, encoraja alguns tipos de formação de grupo e ações coletivas (mas não outras), e torna possível a ascensão de certas questões políticas (mas não outras)”. O investigador pode olhar, de forma mais ampla, os meios em que a estrutura e as atividades do Estado influenciam a cultura política, a formação de grupos, a ação política dos grupos na sociedade e as questões da agenda política. Por outro lado, os atores políticos podem definir suas estratégias mediante a maneira como o Estado atua nas arenas de políticas.

Segundo a autora, ainda que a dialética entre Estado e Sociedade incida sobre o conteúdo das políticas, o primeiro é mais importante para moldar a cultura política, as formas de ação coletiva e dos atores políticos. A ação do Estado e sua configuração institucional, portanto, afetam a atuação e os interesses de grupos como os partidos políticos, por exemplo, ao mobilizar suporte às suas iniciativas. A patronagem governamental é um modo de ação política que pode permitir, através de alocações distributivas, novos arranjos administrativos no interior do Estado e pode moldar o comportamento dos partidos políticos. Conforme Skocpol (2002: 25), “estruturas de administração pública e organizações de partidos políticos, consideradas em conjunto, percorrem um longo caminho para "selecionar" os tipos de questões políticas que entrarão (ou serão mantidas fora) da "agenda política" da sociedade." Por exemplo, as agendas políticas podem se direcionar para questões "específicas" de natureza distributiva, quando há uma coincidência entre as necessidades políticas do governo e dos partidos. Assim, uma vez mobilizados os interesses de um grupo político em uma dada direção, esses tendem a manter suas demandas com as mesmas linhas de ação. A atuação do governo da cidade de São Paulo em uma arena de políticas, como foi a criação das Subprefeituras, se pautou dessa forma e configurou a agenda da descentralização junto aos atores políticos envolvidos. Sobretudo, o método de intervenção do governo manteve a prática política de partilhar o poder nos territórios da cidade com vereadores para construir sua coalizão de apoio. Internamente ao governo, a forma como as Subprefeituras foram implantadas influenciou distintos comportamentos, resistência e oposição das políticas setoriais, que contribuiu para o caráter irregular da descentralização de verbas e atribuições às regiões. 
Aqui também o conteúdo das políticas (policies) influencia os relacionamentos políticos, visto que as escolhas em torno das primeiras incidem na ação dos atores políticos, como é o caso dos partidos e seus vereadores. Porém, a "visão tocquevilliana" do Estado em Skocpol apresenta uma moldura geral de relação com a Sociedade em que a agenda do que é considerado politicamente relevante é proposta pelo primeiro. E, dados os recursos políticos e institucionais que possui, o Estado condiciona de forma significativa não apenas o caminho das policies, mas o contexto e o formato dos vínculos políticos com os grupos sociais ao seu redor. Em síntese, as arenas de políticas, a agenda dos temas importantes e os parâmetros da luta e da barganha política têm na ação do Estado um indutor estratégico. Esta foi a situação que ocorreu com a promoção da descentralização e da implantação das Subprefeituras na cidade de São Paulo.

Ao analisar os desafios dos governos locais na Europa, Le Galès (2010) enfatiza que um dos desafios consiste na sua capacidade regulatória como um mecanismo de governança direcionado a ordenar a relação com vários atores sociais, econômicos e políticos. Esta capacidade se define por três dimensões: coordenação de atividades e relacionamento entre atores; alocação de recursos que tal situação demanda e o tratamento de conflitos para impedilos ou resolvê-los. Há três tipos ideais a orientar esse mecanismo de governança: regulação política (o Estado estrutura os conflitos, distribui recursos e coordena as atividades e grupos), a regulação cooperativa/recíproca (também chamada de troca política e baseada em normas e valores) e a regulação de mercado. Para essa pesquisa, os dois primeiros modelos são úteis para verificar como as Subprefeituras alimentaram a regulação política, sobretudo apoiada em procedimentos que governo utilizou visando obter a "cooperação" dos vereadores.

Os atores políticos, portanto, podem realizar seu cálculo político com base nos procedimentos de cooperação institucionalizados que presidem as suas mútuas relações. Este padrão de ação regulatória do governo local permite responder não só a questão quem governa?, à la Dahl, mas também o que se governa? e como se governa? E nesse sentido as funções do governo municipal também se estendem às pressões de reestruturação do Estado para fortalecer suas capacidades organizacionais para "dirigir" a sociedade. Contudo, esse esforço de reconstrução institucional através da implantação de novos desenhos administrativos, ainda que busquem definir uma nova racionalidade na gestão urbana, se depara com outros problemas de ordem política. Introduzir mecanismos organizacionais pode gerar confronto com atores políticos apegados aos seus interesses, segundo os modelos de regulação política e de cooperação em vigor. Situações como essa podem mostrar que o governo não dispõe de capacidades regulatórias para coordenar os distintos interesses dos 
atores políticos, o que pode prejudicar a governabilidade sobre alguns setores. Sobretudo, esse desafio se apresenta quando os governos locais buscam materializar suas intenções regulatórias em políticas concretas. Por exemplo, reformas descentralizadoras que pudessem minar as burocracias existentes e reforçar a democratização dos regimes políticos. Mas, como a experiência das Subprefeituras em São Paulo mostrou, pode gerar comportamentos de resistência e oposição de grupos políticos à frente de órgãos que seriam afetados pela descentralização. $\mathrm{O}$ efeito institucional e político desse processo evidenciou que o Executivo não "governava" todos os grupos internos em direção a um modelo único de gestão regional, o que "minou" a racionalidade da descentralização e acentuou o seu caráter errático.

A abordagem de Le Galès sugere duas questões importantes para essa pesquisa. A primeira se refere às capacidades de direção política do governo local. $\mathrm{Na}$ implantação das Subprefeituras, na cidade de São Paulo, o governo buscou responder ao desafio da governabilidade das políticas urbanas como um fim ou objetivo político. Mas, como será visto no capítulo dois, a resposta às questões como se governa e o que se governa não foi eficaz para opor-se a interesses setoriais que não foram governados na descentralização. A segunda questão se refere à cultura das relações de poder e de troca entre os atores políticos que, na cidade de São Paulo, se materializou na maneira como o governo estruturou sua coalizão de apoio. O Executivo ampliou a política de alianças visando aumentar a governabilidade da política como um meio de implantar seus projetos. Por fim, Le Galès chama a atenção para o fato de as instituições serem formais e terem legitimidade política, como é o caso de um governo local. Contudo, há também as instituições legitimadas pela prática política histórica que mediam a relação entre os atores políticos. Ambas podem conviver no sistema político e conformar a sua dinâmica interna, como será discutido a seguir.

\subsubsection{O processo político e os limites das mudanças institucionais}

Ao falar de "inovação limitada de políticas" (bounded innovation), Weir (1992) se refere aos arranjos institucionais que criam oportunidades de mudança, mas também colocam limites em tais processos. Com o passar do tempo, algumas ideias se tornam menos prováveis de influenciar as políticas das instituições, e podem reduzir os incentivos, acabando por determinar as escolhas realizadas pelos atores políticos. Assim, o desenho institucional do Estado pode estreitar o curso da inovação política, os atores políticos podem agir conforme seus interesses de curto prazo, e em detrimento de modificações organizacionais, visando manter o status quo. As arenas institucionais podem afetar a capacidade dos grupos em influir nas políticas e a forma como seus interesses são definidos pode direcioná-los para formar 
coalizões políticas, tal como (LOWI, 1964). Nesse sentido, é importante compreender como os grupos constroem seus interesses nas políticas e como atuam nos conflitos que surgem no interior das instituições. Para Weir (1992), as políticas e as instituições políticas configuram as possibilidades de os atores influenciarem o curso das ações e a forma como encorajam ou enfraquecem as alianças entre si. E esse processo tem relação com a inovação em políticas e os limites que tais iniciativas costumam carregar por alterarem os interesses de alguns atores, assim como fortalecem a posição de outros no interior da mesma configuração institucional. Por exemplo, a organização interna do Estado influi no desenho das políticas e, a depender da forma como a mudança e a inovação atingem os interesses dos atores envolvidos, pode afetar seu desenvolvimento posterior. Na cidade de São Paulo, tal situação pode ser ilustrada com a já citada oposição das Secretarias municipais à descentralização de atribuições e recursos.

Uma abordagem histórica permite observar as conexões entre essas políticas ao longo do tempo e ajuda a compreender como surgem oportunidades de inovação, além de avaliar as possibilidades de políticas que se abrem em certos momentos, pois segundo Weir (1992: 192), Inerente nessa abordagem está a noção que inovações individuais são parte de uma
"sequência de políticas" nas quais o desenvolvimento institucional apresenta algumas
interpretações de problemas mais persuasivos e faz algumas políticas mais viáveis que
outras. Subjacente ao conceito de uma sequência de políticas está a noção de
"dependência da trajetória": decisões em um ponto no tempo podem restringir futuras
possibilidades de mandar as políticas para fora de caminhos particulares ao longo do
qual as ideias, interesses, instituições e estratégias se adaptam.

Assim, o contorno passado de políticas, e as decisões a elas vinculadas, são mecanismos explicativos para se analisar como os atores políticos atuam. ${ }^{7}$ Ao mesmo tempo, ações inovadoras se deparam com os interesses dos atores nos domínios de políticas públicas e podem gerar resultados que não tem como serem antecipados. Tais colisões são pontos de inflexão, e também de contingência política, que criam oportunidades para os atores promoverem novas visões de políticas. Mas, para King (1992), as ideias são traduzidas em linguagem apropriada à decisão política e frequentemente resultam em metamorfose das noções originais, cabendo aos partidos e seus eleitos um papel crucial nesta "tradução". Um dos efeitos desse processo é a “inovação limitada” na política e das políticas, pois se convive com características prévias do contexto institucional aceitas pelos atores políticos; nesse caso, sobretudo do governo eleito que as mantêm e as legitima. O sistema político inova, mas há

\footnotetext{
${ }^{7}$ Para Hall (1993), a política é influenciada pela experiência passada. Na cidade de São Paulo, a política de partilhar o poder com os vereadores nas regionais para estimular a política de alianças era a norma usual. No governo Marta Suplicy, considerando a dificuldade da gestão Luiza Erundina (1989-1992) de compor uma maioria parlamentar, essa prática política se intensificou com a participação dos vereadores nas Subprefeituras.
} 
“dificuldades de se estender os limites enraizados nas políticas existentes" (Weir, 1992: 211), tal como na formação de alianças políticas que, para Weir (1992: 194), pois

Um dos mais poderosos fatores determinando como grupos definem seus interesses em políticas, e em quais alianças entram, é a organização das instituições políticas. Os aspectos do sistema político que agregam interesses, em particular o sistema de partidos e a legislatura, são centrais. Por canalizarem o modo como os grupos interagem em políticas e produzem políticas, essas instituições afetam enormemente as possibilidades para diversos grupos reconhecerem interesses comuns, construir alianças políticas e frequentemente determinam se tais alianças são necessárias.

Reformas institucionais podem ser pré-requisitos para institucionalizar novas políticas e demandam coalizões políticas que devem ser analisadas para se verificar porque alguns atores políticos são favorecidos em detrimento de outros. Na cidade de São Paulo, este processo ocorreu quando o Executivo transformou as Subprefeituras em moeda de troca para os vereadores passarem a compor sua coalizão de apoio e essa forma de ação foi apresentada como a busca por um "governo amplo". Para se "traduzir" o projeto original da descentralização se manteve a prática política criada no governo Jânio Quadros (1985-1988) de fazer dos territórios um recurso político para cooptar vereadores de outros partidos que não aqueles que fizeram parte da coligação eleitoral.

Conforme Weir (1992), novas instituições, dada a "dependência da trajetória", criam limites em seu desenvolvimento posterior e colocarem barreiras à inovação que estreitam seu escopo. Ao mesmo tempo, esse processo reposiciona os atores políticos como decorrência da revisão que sofre a política em questão. Assim, o governo pode retrabalhar uma política para torná-la aceitável junto a alguns atores políticos e, ao recuar de suas intenções manifestas, reduzir o apoio em outras arenas de políticas. Foi o que ocorreu em São Paulo quando o Executivo limitou o alcance político e institucional das Subprefeituras, ao considerar como prioridade a governabilidade na Câmara Municipal. Mas, ao mesmo tempo, tal ação só fez aumentar a oposição e ampliar as rivalidades das políticas setoriais em relação à descentralização. O mesmo pode ser dito da oposição gerada nos movimentos sociais, quando o governo recuou na intenção de implantar o Conselho de Representantes para não por colocar em risco sua política de alianças.

A maneira de se tratar uma política pode gerar problemas de interação políticoadministrativa e intensificar as dificuldades de relacionamento entre unidades do governo. Sobretudo, quando há dificuldade de se obter consenso entre uma mudança administrativa, que se apresenta apoiada em novas ideias, e a estratégia política amparada em práticas políticas que a limitam. A forma como o governo arquitetou a política da descentralização 
teve efeitos na sua sequência ao manter a moldura política e institucional que prevalecia na gestão dos territórios da cidade, notadamente o mecanismo de partilha de poder.

Também se pode, segundo Weir (1992), analisar o "sequenciamento da política" e os limites de inovação pela forma como se "empacotam" políticas, já que afetam o modo como os grupos definem seus interesses. A forma como se estrutura uma política joga, portanto, um importante papel para aproximar ou afastar os atores políticos e seus interesses, e pode gerar obstruções posteriores para reorganizá-la em novas bases. Pode também ocorrer problemas na implantação de uma política como decorrência do desacordo de alguns atores quanto à forma como ela foi gerada e minar o suporte que ela demandaria. Daí a importância de se conhecer o processo político que embasa as decisões sobre as ações de governo.

Em enfoque um pouco diferente, para Immergut (1992), as instituições estabelecem o contexto estratégico que media os conflitos e relações políticas, além de influenciarem nos resultados de uma dada política. Os atores políticos formulam suas estratégias e o seu lugar no desenho institucional pode beneficiar ou impedir que suas políticas e interesses se traduzam em poder concreto. As instituições configuram o contexto de incentivos, oportunidades e constrangimentos aos atores políticos. E no interior das instituições mais de um curso de ação é possível, pois elas não determinam os interesses dos atores. Desse modo, mudanças no jogo político podem afetar o funcionamento institucional e gerar distintos padrões de comportamentos dos atores políticos em uma mesma arena de políticas. Esta foi a situação que ocorreu durante a descentralização na cidade de São Paulo diante das diferentes formas de ação das Secretarias municipais em relação ao repasse de atribuições e recursos financeiros às Subprefeituras. Conforme Olsen (1984), entre as instituições políticas que podem distribuir recursos e o poder dos atores políticos há influências mútuas. Por exemplo, o partido vencedor nas eleições pode ampliar os "direitos" de participação a alguns atores políticos, o que altera a distribuição de poder e o contexto institucional. Contudo, este desequilíbrio na partilha de poder pode comprometer o curso de uma política se outros atores forem menos considerados. Daí que, para Olsen (1984: 745), “políticas, uma vez adotadas, são inseridas em instituições. Elas são associadas com regras, expectativas e compromissos. Afetando as atenções e as aspirações, elas afetam os futuros comportamentos dos participantes políticos”.

Também para Thelen \& Steinmo (1992), as lutas políticas são mediadas pelo contexto institucional no qual ocorrem. Por tal razão, as instituições produzem a moldura que distribui poder entre os atores políticos e condicionam suas preferências, incentivos e oportunidades, ademais de privilegiar uns em detrimento de outros. Pode ocorrer que certas políticas, inseridas em determinados contextos institucionais, incidam sobre as relações historicamente 
constituídas entre ramos do governo. Em uma mesma arena de políticas, seu desenho institucional pode, portanto, favorecer alguns atores e prejudicar os interesses de outros, e com isso, se tornar um elemento importante para (re) estruturar as relações de poder. Este é o "caráter relacional" das instituições, pois alimentam, ao mesmo tempo, o processo da política e da produção de políticas. Por isso, a análise institucional deve desnudar os interesses e relações de poder que incidem na trajetória das políticas e nas lutas políticas no seu interior. Cabe à ciência política, segundo os autores, investigar os momentos de mudança institucional para identificar como ocorreram nas conjunturas que foram seus pontos de partida. Tal procedimento possibilita conhecer como os arranjos institucionais estruturam e alteram as arenas de políticas que reconfiguram os interesses dos atores e animam sua ação política. Mas a despeito dos constrangimentos institucionais, a análise empírica deve identificar os atores políticos no contexto em que buscam posicionar a defesa de seus interesses e a forma como surgem situações que afetam os resultados de uma política. Por exemplo, manobras dos atores políticos podem influenciar os parâmetros institucionais em que interagem para defender seus interesses. Por outro lado, os atores podem rever suas estratégias, caso seus interesses deixem de ser considerados.

Estes são, segundo Thelen \& Steinmo (1992), fatores de "dinamismo institucional" que podem afetar o jogo político e partilha de poder, geralmente quando velhas instituições são postas a serviço de novos fins. A forma como as Subprefeituras foram concebidas pelo governo municipal gerou tal "situação política", sobretudo as manobras das Secretarias para postergar a descentralização de políticas às regiões. Já na arena parlamentar, o governo recuou no debate sobre a criação do Conselho de Representantes tendo em vista a contrariedade de vereadores da base aliada. Em ambos os casos, o peso das velhas instituições foi uma variável contextual importante a respaldar a ação dos atores políticos. Ainda assim, para Olsen (1984: 742), "o processo de políticas pode ser mais central que seus resultados", pois mesmo que as instituições "estruturem as batalhas" e influam em seus resultados, prevalece a contingência da política. Nos dois exemplos acima, as iniciativas dos atores políticos influenciaram no recuo do governo em relação ao desenho original das Subprefeituras, em especial o escopo da descentralização e dos instrumentos de controle social. Por isso, conforme Thelen \& Steinmo (1992: 9), “onde grupos têm múltiplos, frequentemente conflitantes interesses, é necessário examinar o processo político em que particulares coalizões são formadas".

A aprovação das Subprefeituras serviu de estímulo à ampliação da coalizão política dominante ao partilhar o poder nos territórios com os vereadores e, segundo Borja (1984), essa divisão de espaços foi reflexo da política de alianças no parlamento. A preponderância 
dessa lógica criou distintas situações políticas e administrativas nas regiões da cidade, a depender da forma como cada Subprefeitura foi dividida entre os parlamentares e, sobretudo, a quem coube indicar o Subprefeito e os demais cargos diretivos. Para Thelen \& Steinmo (1992: 16), essa é “uma situação em que velhas instituições são postas a serviço de diferentes fins, com novos atores que entram no jogo e perseguem seus (novos) objetivos através das instituições existentes". O processo político motivado pelas Subprefeituras manteve uma velha prática (partilhar os territórios entre vereadores), com fins idênticos e velhos objetivos do governo (consolidar sua base de apoio na Câmara Municipal). Sob esse ponto de vista, a implantação das Subprefeituras materializou o caráter relacional entre instituições políticas, dependentes de sua trajetória histórica, e os atores políticos com suas estratégias e interesses.

Decerto que as manobras estratégicas dos atores políticos decorrentes da política de governo provocaram conflitos de interesse que influíram no contexto institucional das Subprefeituras. No interior da política da descentralização, os atores políticos (vereadores e Secretarias municipais) se comportaram visando defender seus interesses a partir da lógica política definida pelo Poder Executivo. Cada território se tornou também uma arena política e de políticas públicas, que dispôs de forma distinta os interesses do governo, do Subprefeito e suas equipes, das Secretarias municipais e dos vereadores. A política da descentralização se tornou uma arena de futuras lutas políticas e institucionais que produziu efeitos peculiares em cada dinâmica setorial e nos territórios, notadamente na organização e funcionamento das Subprefeituras. No próximo capítulo será discutida como se deu essa implantação das Subprefeituras como política de governo. 


\section{CONSTRUÇÃO E DESCONSTRUÇÃO NA IMPLANTAÇÃO DAS SUBPREFEITURAS NA CIDADE DE SÃO PAULO}

Este capítulo discute a implantação das Subprefeituras na cidade de São Paulo entre 2001/2004. A análise busca evidenciar como a descentralização administrativa foi errática, pois houve resistência das Secretarias municipais em repassar atribuições às regiões, apesar desses órgãos manterem-se influentes na configuração organizacional das Subprefeituras. O receio da perda de poder desses órgãos centrais fez com que a descentralização das políticas

públicas fosse irregular e impactasse negativamente na gestão intersetorial nos territórios. Prevaleceram iniciativas segmentadas de atuação das Secretarias nas regiões. De outro lado, a análise busca demonstrar que o governo recuou da intenção expressa no programa de governo de implantar mecanismos de participação cidadã nas Subprefeituras, ainda que o Orçamento Participativo tenha vigorado. Sobretudo, o Conselho de Representantes, a ser formado pela eleição direta de cidadãos nas regiões, foi abandonado em favor da prioridade que assumiu a formação da coalizão de apoio na Câmara Municipal. Esta discussão será retomada na análise das Subprefeituras de Capela do Socorro e Freguesia do Ó nos outros capítulos.

\subsection{A CONCEPÇÃO DAS SUBPREFEITURAS NO GOVERNO MARTA SUPLICY}

A implantação das Subprefeituras, a partir de 2002, foi a principal mudança na organização do poder público municipal em São Paulo desde a criação das administrações regionais (doravante chamadas ARs) em 1965. O modelo proposto se baseou no projeto da gestão petista de Luiza Erundina (1989-1992), cuja concepção se encontra em: documentos governamentais (PMSP 1991a, 1991b), livros editados pela Prefeitura (PMSP 1992a, 1992b) elaborações teóricas de atores políticos governamentais (SADER, 1992; JACOBI, 1990; 1991) e artigos acadêmicos (KEINERT, 1993; MARTINS, 1997). Os governos Paulo Maluf (1992-1996) e Celso Pitta (1997-2000) não tinham interesse na sua implantação e o tema só voltou à agenda da política municipal na eleição municipal em 2000.

A crise política e administrativa das ARs no governo Pitta ampliou o consenso entre vários atores políticos que as Subprefeituras seriam a solução para a gestão regional. Em maio de 1998, em debate do jornal Folha de São Paulo, essa foi a opinião da ex-prefeita Luiza Erundina (PSB), do deputado federal Franco Montoro (PSDB) e de Nelo Rodolfo (PPB), presidente da Câmara Municipal. Em abril de 1999, em novo debate nesse jornal, Francisco Whitaker, ex-vereador do PT, defendia as Subprefeituras para combater a corrupção e evitar 
que, tal como as ARs, servissem à barganha com vereadores. De forma similar, para Miguel Colasuonno (ex-prefeito de São Paulo e vereador pelo PPB) e Samir Achôa (vereador do PMDB), as Subprefeituras descentralizariam o Poder Executivo e ampliariam a participação da sociedade. Para o deputado federal Emerson Capaz (PSDB), as Subprefeituras acabariam com a influência dos vereadores e do administrador regional por ele indicado e, juntamente com os Conselhos de Representantes eleitos pelos cidadãos, fiscalizariam os Subprefeitos.

Portanto, na campanha eleitoral no ano 2000, havia um cenário favorável à implantação das Subprefeituras. Tanto que os três principais candidatos de oposição, Luiza Erundina (PSB), Geraldo Alckmin (PSDB) e Marta Suplicy (PT) propunham as Subprefeituras em lugar das ARs. É nesse contexto que o programa de governo da Coligação Muda São Paulo (PT-PCdoB) propõe as Subprefeituras para democratizar o poder político, reconstruir capacidades estatais e ampliar a governabilidade na gestão da cidade. Pela proposta petista, as Subprefeituras implantariam "centros regionais com poder de decisão", de modo que a gestão local se daria em novas bases democráticas e com maior capacidade institucional (SPOSATI, 2001; GARIBE, 2004; 2006, CAPUCCI, 2004).

Propunha-se a gestão das políticas públicas apoiada nos Conselhos de Representantes para exercer o controle sobre as Subprefeituras e a Câmara de Vereadores. Segundo tal visão, as Subprefeituras implantariam esta política por estarem mais próximas do cidadão, e o PT e a bancada governista se apoiariam nos Conselhos para enfrentar a corrupção e o autoritarismo do parlamento. Pela proposta, os fóruns de participação e controle social seriam a base da governabilidade, e o diálogo direto com a população reduziria a influência clientelista dos vereadores que existia na captura das ARs (SPOSATI, 2002; SANTOS e BARRETA, 2004). Vê-se que as características mais importantes desse modelo associavam a descentralização aos fóruns de democracia participativa. Porém, a democracia participativa não foi o modelo para a gestão dos territórios. A estratégia do governo priorizou a composição com os vereadores, e buscou trazê-los para ampliar a coalizão dominante, ao invés de fortalecer a participação social que poderia competir politicamente com essas lideranças políticas eleitas.

Pelo modelo, as políticas públicas locais seriam executadas de forma integrada, o que reordenaria a gestão municipal a partir das demandas locais, ao invés de ações centralizadas e setoriais (MARTINS, 2006; DONATO, 2006; FERNANDEZ e MENDES, 2003). Com a intersetorialidade de políticas, as Subprefeituras atenderiam melhor as demandas oriundas da participação popular e qualificariam a oferta de serviços públicos. A convivência organizacional no interior das Subprefeituras geraria uma maior proximidade entre todas as Secretarias que passariam a atuar de forma integrada. A base comum da ação desses órgãos 
partiria das demandas de cada localidade e promoveria a transversalidade entre as políticas setoriais. Ademais, com tal integração das políticas públicas, se ampliaria a racionalidade administrativa (GARIBE, 2004; 2006, DONATO, 2006 e CAPUCCI, 2004). ${ }^{8}$ A descentralização, associada à democracia participativa, deveria transformar o poder público em favor da sociedade. Contudo, não houve uma política democrática "empurrando" a ação do governo, e tampouco a ação intersetorial foi o eixo organizativo das Subprefeituras. Nas seções seguintes será visto como as opções políticas adotadas pelo governo influenciaram a configuração administrativa e políticas das Subprefeituras nos territórios.

\subsection{SUBPREFEITURAS: A DESCENTRALIZAÇÃO ADMINISTRATIVA ERRÁTICA}

O debate no interior do governo teve três momentos chave, todos marcados por divergências sobre o alcance e a forma de implantar as Subprefeituras:

1. No ano de 2001: o debate interno sobre o modelo da descentralização, configurado no primeiro projeto de lei, e as iniciativas de certas regiões sobre a gestão local.

2. No ano de 2002: a implantação dos "Governos Locais" nas regiões, a aprovação da lei das Subprefeituras e o debate sobre a reforma administrativa do nível central.

3. Nos anos de 2003 e 2004: a implantação administrativa das Subprefeituras e as dificuldades para a descentralização das políticas setoriais.

A seguir será discutido como a descentralização foi sendo descontruída pela ação dos atores políticos governamentais e resultou na sua implantação errática nos territórios.

\footnotetext{
${ }^{8}$ O modelo proposto para a descentralização é próximo de Castells (1989) em Cidade, Democracia e Socialismo. Para o autor, os municípios são o lócus privilegiado para aprofundar a democracia política, facilitada pela emergência dos movimentos sociais. Esta política democrática amplia a consciência política da população e responde melhor à crise urbana para que a cidade seja construída pelo povo e para o povo. Daí a relevância dos governos locais "estenderem formas de democracia", além do direito ao voto, para complementar a democracia representativa. Assim, a sociedade pode se articular no interior do Estado para mudar a direção das políticas, mas preservar sua autonomia para exercer o controle popular. Este empoderamento dos bairros é central para transformar o Estado local, mas não pode ficar restrito em um "paroquialismo populista". Por essa razão, as forças políticas democráticas devem combinar mobilização social, direção política e gestão estatal na estratégia do partido que governa. Esta abordagem é similar à visão petista do Orçamento Participativo para complementar a democracia representativa, e que tem nos movimentos sociais de bairro os seus protagonistas. Esta formulação de Castells é oriunda de Bobbio (2004: 155), para quem "o processo de alargamento da democracia na sociedade contemporânea não ocorre apenas através da integração da democracia representativa com a democracia direta, mas também e, sobretudo através da extensão da democratização - entendida como instituição e exercício de procedimentos que permitem a participação dos interessados nas deliberações de um corpo coletivo - a corpos diferentes daqueles propriamente políticos." Jordi Borja (1984), com o artigo Descentralización: una cuestión de método, também influenciou a concepção desse projeto petista. Para o autor, a base da participação cidadã é o poder local amparado na descentralização política e administrativa, pois seria menor a força dos aparatos não democráticos que dificultam a inclusão na política das massas. A estrutura política mais próxima à população, além de ser mais representativa, ampliaria a democracia e o estímulo à participação cívica. Daí a importância de se identificar os atores políticos favoráveis à descentralização e democracia local e os partidos políticos que desejam manter o caciquismo local. Bem como conhecer a oposição daqueles que, no interior da máquina pública, se sentem atingidos pela reestruturação territorial, a redistribuição de competências e de poder.
} 


\subsubsection{O ano de 2001 e os impasses iniciais em direção às Subprefeituras}

Um dos eixos estratégicos do programa de governo, a descentralização se inseriu na agenda da gestão Marta Suplicy desde o início. O decreto 40227 (01/01/2001), primeiro dia do governo, alterou o nome da Secretaria das Administrações Regionais para Secretaria de Implementação das Subprefeituras (doravante chamada SIS). Contudo, já no primeiro ano de governo surgiram dificuldades para se produzir um acordo sobre o modelo de Subprefeituras a ser implantado. Segundo Ubiratan dos Santos, Chefe de Gabinete da Secretaria de Governo (informação pessoal) ${ }^{9}$, as divergências internas polarizaram-se em torno de dois argumentos: o número de Subprefeituras, combinado com a existência ou não de quadros técnicos capazes.

Ubiratan dos Santos defendia, assim como Jilmar Tatto, a época Secretário Municipal de Abastecimento, a organização imediata das Subprefeituras com uma divisão territorial maior que treze Subprefeituras, que era a base desse modelo na gestão Erundina. Por trás dessa intenção, havia uma avaliação política sobre o refluxo dos movimentos sociais e da militância petista nas regiões. Assim, o número de Subprefeituras deveria reproduzir e/ou ser próximo à distribuição regional do PT para se tornarem instâncias que apoiassem os movimentos sociais e o partido a se organizarem localmente. Mas, no debate interno de governo, o argumento utilizado era que, com áreas menores e limitadas a 500 mil habitantes, haveria uma disputa maior do orçamento. Desse modo, o governo estaria mais bem informado das carências regionais para orientar suas políticas públicas. Esta posição, vitoriosa no debate governamental, entendia que assim seria possível construir o poder local e dividir melhor o orçamento entre as regiões (o anexo um mostra o mapa das Subprefeituras). Logo, todas as políticas públicas deveriam ser descentralizadas para o governo qualificar o atendimento às necessidades dos territórios. Conforme essa visão, as Subprefeituras deveriam ser implantadas no início do governo, pois, diante da desestruturação administrativa das ARs na gestão Celso Pitta (1997-2000), as resistências dos órgãos centrais seriam menores à descentralização.

Para a tese derrotada, defendida pelo primeiro Secretário da SIS, Arlindo Chinaglia, atualmente deputado federal pelo PT, a descentralização era um problema, pois inexistiam quadros técnicos para implantar as Subprefeituras. Assim, as Subprefeituras deveriam ser em menor número para não afetar a qualidade técnica da descentralização e a capacidade de coordenação governamental. Tal posição era apoiada, por exemplo, pelas secretarias de educação, cultura e finanças, temerosas de perder controle político para as regiões. Esta linha de argumentos repetia as posições do núcleo de governo da gestão Erundina, principalmente

\footnotetext{
${ }^{9}$ Entrevista ao autor em 12/02/2010.
} 
de Paul Singer, Marilena Chauí e Amir Khair, contrários ao que chamavam de uma radicalização da descentralização ${ }^{10}$. Por trás desses argumentos técnicos e de racionalidade administrativa havia o temor da perda de poder pelas Secretarias setoriais, como será visto adiante. Portanto, a SIS, criada para implantar as Subprefeituras, apoiava uma visão que foi considerada restrita, no debate interno do governo, da descentralização administrativa.

A aprovação da tese favorável à ampliação do número de Subprefeituras parece ter contribuído para um rearranjo político interno no governo que fortaleceu o grupo da família Tatto. O novo secretário da SIS, Jilmar Tatto (PT), saiu da pasta do Abastecimento e assumiu, em janeiro de 2002, a coordenação da descentralização, que era considerada um projeto estratégico pelo Executivo, além de passar a integrar o núcleo político do governo. A posição de implantar trinta e uma Subprefeituras predominou nas discussões de governo, mas não construiu um consenso em torno de um modelo de unidades territoriais descentralizadas com autonomia política e administrativa. As Subprefeituras passariam a responder por uma gama de políticas públicas regionalizadas, o que significava reduzir atribuições das secretarias. Esta proposta gerou um temor de perda de poder das secretarias e fez com que a descentralização não tivesse as mesmas respostas, ritmo e formas de repassar atividades e recursos às Subprefeituras, como se discutirá adiante. Desse modo, o eixo estratégico da descentralização para modernizar a gestão municipal, quando começou a passar do discurso para a ação política, evidenciou as divisões internas ao governo sobre a sua forma e o seu alcance.

Ainda que o debate interno tenha se pautado por duas posições divergentes sobre a descentralização, em setembro de 2001 o governo apresentou à Câmara de Vereadores o projeto de lei 546/01 propondo a criação de trinta e uma Subprefeituras. O artigo 10 desse projeto propunha uma estrutura organizacional para as Subprefeituras formada pelo Chefe de Gabinete, Assessoria Jurídica e Técnica e, conforme as especificidades locais, de órgãos necessários ao desempenho de atividades administrativas, financeiras, serviços e obras, desenvolvimento social e urbano. Até esse momento, não havia um modelo administrativo definido para as Subprefeituras, que veio a ser apresentado apenas na versão final da lei que as criou em julho de 2002. Com efeito, até o final de 2001, o debate interno ao governo não gerou uma proposta clara de como seria administrativamente organizada a descentralização. Tanto que, pelos artigos 16 a 19 do projeto de lei ficava o Executivo autorizado a criar as unidades gerenciais para atender as demandas locais e regulamentá-las através de decretos.

\footnotetext{
10 À época esse debate traduzia uma disputa ente os diretórios zonais do PT, a quem caberia indicar os Administradores Regionais, e os "intelectuais" e "técnicos" do partido, a quem caberia ocupar as Secretarias. Enquanto os primeiros buscavam ampliar a descentralização, os segundos desejavam maior controle politico.
} 
Mas é possível que o governo não quisesse explicitar a magnitude da descentralização para a Câmara Municipal, pois, em 2001, sua base parlamentar era minoritária. Já os vereadores tinham interesse em manter sua influência nos territórios. Assim, é pouco provável que aprovassem uma lei autorizando o Executivo a regulamentar as unidades gerenciais e seus ocupantes pelo temor de não mais indicarem pessoas para cargos locais. Muitos parlamentares recordavam da gestão Erundina, quando as ARs foram distribuídas entre os diretórios zonais do PT (TEIXEIRA, 2004). Como visto anteriormente, tal modelo ainda tinha defensores no governo que, somado ao discurso do controle social, fazia os vereadores de outros partidos recearem sobre sua influência política no comando das ARs. A dificuldade de o governo construir uma maioria parlamentar, associada ao receio de perder a votação e não conseguir implantar as Subprefeituras, como ocorreu na gestão Erundina, adiou a tramitação do projeto. De outro lado, os vereadores sabiam que o governo teria que negociar para obter os votos favoráveis ao projeto. A esse contexto somou-se a disputa por cargos entre vereadores da base governista e o medo de que, com as Subprefeituras, surgissem líderes regionais que diminuíssem o poder dos parlamentares. O projeto de lei foi apresentado em setembro de 2001 e aprovado em julho de 2002, sobretudo pela ausência de acordo na coalizão governista.

Porém, ainda que em 2001 a descentralização não tenha sido implantada, algumas regiões, de forma autônoma, criaram instrumentos de gestão local. Especialmente as ARs com quadros políticos que participaram dos "Governos Locais" na gestão Erundina. Esta foi a situação na Freguesia do Ó, onde a Administradora Regional, Márcia Barral (PT), fora chefe de gabinete da AR, ademais de outros técnicos com a mesma experiência prévia. No capítulo três será discutida a trajetória da descentralização nesse território. $\mathrm{Na}$ Capela do Socorro, o Administrador Regional, Tadeu Pais (PT), fora chefe de gabinete dessa AR no governo Erundina e, em fevereiro de 2001, implantou o NICS (Núcleo Intersecretarial da Capela do Socorro). Este fórum era composto por representantes indicados das secretarias e órgãos municipais. No capítulo quatro será debatida a forma como se deu a implantação da Subprefeitura nessa região.

\subsection{2 $\mathrm{O}$ ano de 2002: o discurso virtuoso da descentralização diante da disputa política}

Este ano teve duas etapas centrais: a) a implantação dos Governos Locais visando preparar a transição às Subprefeituras, e que parece ter sido, conforme o relato de vários entrevistados, o momento mais positivo da descentralização na gestão Marta Suplicy; b) a aprovação da lei 13399/2002 que criou as Subprefeituras e deu início à sua organização. 
Em março desse ano, a administração municipal reativou os "Governos Locais" através do Decreto 41813/2002. Esta iniciativa ocorreu já na gestão de Jilmar Tatto e foi a forma de o governo manter as Subprefeituras na sua agenda política. Os "Governos Locais" eram fóruns vinculados às ARs, constituídos por técnicos das Secretarias para produzir diagnósticos integrados dos territórios e propor ações intersetoriais descentralizadas. O Executivo entendia que assim seriam criadas as bases organizacionais que facilitariam a transição para a criação das Subprefeituras, apesar do poder decisório se manter nas Secretarias. Contudo, a formalização das Subprefeituras não aprofundou essa lógica descentralizadora de políticas. Após julho de 2002, quando o enfoque passou a ser a regionalização, se intensificou a oposição política de várias Secretarias em dividir atribuições com os territórios. Enquanto as ARs continuavam comandadas pela SIS, e se mantinham como instâncias administrativas de segundo escalão, não alteraram a estrutura de poder das Secretarias. Esta realidade mudou quando os "Governos Locais", fóruns desconcentrados, foram substituídos pela descentralização administrativa das Subprefeituras, com quem as Secretarias deveriam dividir atribuições e recursos financeiros.

Além do mais, as entrevistas realizadas com Subprefeitos e coordenadores regionais indicaram que a proposta de fazer dos "Governos Locais" uma transição administrativa para as Subprefeituras teve o resultado oposto. Segundo Juan Fernandez, assessor da Subprefeitura da Capela do Socorro, se criou um paradoxo que afetou a produção de políticas nas regiões. No "Governo Local", os representantes das Secretarias não tinham incumbências administrativas; com as Subprefeituras se tornaram coordenadores sobrecarregados de tarefas organizacionais. A ação desconcentrada dos "Governos Locais", focada em projetos integrados nos territórios, cedeu espaço às atividades administrativas e de caráter setorial nas Coordenadorias regionais (informação pessoal)". Se os "Governos Locais", como argumentam Torrecillas e Sousa (2006), o primeiro Administrador Regional da Mooca e futuro Subprefeito da Sé, ajudaram a melhorar os serviços públicos e as ações intersetoriais integradas em saúde e educação, esse modelo não se manteve posteriormente. O que deveria ser um processo prévio para organizar as Subprefeituras não criou bases organizacionais sustentáveis, nem ampliou a disposição política das Secretarias municipais com a descentralização. Políticas que já possuíam estruturas desconcentradas, como a assistência social, ou com mais recursos, como a educação, receavam que as Subprefeituras, carentes de estrutura administrativa, interferissem na sua autonomia setorial. Mas, a despeito desses

\footnotetext{
${ }^{11}$ Entrevista ao autor em 21/06/2010.
} 
limites, os "Governos Locais" foram bem avaliados pelos entrevistados como fóruns de produção integrada de políticas nas regiões, comparativamente ao período das Subprefeituras.

O segundo momento iniciou em julho com a aprovação da lei 13399 que criou as 31 Subprefeituras. Regulamentou-se a Lei Orgânica Municipal (LOM) que, no artigo 77, determinava que "a administração municipal será exercida, em nível local, através de Subprefeituras". Estas passaram a ter poder formal de decisão, planejamento, investimento e autonomia administrativa na gestão regional. A mesma lei regulamentou outros artigos da LOM: igualou Subprefeitos e Secretários como auxiliares diretos do Prefeito; definiu as Subprefeituras como representantes locais da administração municipal e as transformou em unidades orçamentárias. Em tese, o Subprefeito seria o representante político local do governo, e com mais poder decisório se comparado aos administradores regionais que respondiam apenas por serviços de manutenção urbana (SANTOS \& BARRETTA, 2004).

Antes de seguir na análise da descentralização, é importante apresentar a divisão interna das Subprefeituras em sete coordenadorias, conforme o artigo 12 da lei 13399: a) Ação Social e Desenvolvimento: trabalho, assistência social, abastecimento, esporte, lazer e cultura; b) Planejamento e Desenvolvimento Urbano: planejamento urbano, habitação, transportes, controle e fiscalização do uso do solo e conservação do meio ambiente; c) Manutenção e Infraestrutura Urbana: manutenção das vias públicas, rede de drenagem, limpeza urbana, conservação das áreas verdes e próprios municipais; d) Projetos e Obras Novas: elaboração, execução e gestão de projetos e obras novas; e) Educação: execução e gestão dos serviços da área, recursos humanos e financeiros; f) Saúde: assistência à saúde, vigilância sanitária e epidemiológica, recursos humanos e financeiros; e g) Administração e Finanças: apoio administrativo, orçamentário e gestão de pessoas às demais Coordenadorias. Porém, essa estrutura que deveria responder pela descentralização se deparou com uma relação desencontrada entre as Secretarias municipais e as Subprefeituras, sem gerar uma coordenação articulada de competências (BORJA, 1984). O Anexo dois mostra tais vínculos hierárquicos e funcionais e o organograma das Subprefeituras (lei 13682/2003).

A Coordenadoria de Ação Social e Desenvolvimento reuniu as atividades de cinco Secretarias: Abastecimento, Assistência Social, Esportes e Lazer, Cultura e Trabalho. A Coordenadoria de Administração e Finanças englobou as Secretarias de Gestão Pública e a de Finanças e Desenvolvimento. A Coordenadoria de Planejamento e Desenvolvimento Urbano assumiu atribuições de quatro secretarias (Planejamento, Habitação, Transportes e do Verde e Meio Ambiente). A Coordenadoria de Manutenção e Infraestrutura Urbana as atividades da Secretaria de Infraestrutura Urbana e do Departamento de Limpeza Urbana (LIMPURB), a 
Coordenadoria de Projetos e Obras Novas as funções da Secretaria Municipal de Serviços e Obras (Departamento de Edificações). As áreas de educação e saúde eram coordenações próprias pelo porte e pelas transferências de recursos do governo federal demandar uma gestão orçamentária específica. No gabinete do Subprefeito se localizaram pastas como Comunicação, Negócios Jurídicos, Governo e Segurança Urbana (Defesa Civil). A dimensão dessa transferência de atividades para todos os territórios é um indicador dos desafios políticos que existiram para viabilizar tal processo junto às Secretarias. ${ }^{12}$

No segundo semestre de 2002, o debate no Executivo se centrou em duas questões: negociar com as Secretarias o que e como descentralizar e o organograma das Subprefeituras. Esta discussão evidenciou a dificuldade de se gerar consensos entre a Secretaria Municipal das Subprefeituras, criada para coordenar a descentralização no lugar da SIS, as Secretarias setoriais e as Subprefeituras. A justificativa governamental de que a descentralização seria "processual" parece, portanto, mais um eufemismo para encobrir esses impasses políticos internos. Este embate influenciou a configuração institucional das Subprefeituras, em face dos diferentes caminhos que as Secretarias sugeriram para descentralizar suas políticas. Sobretudo, o debate revelou a ausência de um projeto mais bem definido do governo para avançar, além de objetivos e do conceito geral, na implantação efetiva das Subprefeituras.

O governo operava com um cenário em que, após a aprovação da lei, haveria uma adesão das Secretarias à descentralização. O instrumento utilizado pela Secretaria Municipal das Subprefeituras (doravante chamada SMSP) foi um oficio aos órgãos solicitando que apresentassem o que repassariam às regiões. Tal expediente evidencia a falta de um projeto mais estruturado de descentralização, pois, só após se aprovar a lei, abriu-se a discussão para as Secretarias indicarem o que entendiam passível de ser repassado às Subprefeituras. Mas o resultado obtido com esse método foi o oposto: as Secretarias buscaram justificar como deveria ser a sua organização setorial no território ou apresentaram as razões para manterem centralizadas várias atividades. Esta situação é identificada no caderno "Documentos sobre a descentralização político-administrativa do Município de São Paulo" organizado pela SMSP em outubro de 2002. Neste material estão as respostas das Secretarias ao ofício que requeria suas propostas setoriais para a descentralização. Para evidenciar as divergências das Secretarias, abaixo se apresentam os argumentos de algumas políticas sociais que eram consideradas a grande inovação da gestão local intersetorial e descentralizada.

\footnotetext{
12 Por exemplo, pelo Decreto 42325/2002, as Subprefeituras passaram a ter três unidades orçamentárias: Administração da Subprefeitura, Coordenadoria de Educação e Coordenadoria de Saúde. Na prática semanteve a autonomia de ação e as estruturas administrativas dessas duas áreas, a despeito de o Subprefeito ser o ordenador de despesas, afora as relações de subordinação às Secretarias setoriais em temas de natureza regional.
} 
Na Coordenadoria de Ação Social e Desenvolvimento, a Secretaria da Assistência Social (SMAS) protagonizou o maior enfrentamento com a SMSP sobre a descentralização de uma política setorial. A área reivindicava a organização de uma Supervisão Regional de Assistência Social diretamente vinculada aos Subprefeitos. Em uma correspondência datada de 25/10/2002, a Secretária Municipal, Aldaíza Sposati, se dirige ao Secretário Jilmar Tatto, coordenador da descentralização nos seguintes termos: "desconheço os motivos que levaram V. Exa. ou a equipe dessa pasta a deletar a política de assistência social da gestão regional”. A Secretária entendia que a assistência social, a exemplo da educação e saúde, fazia parte de um sistema nacional único descentralizado e participativo. Desse modo, também requereria uma estrutura organizacional própria para gerir os seus programas nos territórios e deveria ser uma unidade orçamentária, ao invés de integrar a rubrica de administração da Subprefeitura. Alegava-se que esse desmembramento se justificava pelo estágio mais adiantado da descentralização frente a outras áreas que sequer haviam iniciado tal processo. Para a Secretária da pasta (informação pessoal) ${ }^{13}$, havia também o risco de regressão e de involução nas políticas setoriais, caso fossem descentralizadas sem critérios técnicos.

Na transição para as Subprefeituras, a SMAS manteve centralizada a definição da política setorial e a homologação de convênios, que era o meio central para executar suas ações nas regiões. A descentralização se limitou a aspectos administrativos como o suprimento de material básico para as SAS Regionais, provisão de veículos para uso exclusivo da área e a avaliação de imóveis para o conveniamento de entidades. Além disso, o desenho organizacional foi proposto para atender suas demandas setoriais. Havia uma área exclusiva de documentação/informação e a administração de pessoal deveria ser competência das Supervisões locais. O desfecho desse debate foi a manutenção das Supervisões de Assistência Social nas Coordenadorias de Ação Social e Desenvolvimento das Subprefeituras. Contudo, os reflexos do embate na organização dessa política foram distintos em cada território da cidade, como será analisado nos capítulos 3 e 4. Um indicador da discordância da área sobre a descentralização é que apenas em outubro 2004, no final do último ano de governo, o Decreto 45438/2004 transferiu os Centros de Convivência para as Subprefeituras.

A Secretaria do Desenvolvimento, Trabalho e Solidariedade (SDTS) alegava que, dada a concepção intersetorial de seus programas, deveria ser uma assessoria no gabinete do Subprefeito. Discordava da sua subordinação à Coordenadoria de Ação Social e Desenvolvimento com o argumento da perda de agilidade administrativa. Esta divergência

\footnotetext{
${ }^{13}$ Entrevista ao autor em 10/03/2010.
} 
reverberava a disputa, no nível central do governo, sobre a gestão dos programas sociais entre a SDTS e a Secretaria Municipal de Assistência Social.

A Secretaria de Habitação e Desenvolvimento Urbano (SEHAB) propunha descentralizar serviços como regularização fundiária, aprovação de arruamento, desdobro de lote até $1000 \mathrm{~m} 2$ etc. Porém, foi apenas em fevereiro de 2004, com o Decreto 44418, que se normatizou a primeira etapa de transferência de atribuições da pasta para as Subprefeituras, o que é um indicador da oposição do órgão à descentralização. Ademais, o planejamento e a execução da política habitacional de interesse social, que respondiam pela regularização de assentamentos precários, urbanização de favelas etc., se mantiveram centralizadas na SEHAB. Esta posição se baseava na concepção de descentralização adotada pelo órgão que era focada em estreitar vínculos com as Associações Comunitárias. Nos capítulos 3 e 4 ver-se-á como a ação repercutiu na Freguesia do Ó e na Capela do Socorro.

A Coordenadoria de Educação era considerada pela Secretaria Municipal da Educação sua representante nos territórios. Seria uma unidade orçamentária com atribuições de planejar e administrar recursos financeiros, materiais e humanos. Tal proposta contrariava a concepção de implantar uma Coordenação de Administração e Finanças nas Subprefeituras para apoiar todas as políticas descentralizadas. Na visão da Secretaria de Educação, a área teria uma diretoria de recursos humanos e uma diretoria financeira, o que evidenciava a busca de manter autonomia funcional nas suas ações. A mesma independência de atuação setorial se apresentava na implantação da política de comunicação, na manutenção e zeladoria dos prédios utilizados pela Coordenadoria. O argumento era que a "descentralização" da Prefeitura não pode "centralizar" atividades nas Subprefeituras sem atentar para as diversidades setoriais. Buscava-se uma descentralização administrativa restrita ao âmbito da política educacional, sem o temor da divisão de recursos financeiros com outras áreas, a despeito de se propor uma Diretoria para realizar ações intersetoriais nas Subprefeituras.

Diante do exposto, parece que o caminho adotado pelo Executivo de construir um modelo geral da descentralização, sintetizado na lei 13399, e a ser posteriormente detalhado pelas secretarias e órgãos municipais, não logrou êxito. Ao invés de uma adesão à proposta descentralizadora, as áreas buscaram manter atividades centralizadas e/ou propunham setores autônomos na estrutura das Subprefeituras. O governo não teve capacidade política de coordenar e construir um consenso das distintas das Secretarias dentro do arcabouço institucional previsto para as Subprefeituras. Será discutido nos capítulos 3 e 4 o efeito político e administrativo desses impasses na implantação das Subprefeituras, sobretudo pela 
desigualdade de atuação das políticas setoriais nos territórios. Um dos efeitos dessa situação foi que a gestão intersetorial e transversal de ações nos territórios não foram bem sucedidas.

Ainda no ano de 2002, em dezembro, o governo editou a Portaria Intersecretarial n. 6 que definiu a estrutura organizacional das Subprefeituras para recepcionar os serviços, recursos humanos e materiais transferidos dos órgãos da administração municipal. Esta foi uma solução precária, face às divergências existentes, do ponto de vista legal, administrativo e político para garantir continuidade na implantação da descentralização. Isto porque a lei 13399 aprovou a criação dos cargos de trinta e um Subprefeitos e dos sete coordenadores, mas não a estrutura administrativa necessária à gestão dos territórios.

Nesse ano, também ocorreu o debate sobre reforma administrativa do nível central de governo, e que também gerou divergências no interior da gestão. A SMSP, secretaria coordenadora da descentralização, compreendia as Subprefeituras como parte estratégica, mas não isolada, da reorganização do Estado em nível municipal, a exemplo do modelo proposto na gestão Erundina em 1991. A descentralização exigiria rever estruturas e funções das Secretarias para compatibilizá-las com o modelo organizativo das Subprefeituras. O projeto apresentado pelo Secretário Jilmar Tatto no início de 2002 foi concebido na AR de Capela do Socorro pelo administrador regional Tadeu Pais (que era do grupo político do Secretário Tatto) e seus assessores mais próximos ${ }^{14}$. Pela proposta, as Subprefeituras deveriam ser as protagonistas de uma reforma política e democrática do Estado em nível municipal. Este projeto de redesenho da administração central foi apresentado pela SMSP ao núcleo do governo e não foi aceito, excetuado um compromisso genérico na lei 13399. Pela redação do artigo 21, até janeiro de 2004, as estruturas organizacionais centrais, com seus quadros e funções executivas, seriam compatibilizadas para evitar duplicidades. Tal ação foi prorrogada para dezembro de 2004 pela Lei 13682/2003 e não foi implantada até o final do governo.

Esta proposta não foi adiante por duas razões: a) a perda de poder das Secretarias para as Subprefeituras desestabilizaria a divisão interna de espaços no governo, sobretudo entre as correntes internas do PT que eram hegemônicas na esfera central; b) o acordo do governo com vereadores da coalizão de governo, especialmente do PT, de aceitar indicações para Subprefeitos e cargos diretivos locais seria "pressionado" pela redução das estruturas centrais. Este debate ainda suscitou uma divergência no interior do próprio núcleo político do governo, pois Jilmar Tatto, que era secretário da SMSP e coordenador da descentralização, abriu várias

\footnotetext{
${ }^{14}$ Informação confirmada a esse pesquisador por Tadeu Pais (entrevista em 22/04/2010) e seus assessores Juan Aneros Fernandez (entrevista em 21/06/2010) e Cássia Goretti da Silva (entrevista em 25/05/2010).
} 
frentes de disputa com Secretarias resistentes às Subprefeituras. Como já visto, a mais contundente foi com a pasta da assistência social e se refletiu na gestão dessa política na Subprefeitura de Capela do Socorro onde a família Tatto era hegemônica, como será discutida no capítulo 4. Além disso, Tatto assumira um protagonismo grande na condução política da descentralização que, se encaminhado como propunha, ampliaria seu poder junto aos territórios e poderia aumentar seu peso político na sucessão da Prefeita em 2004. Para reduzir essa influência, a saída foi criar um colegiado formado pela SMSP, Secretaria de Gestão Pública (SGP) e Secretaria de Governo Municipal (SGM). Assim, os grupos concorrentes, através do Decreto 42561 de 30/10/2002, puderam "identificar os órgãos incumbidos de coordenar a referida descentralização". A partir de então, todas as questões acerca das Subprefeituras deveriam ser tratadas por essa comissão, a exemplo da Portaria Intersecretarial n. 6 sobre a estrutura organizacional. Alterou-se a direção política da descentralização que buscou equilibrar o poder entre os grupos concorrentes do Secretário da SGM, Rui Falcão, e a crescente influência da família Tatto no Executivo e no diretório municipal do PT, além de o vereador Arselino Tatto ser o indicado do governo para presidir o parlamento em 2003.

A constituição desse colegiado parece ter representado uma inflexão definitiva sobre o modelo administrativo das Subprefeituras na gestão Marta Suplicy. Com a criação dessa comissão, a SMSP perdeu autonomia de ação, associada à derrota do projeto de reforma administrativa no nível central do governo. Um dos efeitos políticos dessa mudança foi a saída de Jilmar Tatto no final de 2002, substituído por Antônio Donato, até então assessor do Gabinete da Prefeita. A partir desse momento, o projeto das Subprefeituras se reduziu à descentralização administrativa de serviços, recursos materiais e humanos que, em grande medida, já atuavam de forma desconcentrada nas regiões.

Em termos administrativos, a opção do governo de manter inalteradas as estruturas do nível central, e ao mesmo tempo implantar as Subprefeituras, gerou um modelo organizacional com dois vetores contraditórios. Havia vinte e três secretarias na administração direta que deveriam se relacionar com sete coordenadorias em cada Subprefeitura. No nível central permaneceram estruturas setoriais que temiam a perda de poder para as regiões, enquanto nas Subprefeituras o desenho organizacional pretendido era a intersetorialidade e transversalidade nas ações. O resultado foi um permanente desencontro gerencial e político do nível central com as regiões decorrente da incompatibilidade dos dois modelos organizacionais e decisórios. O caso mais significativo foi a Coordenadoria de Assistência Social e Desenvolvimento que gerenciava atividades realizadas por cinco órgãos que continuavam a operar de forma setorial e desintegrada no nível central. Em situações como 
essa, ações locais de caráter intersetorial demandavam decisões de cinco secretarias municipais, sem que no nível central existissem instâncias para realizar tal mediação. Como não havia concordância de todas as Secretarias com a descentralização em curso, era pequena a possibilidade de se criarem fóruns temáticos e integrados de políticas na esfera central do governo. Um dos efeitos não previstos dessa oposição foi transformar as Secretarias, e não as Subprefeituras, em atores chave da descentralização, pois passaram a condicionar a forma, o ritmo e o conteúdo desse processo. É nesse sentido que a implantação das Subprefeituras foi errática, limitada em alcance administrativo e desigual na capacidade de gerir políticas públicas nas regiões. Esta foi uma das heranças deixadas para o período iniciado em 2003, cujo foco deveria ser a organização Subprefeituras, como será discutida na próxima seção.

\subsubsection{Os anos 2003 e 2004: os limites e impasses na implantação das Subprefeituras}

Esta etapa se inicia com o desafio de implantar os dois marcos legais das Subprefeituras: a lei 13399 e a estrutura organizacional da Portaria Intersecretarial n. 6. Para tanto, uma das medidas adotadas desde o início de 2003, foi a edição de vários decretos transferindo unidades administrativas das Secretarias municipais às Subprefeituras. Basicamente serviços e equipamentos já desconcentrados nos territórios foram repassados às Subprefeituras: gestão dos equipamentos de esportes (decreto 42770/2003); gestão dos equipamentos de educação (decreto 42773/2003); c) gestão dos equipamentos de saúde (decreto 42771/2003) e; d) gestão dos equipamentos de cultura (decreto 42772/2003). Nessas quatro áreas também se transferiram bens patrimoniais, serviços e pessoal; f) desconcentração do Programa de Silêncio Urbano (PISU) da Secretaria Municipal de Abastecimento para cinco Núcleos Regionais (decreto 43799/2003); g) administração e fiscalização dos mercados municipais oriundos da Secretaria Municipal de Abastecimento (decreto 43796); e h) transferência dos Centros Educacionais Unificados (CEUs) (decreto 43822/2003).

Com essas medidas se formalizaram as competências administrativas dos Subprefeitos sobre serviços já presentes nos territórios. Vê-se pela tabela 2.1 que, cerca de um ano após a edição dos decretos acima mencionados, as Subprefeituras administravam 72,8\% do total de servidores municipais. Deste total, 69,6\% era oriundo da Secretaria de Educação e se tratava basicamente de professores, funcionários e supervisores de escolas. Como essa área era uma unidade orçamentária nas Subprefeituras, a gestão da folha do magistério foi descentralizada e inflou o orçamento dos territórios. Da Secretaria da Saúde foram repassados 10,9\% de servidores que atuavam, sobretudo, nas Unidades de Saúde já desconcentradas. Neste cômputo não estavam os profissionais do Programa de Saúde da Família (PSF) executado por 
entidades conveniadas. A Secretaria Municipal das Subprefeituras apenas formalizou a transferência de 7,6\% do total de servidores, cujo local de trabalho já era o mesmo desde o período das ARs por estarem lotados na antiga Secretaria das Administrações Regionais. A Secretaria Municipal de Esportes, da mesma forma, formalizou a cessão de 1,2\% de servidores que já atuavam em seus equipamentos desconcentrados. O mesmo ocorreu na Secretaria de Cultura que repassou às Subprefeituras a gestão 0,9\% do total de servidores. Estas cinco áreas responderam por $90 \%$ do montante de servidores transferidos aos territórios. Com efeito, na gestão de pessoas não houve descentralização, mas apenas a transferência formal da responsabilidade administrativa das Secretarias para as Subprefeituras, notadamente naquelas atividades já realizadas de maneira desconcentrada nos territórios.

Tabela 2.1 - Servidores transferidos da administração central para as Subprefeituras

\begin{tabular}{lccc}
\hline \multicolumn{1}{c}{ Servidores ativos } & Março de 2003 & Março de 2004 & Variação \% (03-04) \\
\hline Subprefeituras & - & 96.257 & $-97,96$ \\
Educação & 68.369 & 1.396 & $-73,07$ \\
SMSP & 10.115 & 2.832 & $-72,18$ \\
Saúde & 19.150 & 5.328 & $-68,92$ \\
Esportes & 1.644 & 511 & $-35,16$ \\
Abastecimento & 876 & 568 & $-34,78$ \\
Cultura & 2.516 & 1.641 & $-11,47$ \\
Governo & 767 & 679 & $-11,01$ \\
Gestão Pública & 854 & 760 & $-9,01$ \\
Assistência Social & 1.764 & 1.605 & $-7,18$ \\
Autarquias da Saúde & 8.764 & 8.135 & $-6,00$ \\
Planejamento & 200 & 188 & $-6,00$ \\
Comunicação & 200 & 188 & $-5,02$ \\
Transportes & 299 & 284 & $-4,75$ \\
Infraestrutura & 442 & 421 & $-2,07$ \\
Meio Ambiente & 917 & 898 & $-0,16$ \\
Negócios Jurídicos & 1.285 & 1.283 & 0,00 \\
Habitação & 747 & 747 & 3,07 \\
Serviços e Obras & 781 & 805 & 3,84 \\
Finanças & 1.485 & 1.542 & 8,62 \\
Trabalho & 58 & 63 & 16,69 \\
Segurança Urbana & 5.218 & 6.089 & 27,27 \\
Ouvidoria & 22 & 28 & 50 \\
Relações Internacionais & 16 & 24 & \\
\hline TOTAL & 126.889 & 132.272 & \\
\hline Fonte: Secretara & Pá & & \\
\hline
\end{tabular}

Fonte: Secretaria Municipal de Gestão Pública, 2004.

Para o governo, esse processo era preparatório à segunda etapa que demandaria ação intersetorial e transversalidade de políticas nos territórios (SANTOS \& BARRETTA, 2004). Porém, como se atingir tal objetivo com tamanha desigualdade na transferência de servidores e, por extensão, de serviços e atividades? Na prática prevaleceram duas lógicas assentadas no desenho institucional existente: a realização de serviços de manutenção urbana, herança histórica dos Distritos de Obras desde a década de 50, e a oferta de serviços de saúde, 
educação e assistência social, que já ocorriam de forma desconcentrada. Esta foi a tônica da descentralização administrativa limitada e irregular de políticas.

A implantação das Subprefeituras também pode ser avaliada pelo montante de recursos transferidos às regiões. Em 2003, o valor foi de R \$ 550 milhões e para 2004 previase quase $\mathrm{R} \$ 3$ bilhões, 20,9\% do orçamento municipal, conforme a figura 2.1. Mas, no orçamento municipal, as três áreas representavam pouco mais de $20 \%$ : Educação (12,6\%), Manutenção e Infraestrutura (4,84\%) e Saúde (2,68\%), a despeito da ênfase do discurso do governo na descentralização. Segundo a Secretaria Municipal de Finanças e Desenvolvimento Econômico (2004), essas três áreas totalizavam 96,31\% dos valores orçamentários médios das Subprefeituras. No entanto, frise-se que, na Educação e Saúde, as verbas foram notadamente direcionadas ao pagamento de pessoal (professores, funcionários de escolas, médicos, equipes de PSF etc.) e custeio administrativo (escolas e unidades de saúde). Na área de zeladoria urbana existiam valores orçados desde o período das ARs. Já a Coordenadoria de Assistência Social e Desenvolvimento, que reunia seis políticas setoriais para "promover qualidade de vida e desenvolvimento humano", correspondia a apenas $1,82 \%$ do orçamento médio das Subprefeituras e $0,0025 \%$ do orçamento municipal!

Figura 2.1 - Execução orçamentária descentralizada

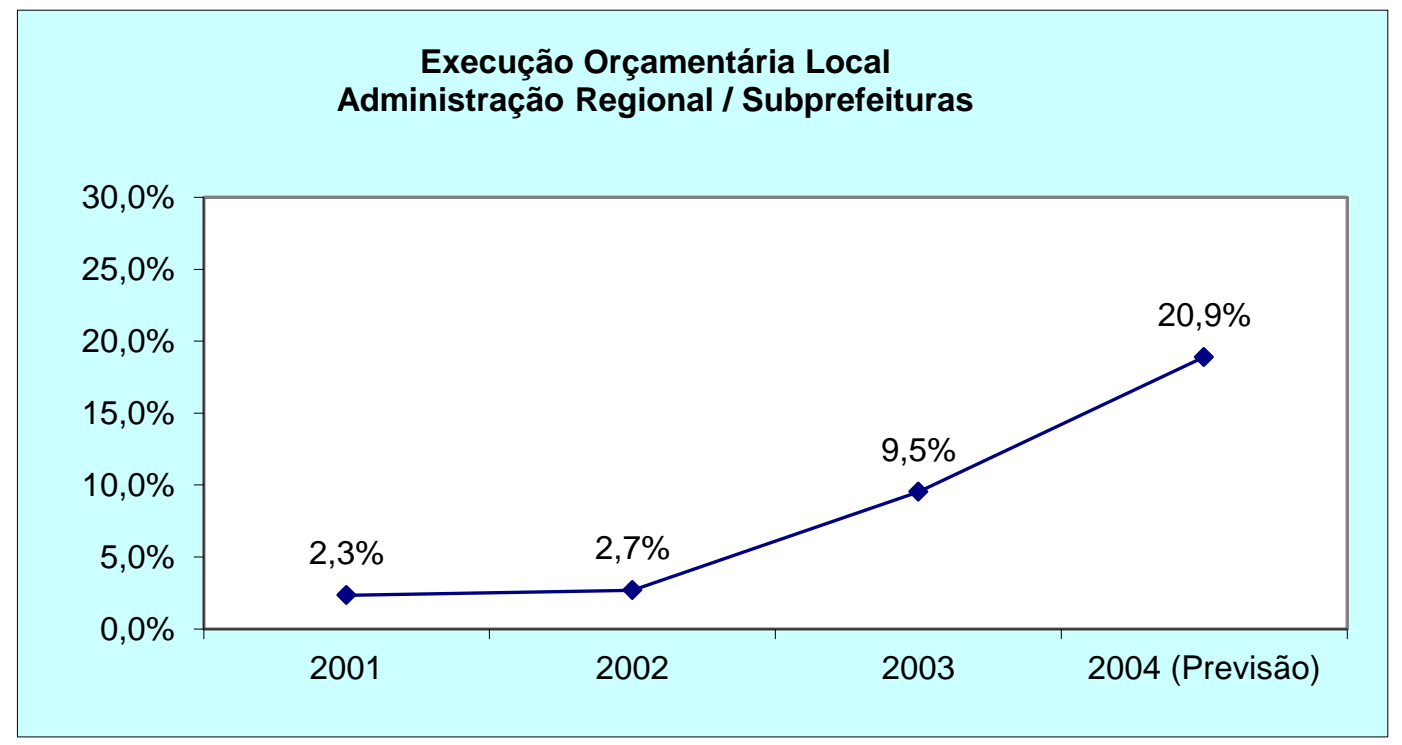

Fonte: site da Prefeitura de São Paulo e Assessoria Técnica de Assuntos Econômicos e Financeiros da Secretaria Municipal das Subprefeituras, junho/2004.

A implantação do modelo de políticas públicas transversais nos territórios se deparou com a desigualdade setorial de recursos orçamentários, o que também foi um obstáculo à descentralização de políticas públicas. Por outro lado, as Coordenadorias de Educação, 
Infraestrutura Urbana e Saúde continuaram a atuar de forma isolada, pois detinham grande parte da verba regionalizada. Em áreas como Assistência Social, organizada via convênios, as Subprefeituras executavam uma política definida na SMAS. Mesmo as áreas novas, como os CEUS (Centros Educacionais Unificados), eram geridas com visões distintas da Educação e da Cultura. A condução da descentralização pelas Secretarias municipais, e não pelas regiões, ainda tinha dois outros problemas. O primeiro, segundo Márcia Barral (informação pessoal) ${ }^{15}$, Subprefeita da Freguesia do Ó, era que o plano de ação das Secretarias e seus critérios de alocação de recursos nem sempre coincidiam com as demandas das regiões.

O segundo, as Secretarias temiam a autonomia das "prefeiturinhas" e a perda de controle político com a descentralização de recursos financeiros. Desse modo, cada Secretaria buscou constituir vínculos diretos com os Coordenadores locais, mesmo que gerassem ações desiguais na descentralização. Na assistência social, por exemplo, a relação direta da SMAS com as Supervisões Regionais, sem a mediação da Coordenadoria regional e do Subprefeito, era a regra. Não ocorreu, portanto, a "intervenção das práticas intersetoriais nas relações de poder já estabelecidas nas estruturas centralizadas" (FERNANDEZ; MENDES, 2004: 17). Pelo contrário, se mantiveram os feudos políticos e organizacionais que Dahl (1989) chama de "pequenas soberanias". Outra face desse problema foi a indefinição sobre a subordinação dos Coordenadores ao Secretário setorial ou ao Subprefeito. Alguns coordenadores, mesmo com autoridade legal sobre os serviços descentralizados, na prática mantinham padrões de comando centralizado ao solicitar autorização às Secretarias. Daí a origem dos conflitos relativos à perda de poder entre Secretários (apegados à gestão desconcentrada) e Subprefeitos (que assumiram a gestão descentralizada). Havia também a disputa na indicação dos Coordenadores: embora o Subprefeito tivesse status de Secretário, e autoridade administrativa para nomeá-los, para as Secretarias a política setorial não podia ser contrariada. Tal situação revela a fragilidade da proposta da descentralização para lidar com os conflitos verticais (Secretarias vs. Subprefeitos) e horizontais (Subprefeito vs. Coordenadores).

Contudo, os Subprefeitos e os Coordenadores foram majoritariamente indicados pelos vereadores. Tanto que a lei 13682/2003, ao definir a estrutura de cargos das Subprefeituras, buscou criar uma salvaguarda nesse mecanismo. Pelo artigo 19, os indicados para as Supervisões de Habitação, Segurança Alimentar, Assistência Social, Cultura, Esportes e Lazer seriam nomeados somente após a oitiva das respectivas Secretarias. Buscava-se reduzir a influência dos vereadores com a avaliação técnica dos candidatos. Esta intenção foi

\footnotetext{
${ }^{15}$ Entrevista ao autor em 19/03/2010.
} 
confirmada por Márcia Barral (informação pessoal) ${ }^{16}$, Chefe de Gabinete da SMAS no biênio 2003/2004 e responsável por coordenar as indicações para as Supervisões de Assistência Social. Pela Lei 13682, os cargos de livre nomeação eram 14: o Subprefeito, o Chefe de Gabinete, cinco assessorias (jurídica, técnica, comunicação, defesa civil e Praça de Atendimento) e sete Coordenadores. Havia ainda 47 cargos de chefia, geralmente ocupados por servidores municipais. As 31 Subprefeituras possuíam 1891 postos diretivos (434 cargos de livre nomeação e 1457 funções de chefia). Esta estrutura serviu de recurso político para o governo ampliar sua coalizão de apoio junto aos vereadores, como será visto a seguir.

\subsection{AS SUBPREFEITURAS E A DEMOCRACIA PARTICIPATIVA REDUZIDA}

No discurso da descentralização, as Subprefeituras também seriam "áreas de poder para repensar as formas de exercer o comando político da cidade". Os instrumentos centrais do modelo de controle social nos territórios deveriam ser o Orçamento Participativo e o Conselho de Representantes eleitos pelos moradores. Será visto que, por motivos distintos, esses dois mecanismos não foram priorizados na estratégia política do governo.

\subsubsection{O lugar limitado do Orçamento Participativo na gestão dos territórios}

O debate sobre a participação popular esteve na agenda do governo desde seu início em 2001, mas a forma como deveria ser implantada era motivo de divergências. Já se observou anteriormente a tese do chefe de gabinete da Secretaria de Governo que defendia a institucionalização das Subprefeituras conforme a distribuição regional do PT na cidade. Mas essa estratégia de poder, através da qual o PT buscaria estreitar seus vínculos com as associações de bairros e movimentos sociais, além de estimular a participação de entidades de base local, foi secundarizada na ação do governo municipal. A importância que os vereadores ganharam como fiadores da governabilidade reduziu o "participacionismo" a um papel politico menor na política do Executivo, a despeito da existência do Orçamento Participativo (doravante chamado OP). Sua implantação ocorreu por se tratar de bandeira histórica de governos petistas, bem como para atender a setores do partido que defendiam essa tese. O OP não deixou de cumprir uma função política importante, pois serviu como instrumento para o PT buscar hegemonizar os movimentos sociais de bairro. Mas, o lugar das entidades de bairro na política do Executivo parece ter ficado mais próximo do que Mollenkopf (1992) chama de a "nova patronagem governamental", ainda que o foco não fosse a transferência de verbas.

\footnotetext{
${ }^{16}$ Entrevista ao autor em 19/03/ 2010.
} 
O OP iniciou sua implantação nos territórios em 2001 e sua gestão cabia à Coordenadoria do Orçamento Participativo (COP), que era vinculada ao Gabinete da Prefeita. Em tese, essa localização da Coordenação poderia revelar seu peso político, mas não foi o que ocorreu. Um exemplo dessa situação é a forma como o governo participava do Conselho do OP. Nesse fórum participavam delegados eleitos pela população para acompanhar a execução orçamentária e fiscalizar a realização das ações aprovadas. Porém, para Vitale (2004: 30),

[...] o expressivo número de conselheiros do governo na composição do Conop ocorre em função da inexistência de uma coordenação-geral de planejamento e da ação de governo. $\mathrm{Na}$ ausência de um órgão responsável pelo planejamento geral, a participação de diversas secretarias no Conselho foi a maneira encontrada para se promover maior integração entre os próprios setores do governo e entre eles e o OP.

Em outras palavras, face à ausência de centralidade política do OP na estratégia de governo, a presença das Secretarias nessa instância parecia ser a forma de se gerar acordos entre os órgãos sobre suas prioridades e desses com os delegados eleitos. Outro problema foi a introdução, em 2002, das plenárias temáticas, pois suas deliberações não se converteram em investimentos específicos e resultaram apenas em diretrizes políticas. Estas metas não indicavam a preferência entre os programas, nem definiam os recursos humanos ou financeiros necessários ${ }^{17}$. O Executivo tinha grande autonomia para priorizar os programas escolhidos pela população e a distribuição de recursos entre as regiões (VITALE, 2004). Portanto, seja nas suas demandas territoriais ou temáticas, a sociedade nem tinha liberdade para decidir onde investir, nem mecanismos de controle sobre as ações do governo.

Mas talvez o principal indicador da baixa prioridade do OP na política de governo foi o reduzido volume de participação no orçamento total da Prefeitura que pouco alterou a alocação do gasto público. Segundo Bello (2006), o Executivo não tinha uma predefinição desse montante, baseada em critérios como parcelas do orçamento previamente não comprometidas com outras despesas ou investimentos. Valendo-se de informações da PMSP, Bello (2006) mostra que o volume de recursos destinado ao OP abrangeu 5\% do orçamento total previsto para 2002 e 6,2\% para 2003. Mesmo que, segundo o autor, tenha havido um aumento de $37 \%$ no período, superior ao crescimento de $10,6 \%$ previsto para os gastos totais, trata-se de um porcentual pequeno se comparado à experiência de Porto Alegre, onde o OP distribuiu de $9 \%$ a $15 \%$ dos recursos totais entre 1991 e 2000. Este é um parâmetro importante, pois exprime a magnitude relativa dos recursos sobre os quais a prefeitura abre mão da sua prerrogativa unilateral de decisão em favor dos processos participativos.

17 O caderno "Programa e Subprogramas de 2003" possuía 139 metas genéricas dos cinco GTs: Cidadania, Inclusão social e Combate à pobreza, Desenvolvimento econômico e Geração de Renda, Habitação e Desenvolvimento Urbano, Saneamento Ambiental e Recursos Hídricos e Transporte e Circulação. 
Paradoxalmente, essa redução do peso orçamentário do OP se ampliou em 2004, após a criação das Subprefeituras. Com o início da implantação das Subprefeituras em 2003, o governo ampliou a discussão do OP para todas as politicas públicas descentralizadas, além de saúde, educação e melhoria de bairro que já eram debatidas desde 2001. Em tese, a ampliação das políticas em debate sinalizava um aumento dos porcentuais orçamentários para deliberação no OP. Contudo, além de não se ampliarem os recursos orçamentários, houve uma piora, pois apenas 4,9\% do orçamento total (redução de R \$ 662 em 2003 milhões para 560 milhões em 2004) foram disponibilizados para decisão de forma participativa. Mesmo com a ampliação do OP para as sete coordenadorias temáticas das Subprefeituras, saúde e educação responderam por 93.9\% em 2003 e 72,9\% em 2004 (BELLO, 2006). As politicas de assistência social, esporte, cultura e meio ambiente responderam, em 2004, por 2,6\% do total deliberado com a participação popular nas Subprefeituras. Com efeito, a participação popular foi conduzida pelas prioridades do Executivo, centrou-se em áreas com mais recursos como saúde e educação, além de não ter ampliado os gastos em outras políticas sociais.

A criação das Subprefeituras não fez do OP um eixo central da política de governo e, contraditoriamente, ampliou o "paroquialismo" democrático limitado aos territórios. Segundo Félix Sanchez, (informação pessoal) ${ }^{18}$, Coordenador do OP no governo municipal, com o debate regionalizado e circunscrito às sete coordenadorias regionais, a eleição de prioridades focou-se ainda mais em solicitações de ordem local e sem uma visão global da cidade. Questões estruturais como controle do tráfego, coordenação metropolitana e execução orçamentária continuaram centralizadas e temas comuns a mais de uma Subprefeitura também não eram itens de deliberação regional. A aproximação do OP da estrutura organizativa das Subprefeituras caminhou na direção contrária à integração de políticas nos territórios e aprofundou a segmentação das demandas por Coordenadoria. Este modelo fragmentado do OP parece evidenciar que tratar da gestão municipal como um todo estava fora de seu escopo, o que também lhe conferia reduzida relevância política na estratégia do governo.

Em se tratando de definir não a importância de se compartilhar o poder, mas quanto e em que grau fazê-lo, o tema tornou-se mais complexo no interior do governo (VITALE, 2004). Para Tatagiba e Teixeira (2005: 7), o estímulo ao OP não o tornou um "item na reforma democrática do Estado e de construção da governabilidade". Também foi distinto do que houve em Porto Alegre onde, segundo Dias (2000), o governo instrumentalizou o confronto do OP (democracia participativa) com a Câmara de Vereadores (democracia

\footnotetext{
${ }^{18}$ Entrevista ao autor em 20/08/2010.
} 
representativa). Em São Paulo, segundo Félix Sanchez, (informação pessoal) ${ }^{19}$, a negociação entre as instâncias do OP e o parlamento não se pautou por essa estratégia. Na gestão dos territórios, a ênfase passou a ser atender, os interesses dos vereadores visando ampliar a coalizão de governo, antes que conferir maior peso aos processos participativos. Estes, no entanto, continuavam centrais para o PT buscar hegemonizar os movimentos sociais de bairro.

Mas os meios da democracia participativa, como assembleias populares nas regiões, também serviram para os vereadores mobilizarem a população para dentro da disputa pela hegemonia política local, como ocorreu na Capela do Socorro, ou serviu para legitimar demandas de vereadores junto às suas clientelas, como ocorreu na Freguesia do Ó. Tais situações parecem reforçar a crítica de Arretche (1996) de que descentralização do poder nem sempre gera democracia e controle social; ao contrário, pode incentivar a patronagem com recursos públicos. A realidade é que o modelo político da participação popular não teve peso na agenda do governo. Na seção seguinte se discute como essa opção política também ocorreu no abandono do Conselho de Representantes para o controle social das Subprefeituras.

\subsubsection{O recuo do governo no debate sobre os Conselhos de Representantes nas regiões}

Os Conselhos de Representantes estão previstos nos artigos 54 e 55 da Lei Orgânica Municipal. Deveriam, conforme a candidata Marta Suplicy (2002: 118-119), servir à população, controlar o Subprefeito e acabar com a influência dos vereadores nos territórios. Para Tadeu Pais, Subprefeito da Capela do Socorro, se as Subprefeituras descentralizariam o Executivo, os Conselhos descentralizariam o parlamento. ${ }^{20}$ Contudo, segundo Félix Sanchez (2006: 55), Coordenador do OP no governo Marta Suplicy,

Como fazer para governar de forma efetivamente democrática? [...]. A ideia das Subprefeituras tinha suas limitações, pois não houve a implementação dos conselhos de representantes como expressão do direito à participação [...] o que, a bem da verdade, também, era um elemento de conflito entre nós. Provavelmente, a ampla coalizão de partidos e parlamentares que sustentava o governo Marta Suplicy não tolerasse essa convivência. Como faríamos, então, para governar com ela: ouvindo a população ou o vereador do bairro ou do distrito?

Na sua estratégia, o governo se orientou pela construção fisiológica da aliança com os vereadores nas regiões. Na barganha com o governo, os parlamentares desmontaram a tese dos Conselhos, visto como um recurso de poder que só beneficiaria o Executivo. Esta decisão política foi construída durante a negociação do projeto de lei das Subprefeituras (setembro de

19 Entrevista ao autor em 20/08/2010. O termo "negociação" foi utilizado para diferenciar a política de enfrentamento com o parlamento, como fora em Porto Alegre, ainda que o Conop pressionasse os vereadores na votação do orçamento para que não fizessem emendas que retirassem verbas do OP.

${ }^{20}$ Entrevista ao autor em 22/04/2010. 
2001-julho de 2002). O Executivo temia que a discussão combinada das Subprefeituras e dos Conselhos de Representantes travasse a votação da primeira, que era prioritária, e limitou o debate para manter o apoio de vereadores contrários aos Conselhos. Estes receavam que os conselheiros atuassem como intermediadores políticos locais e se tornassem lideranças que poderiam ser futuros parlamentares. Os Conselhos foram secundarizados para aprovar as Subprefeituras, apesar de a LOM a atribuir a esses "encaminhar representações ao Executivo e à Câmara Municipal, a respeito de questões relacionadas com o interesse da população local” ${ }^{\prime 21}$. Porém, o mais relevante é que esta discussão expressou a estratégia do governo: implantar as Subprefeituras sem esse instrumento de democracia participativa, em face da prioridade que assumiu a ampliação da política de alianças no parlamento. ${ }^{22}$

O debate sobre os Conselhos teve início em janeiro de 2001, em um projeto da Mesa Diretora da Câmara Municipal, que os concebia como uma instância de democracia participativa, eleita diretamente pelos cidadãos, e complementar à democracia representativa. Não seriam pequenos parlamentos, mas sim canais de participação direta dos cidadãos junto aos poderes Executivo e Legislativo. Na Câmara, o projeto foi alterado, sobretudo, a eleição direta dos 27 conselheiros deu lugar a um órgão em que nove vagas seriam proporcionalmente divididas entre os partidos representados no parlamento. Um terço dos membros seria eleito indiretamente ao ser escolhido pelos diretórios zonais dos partidos. Nesse sentido, para Jilmar Tatto (2006: 315), Secretário de Governo Municipal em 2004, o Executivo tinha

Um timing para aprovar o conselho de representantes das Subprefeituras, medido pela
correlação de forças na Câmara [embora] criticados publicamente por certas
organizações e, quando conseguimos avançar, novas queixas surgiram, pois o
conselho contemplava a participação de representantes dos partidos. Há que se
entender que essa é uma concepção atrasada, pois é inconsequente termos uma
sociedade organizada e um conselho que quer excluir a participação partidária [...].

Mas, na visão inicial do governo, moderna era a participação direta dos cidadãos na vida política dos bairros e retrógrada a interferência dos vereadores nas ARs. Foi o Executivo que mudou de posição e passou a defender a indicação de filiados a partidos, no que parece ter sido mais um recuo diante da pressão dos vereadores. Estes temiam que, com eleições diretas, os movimentos sociais, em geral simpáticos ou aliados ao PT, hegemonizariam os Conselhos como braço de apoio do Executivo nas regiões. Com a indicação partidária, os vereadores poderiam influir nas escolhas dos candidatos nos diretórios zonais.

\footnotetext{
${ }^{21}$ Segundo os vereadores Carlos Neder (PT) e José Mentor (PT), alguns parlamentares condicionavam o apoio às Subprefeituras a não aprovação do Conselho de Representantes. Folha de São Paulo, 04/04/2002.

${ }^{22}$ A vereadora Myryam Athiê (PMDB) declarou à Folha de São Paulo em 04/04/2002: "sou contra o conselho, acho que o conselheiro não pode substituir o vereador, à medida que dou esse poder para ele, qual vai ser o meu papel?" O vereador Antônio Carlos Rodrigues (PL) era “contra o conselho desde o primeiro momento porque acho que ele vai tirar o papel do vereador" (Folha de São Paulo, 16/07/2002).
} 
Sobre a fiscalização, se retiraram três atribuições da lei: a) preparar audiência pública para aprovar Relatório de Avaliação e Fiscalização da Ação Municipal com o Subprefeito e a Comissão de Administração Pública da Câmara e; b) acompanhar, com os delegados do OP, a aplicação do orçamento e; c) a Ouvidoria de Recursos da Cidadania. Para Tadeu Pais (informação pessoal $^{23}$, faltou vontade política do governo para ganhar uma maioria na Câmara favorável a esse novo desenho do Estado na cidade. Após quase quatro anos, o Conselho de Representantes foi aprovado pela lei 13881 (julho de 2004) e regulamentado (decreto 45551/novembro de 2004). A primeira eleição foi marcada para abril de 2005, na gestão seguinte, e nunca ocorreu. Assim, o governo buscou equilibrar interesses conflitantes: atender os movimentos sociais ao formalizar os Conselhos e não confrontar os vereadores ao remeter sua eleição para o outro governo. A próxima seção discute como as Subprefeituras foram o recurso político central para o Executivo ampliar sua política de alianças.

\subsection{A POLÍTICA DE ALIANÇAS E SUBPREFEITURAS NA PARTILHA DO PODER}

Conforme o programa de governo, a forma como os vereadores historicamente se apropriaram das ARs impossibilitava separar o Executivo e o Legislativo na gestão municipal. O Legislativo deveria aprimorar os projetos do governo, fiscalizar o Executivo e tratar de temas globais da cidade. Nas regiões, a gestão, com participação popular e controle social, caberia às Subprefeituras. Mas o governo também atribuía uma importância vital à construção de uma maioria parlamentar para evitar o isolamento sofrido pela gestão Erundina. No início, o governo Marta Suplicy tinha uma bancada de 19 vereadores (16 do PT e 3 do PCdoB), apenas um a mais do que dispunha a gestão Erundina, e se previam dificuldades similares para forjar uma maioria parlamentar. Havia ainda dois vereadores do PSB, partido da exprefeita Luiza Erundina, em tese aliado do governo, mas mais autônomos da estrutura partidária (um apoiado pela Força Sindical; outro pelo bairro Casa Verde) (MARTINS, 2001).

Desde o início de 2002, segundo ano da gestão, dada a dificuldade de aprovar seus projetos no parlamento, o Executivo buscou aumentar sua base aliada com o discurso de um "governo amplo". Até abril de 2002, o governo tinha conseguido o apoio da bancada do PMDB (seis vereadores) e da bancada do PL (três vereadores) com negociações que já envolviam cargos nas ARs. Com o PSB, a base governista de 30 parlamentares se tornou majoritária (a Câmara tem 55 parlamentares). Mas o governo planejava ampliar essa coalizão e a hegemonia no parlamento, para o que a criação das Subprefeituras foi o estímulo

\footnotetext{
${ }^{23}$ Entrevista ao autor em 22/04/2010.
} 
necessário ao trocar apoio por cargos nas regiões. Coube ao Secretário de Governo, Rui Falcão, e ao vereador José Mentor (PT), líder do governo, coordenarem essa negociação.

Mas, os vereadores da coalizão dominante temiam perder influência em seus redutos eleitorais, pois a nomeação dos Subprefeitos pelo Executivo poderia fortalecer as lideranças de bairro. A opção do governo foi franquear a indicação dos Subprefeitos aos vereadores. Assim, ao aprovar as Subprefeituras, o governo também fez desse processo um marco para consolidar sua política de alianças no parlamento a partir de julho de 2002. Mas, desse modo, o Executivo também mostrou que a democracia participativa não seria a prioridade na gestão local e sim a divisão de poder com os vereadores. Esta estratégia foi expressa por Antônio Donato (2006: 41-42), Secretário Municipal das Subprefeituras em 2003, ao dizer que,

[...] do ponto de vista do processo político, depois da Constituição de 1988, o país vive o chamado presidencialismo de coalizão $0^{24}$ : tem-se o parlamento forte, com uma multiplicidade de partidos, o que impõe a necessidade de construir alianças para governar, pois a minoria no parlamento significa um grave problema de governabilidade. A aprovação da lei das Subprefeituras passou por essa discussão, inclusive resultando na participação de partidos aliados na administração das Subprefeituras. Podemos dizer que o governo Marta arquitetou uma maioria parlamentar e o terreno prioritário dos acordos foi o das Subprefeituras.

Esta forma de partilhar o poder com os vereadores nas Subprefeituras se materializou partir do início de 2003. No final do capítulo, a tabela 2.2 mostra como as Subprefeituras serviram para ampliar a coalizão de governo, quando comparada com a divisão política das ARs que, até o final de 2002, retratava centralmente a coalizão eleitoral entre o PT e o PCdoB. Conforme a tabela vê-se que o PT se manteve como o partido majoritário ao ter 74\% dos 31 Subprefeitos (23 regiões) e as outras oito se dividiram entre sete partidos da coalizão de governo. Para os cargos de segundo escalão, com os dados que foram possíveis de coletar, ao menos em 16 locais outros partidos, além da coalizão eleitoral, realizaram indicações. Este processo ocorreu em 52\% das Subprefeituras, mas sem que o PT deixasse de ser majoritário, pois a participação dos aliados foi mais direcionada ao segundo escalão (cargos de Coordenação e Supervisão). Estes geralmente tinham um perfil mais de "bairro" por serem indicados pelos vereadores locais. Assim, o "modelo político" prevalecente nas Subprefeituras se caracterizou por: a) não ser uma entrega das regiões apenas para um partido ou vereador, mesmo que fosse do PT; b) manter a hegemonia e a direção política do PT na

\footnotetext{
${ }^{24}$ Segundo Abranches (1988: 21), o Brasil é o único país que combina proporcionalidade, multipartidarismo e um presidencialismo que organiza o Executivo em grandes coalizões. O "presidencialismo de coalizão" seria consequência desse desenho institucional que exige a distribuição de ministérios segundo critérios partidários e estaduais. Seria uma saída instável para o executivo superar o problema de bases de apoio fragmentadas e o dilema de governar em minoria, além de evitar a paralisia decisória. Assim, constituir uma maioria parlamentar de apoio ao executivo e a participação dos partidos no governo é quase a única saída.
} 
maioria das regiões; c) orientar a participação de aliados em um número menor de locais e em cargos de segundo escalão com menos peso político para incidir na gestão das Subprefeituras.

Para o governo, a composição política nas regiões também serviria para o controle mútuo entre os distintos partidos, pois não haveria apenas um vereador no comando, como nas gestões Maluf e Pitta, mesmo onde o Subprefeito fosse do PT. Por exemplo, em São Miguel Paulista, reduto eleitoral do Secretário Municipal da Habitação, Paulo Teixeira, se indicou Adalberto Dias (PT) para a AR. Com a criação das Subprefeituras, o vereador Paulo Frange (PTB) indicou o Chefe de Gabinete na região. Na Freguesia do Ó, como será visto no capítulo três, o governo aceitou a indicação do Subprefeito pelo vereador José Viviani Ferraz (PL) e manteve as políticas sociais com o PT. Contudo, essa política da partilha de poder nas regiões era de difícil solução: franqueava aos vereadores indicarem os Subprefeitos, mas tentava impedir que os territórios se tornassem feudos de parlamentares. A opção de governar as regiões com os vereadores é confirmada por Jilmar Tatto, Secretário de Governo Municipal em 2004. Para Tatto (2006), o governo errou ao organizar sua coalizão de apoio e isso teve reflexos nas regiões: a) problemas decorrentes da composição da maioria no parlamento, pois as indicações aceitas na cúpula do PT e dos partidos aliados não eram assimiladas nas bases partidárias nos territórios, sobretudo no caso de antigos adversários políticos ${ }^{25}$; b) a pressa em compor a maioria parlamentar gerou conflitos em bairros em que nomeação do Subprefeito não satisfazia as lideranças locais. O Executivo não conseguiu responder aos distintos interesses regionais, especialmente a convivência de grupos políticos às vezes adversários.

A Subprefeitura da Freguesia do Ó ilustra esse desgaste do governo junto aos movimentos sociais ao nomear Walter Alcântara, aliado local do malufismo, como Subprefeito no lugar de Márcia Barral (PT). A Subprefeita era do grupo político do exdeputado federal José Genoíno (PT) e vinculada ao movimento comunitário. Mas, embora o PT não tivesse um vereador com força local, havia nas lideranças políticas tradicionais. Tal situação mostra os limites do projeto de poder do PT que, mesmo dividindo as regiões entre suas correntes internas, não tinha força para hegemonizar todas as Subprefeituras. A saída para a aludida governabilidade foi ceder a Freguesia do Ó para um adversário politico local. No capítulo quatro se discutirá a Subprefeitura de Capela do Socorro que retrata uma realidade distinta, já que a hegemonia da família Tatto manteve inalterado o quadro político local. Nessa situação, a gestão regional teve grande autonomia de ação, pois a partilha interna de poder no PT e no governo chancelou sua continuidade política e administrativa.

\footnotetext{
${ }^{25}$ Além da Freguesia do Ó, também na região da Casa Verde, a família Calvo tinha uma trajetória política de proximidade com o malufismo, apesar de o vereador Rubens Calvo ter se filiado ao PT em 2004.
} 
Tabela 2.2 - Indicações nas ARs (2001/2002) e nas Subprefeituras (2003/2004)

\begin{tabular}{|c|c|c|c|}
\hline \multicolumn{2}{|c|}{$\begin{array}{l}\text { Administrações Regionais } \\
\text { Aliança eleitoral no período 2001/2002 }\end{array}$} & \multicolumn{2}{|c|}{$\begin{array}{c}\text { Subprefeituras } \\
\text { Aliança de governo no período 2003/2004 }\end{array}$} \\
\hline TERRITÓRIOS & $\begin{array}{l}\text { INDICAÇÃO } \\
\text { DO AR }\end{array}$ & $\begin{array}{l}\text { INDICAÇÃO DO } \\
\text { SUBPREFEITO }\end{array}$ & OUTROS CARGOS \\
\hline Aricanduva & Não obtida & Celso Jatene (PTB) & Antônio Rodrigues (PL) \\
\hline Butantã & Sem partido & $\begin{array}{l}\text { Ex-Secretário da Subprefeituras } \\
\text { Antônio Donato (PT) }\end{array}$ & $\begin{array}{l}\text { Sec. Subprefeituras Carlos } \\
\text { Zaratini (PT) }\end{array}$ \\
\hline Campo Limpo & PT & Antônio Rodrigues (PL) & Dep. Vicente Cândido (PT) \\
\hline Casa Verde & PT & Rubens Calvo (PT) & Eliseu Gabriel (PSB) \\
\hline Capela do Socorro & PT & ArselinoTatto (PT) & $\begin{array}{l}\text { Edivaldo Estima }(\mathrm{PPB}) \text {, } \\
\text { Milton Leite (PMDB), } \\
\text { Antônio Goulart (PMDB), }\end{array}$ \\
\hline Cidade Ademar & PT & Dep. Est. Italo Cardoso (PT) & Não obtidas \\
\hline Cidade Tiradentes & Criada em 2002 & $\begin{array}{l}\text { Claudete Alves (PT)/Dep. Fed. } \\
\text { Arlindo Chinaglia (PT) }\end{array}$ & Paulo Frange (PTB) \\
\hline Ermelino Matarazzo & PCdoB & Dep. Ana Martins (PCdoB)/ & $\begin{array}{l}\text { Dep. Devanir Ribeiro (PT)/ } \\
\text { Alcides Amazonas (PCdoB) }\end{array}$ \\
\hline Freguesia do Ó & PT & $\begin{array}{l}\text { Viviani } \\
\text { (PDT) }\end{array}$ & José Américo (PT) \\
\hline Guaianases & PT & Beto Custódio (PT) & José Ferreira (Zelão) (PT) \\
\hline Ipiranga & PT & Dep. Fed. José Mentor (PT) & Jooji Hato (PMDB) \\
\hline Itaim Paulista & PT & João Antônio (PT) & Não obtidas \\
\hline Itaquera & PCdoB & Toninho Paiva (PL) & Adriano Diogo (PT) \\
\hline Jabaquara & PCdoB & Francisco Chagas (PT) & Roger Lin (PSB) \\
\hline Lapa & PT & Augusto Campos (PT) & Paulo Frange (PTB) \\
\hline M'Boi Mirim & Criada em 2002 & Lucila Pizani (PT) & $\begin{array}{l}\text { Milton Leite (PMDB)/Dep. } \\
\text { Vicente Cândido (PT) }\end{array}$ \\
\hline Mooca & PT & Adriano Diogo (PT) & Myriam Athiê (PMDB) \\
\hline Parelheiros & Criada em 2002 & Edivaldo Estima (PPB) & Não obtidas \\
\hline Penha & PT & João Antônio (PT) & Toninho Campanha (PDT) \\
\hline Perus & PT & Raul Cortez (PPS) & Eliseu Gabriel (PSB) \\
\hline Pinheiros & PT & Indicação do Executivo & Não obtidas \\
\hline Pirituba & PT & José Laurindo (PT) & Eliseu Gabriel (PSB) \\
\hline Santana & PT & Carlos Apolinário (PDT) & $\begin{array}{l}\text { Celso Cardoso (PFL)/ } \\
\text { Humberto Martins (PMDB)/ } \\
\text { José Olímpio (PMDB) }\end{array}$ \\
\hline Santo Amaro & PT & Antônio Goulart (PMDB) & Dep. Est. Italo Cardoso (PT) \\
\hline São Mateus & PT & Francisco Chagas (PT) & Dep. Devanir Ribeiro (PT) \\
\hline S. Miguel Paulista & PT & $\begin{array}{l}\text { Paulo Teixeira (Sec. Municipal } \\
\text { de Habitação) }\end{array}$ & $\begin{array}{l}\text { Paulo Frange } \quad \text { (PTB)/João } \\
\text { Antônio (PT) }\end{array}$ \\
\hline Sé & PT & Indicação do executivo & Não obtidas \\
\hline Tremembé/Jaçanã & PT & Dep. José Mentor (PT) & Carlos Apolinário (PDT) \\
\hline VilaPrudente & PT & Flávia Pereira (PT) & Francisco Chagas (PT) \\
\hline Vila Maria & Sem partido & Wadih Mutran (PPB) & $\begin{array}{l}\text { Arselino Tatto (PT)/Manoel } \\
\text { Cruz (PRONA) }\end{array}$ \\
\hline Vila Mariana & PT & José Américo (PT) & Antônio Rodrigues (PL) \\
\hline
\end{tabular}

Fonte: Tabela organizada pelo autor com base em matérias dos jornais Estado de São Paulo de 30/06/2004 e Folha de São Paulo de 29/12/2000, complementada pelas entrevistas realizadas com os Subprefeitos, Coordenadores e Supervisores das Subprefeituras de Capela do Socorro, Freguesia do Ó e São Miguel Paulista. No período 2003-2004 as indicações foram oriundas de vereadores e de deputados, que eram ex-vereadores eleitos em 2000 pertencentes aos partidos da base aliada, e que mantiveram influência política nas regiões. 
Anexo um - MAPA DAS SUBPREFEITURAS

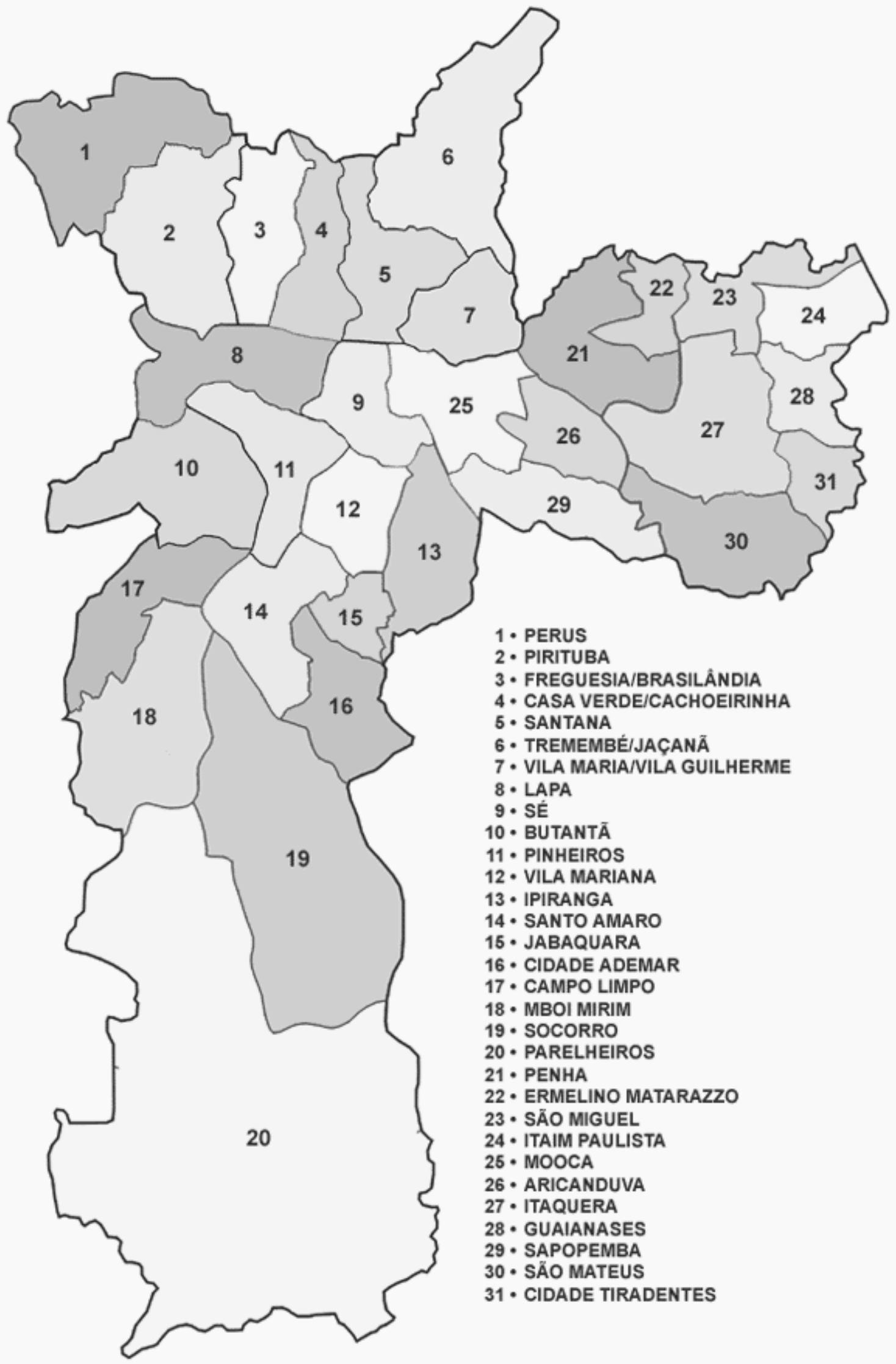


Anexo dois - Organograma das Subprefeituras e os vínculos funcionais com as Secretarias Municipais

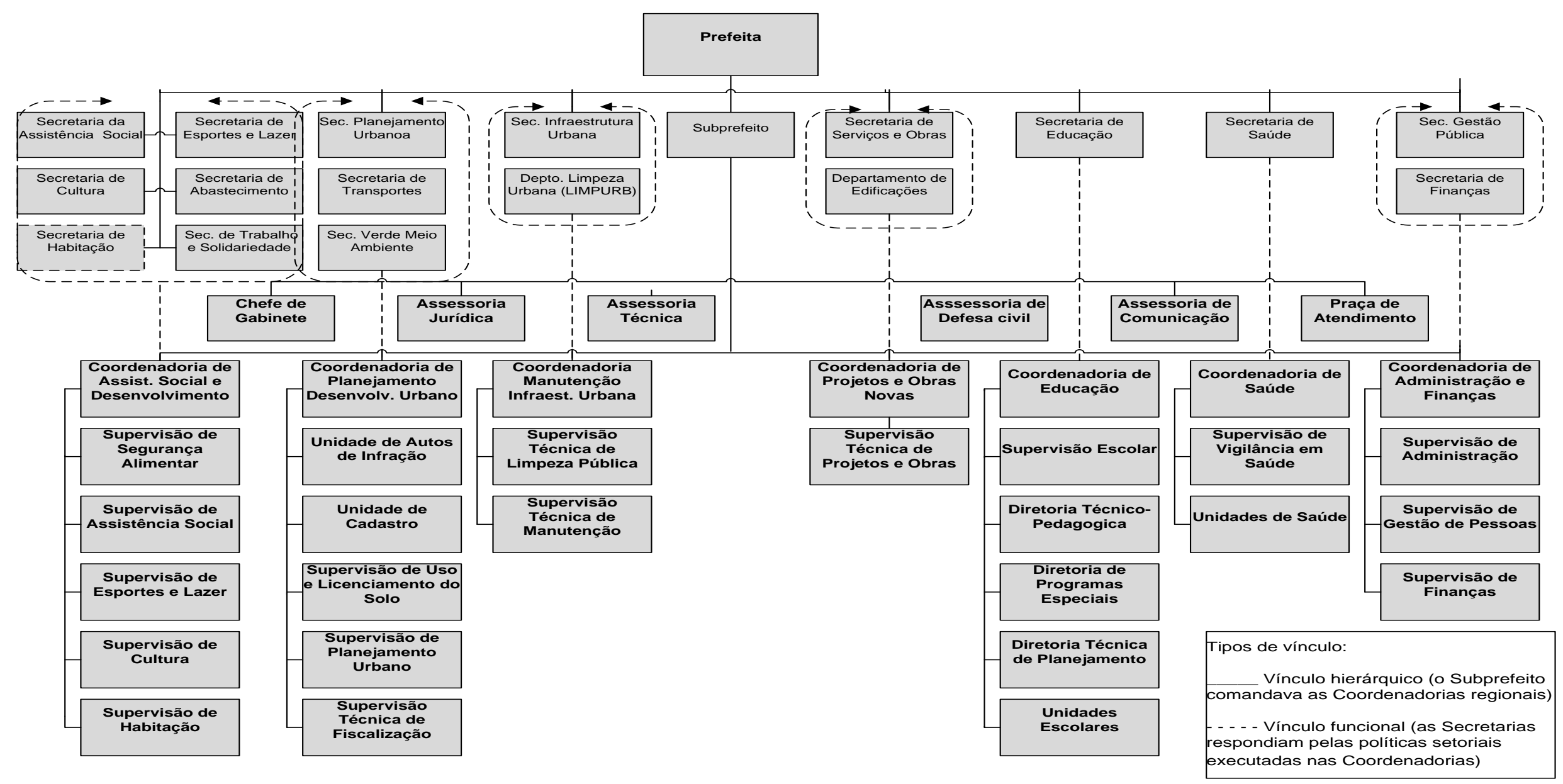

Fonte: Elaboração própria com base na lei 13682/2003 que definiu a estrutura organizacional das Subprefeituras, acrescida das Secretarias municipais relacionadas à descentralização. Nas assessorias do Subprefeito houve uma descentralização menor de atividades: Secretaria de Segurança Urbana (Guarda Civil Metropolitana), Secretaria de Negócios Jurídicos e Secretaria de Comunicação Social. As Secretarias de Governo Municipal e de Relações Internacionais permaneceram centralizadas e as empresas municipais não estavam envolvidas nesse processo que só englobava a administração direta. Antes dessa lei, a regulamentação dos cargos gerenciais e o organograma das Subprefeituras eram disciplinados pela Portaria Intersecretarial n. 6/2002. 


\section{A SUBPREFEITURA DA FREGUESIA DO Ó: A DINÂMICA DA RUPTURA POLÍTICA E A DESCENTRALIZAÇÃO ALTERADA}

Este capítulo apresenta a experiência da Subprefeitura da Freguesia do Ó e a forma como sua direção política foi modificada quando o Executivo a incluiu na negociação com os vereadores para ampliar sua coalizão de apoio. O comando político do PT até o final de 2002 cedeu lugar ao indicado dos vereadores Viviani Ferraz (PL) e Antônio "Baratão" (PL). A discussão busca demonstrar como a descentralização nesse território, a despeito das iniciativas em direção à gestão intersetorial de políticas, enfrentou resistências das Secretarias municipais, conforme foi visto no capítulo dois. Esta dificuldade foi intensificada com a divisão política da Subprefeitura entre o PT e os vereadores do PL, o que reforçou a atuação isolada de cada área e amplificou o caráter errático da descentralização administrativa. A falta de diálogo entre os dois campos políticos opostos foi uma variável central que condicionou as características que assumiu a gestão local. Por outro lado, a prioridade do Executivo de governar com os vereadores locais evidenciou que os processos de democracia participativa existentes na região, como o OP, não foram relevantes na sua estratégia política.

\subsection{INTRODUÇÃO}

A Subprefeitura é formada pelos distritos de Brasilândia e da Freguesia do Ó e, em 2004, tinha uma população de 392.251 habitantes. Conforme a PMSP (2004), o primeiro distrito possuía um IDH de 0.432 e o segundo um índice de 0,525. Dentre os 96 distritos da cidade, e num ranking onde a exclusão social máxima era-1,00, a Brasilândia era $010^{\circ}$ pior distrito com o índice de $-0,814$ e a Freguesia do Ó ocupava $56^{\circ}$ lugar com $-0,233$. Pelo Censo Demográfico (2000), 12,92\% das famílias não tinham rendimento e 55,75\% percebiam até cinco salários mínimos. A região tinha 22 áreas de risco (na cidade havia 192) e 101 favelas (na cidade havia 2018) e tais indicadores exemplificam as carências sociais dessa região.

A Freguesia do Ó, assim como toda a zona norte da cidade, sempre foi um importante reduto malufista. Quando Paulo Maluf se elegeu prefeito 1992, cinco vereadores da sua coligação tiveram suas maiores votações na zona norte, e dois desses no distrito de Nossa Senhora do Ó. Um dos vereadores, José Viviani Ferraz (PL), assumiu o controle da AR da Freguesia do Ó. Mas o administrador por ele indicado se envolveu em denúncias de cobrança de propina ao tolerar o comércio clandestino. O novo administrador, Walter Alcântara, que assumiu em maio de 1995, era funcionário público municipal e vizinho de Viviani Ferraz, 
embora a indicação não fosse admitida pelo parlamentar. Em 1997, já no governo Celso Pitta, este vereador foi agraciado com outra regional na zona norte: a de Perus (TEIXEIRA, 2004).

Na região, conforme Barral (1994), militante petista local, na década 70, surgiram movimentos voltados à melhoria das condições de vida. Com a fundação do diretório do MDB (Movimento Democrático Brasileiro), partido de oposição ao regime militar e hegemonizado por militantes do PCdoB, se intensificou a organização popular. A Freguesia do Ó foi a primeira região da cidade em que os movimentos sociais lançaram candidatos à Câmara Municipal em 1976. O MDB passou a ser o polo aglutinador das lutas locais até 1980 quando, com a fundação do PT (Partido dos Trabalhadores), as lideranças locais optaram por esse novo partido para intensificar os vínculos com os movimentos populares. Contou nesse processo a ação da esquerda da Igreja Católica, simpática à teologia da libertação e seu apoio às comunidades de base. É nesse período que os movimentos sociais se fortaleceram no confronto com o governo Maluf. Desde então, a política local é bastante polarizada entre o PT e as organizações populares e os vereadores e lideranças políticas apoiadoras do malufismo.

\subsection{O PAPEL DO GOVERNO LOCAL COM A DIREÇÃO POLÍTICA DO PT}

Em 2001, antes do Decreto de março de 2002 que instituiu os "Governos Locais", a Freguesia do Ó já havia implantado um processo similar. A Administradora Regional, Márcia Barral, tinha sido Chefe de Gabinete dessa AR na gestão Luiza Erundina. Segundo os entrevistados, as ações que não fossem acordadas nesse fórum tinham pouca chance de serem aprovadas, pois o objetivo era reduzir as ações isoladas das políticas setoriais. Buscava-se aproximar as iniciativas gerais de governo, como os programas sociais, e as necessidades do território, na construção integrada de políticas. Para Mirca Bonano, Supervisora de Cultura, foi importante que todos os órgãos participassem de ações como cadastramento de programas sociais, de ações de combate à dengue ou de atividades da Defesa Civil para ampliar a interlocução com os problemas locais (informação pessoal) ${ }^{26}$.

Conforme os entrevistados, o objetivo era criar um conhecimento mútuo das políticas para integrar os diversos enfoques em uma compreensão comum do território. A característica dos gestores regionais favoráveis ao modelo de intervenção integrada parece ter contribuído para a implantação do "Governo Local”. Inclusive ajudou a fortalecer Secretarias que não tinham uma política definida para a cidade, como na área da cultura, em que se partiu da realidade dos territórios para organizá-la como politica municipal. Ao que parece, pois, esse

\footnotetext{
${ }^{26}$ Entrevista ao autor em 08/06/2010.
} 
processo coletivo de gestão foi uma marca positiva nos dois primeiros anos da gestão, até o final de 2002, mas que não se manteve partir de 2003, como será visto mais adiante.

No entanto, o "Governo Local" enfrentou dificuldades por ser uma reunião informal de representantes das Secretarias municipais e esbarrar na impossibilidade de decidir sobre a utilização dos orçamentos setoriais que se mantinham centralizados. Para os entrevistados, este foi um problema da desconcentração encetada pelo "Governo Local", pois inexistia a gestão regional do orçamento. Os integrantes do Governo Local tinham que submeter suas discussões às respectivas Secretarias para que essas decidissem se aceitavam ou não as ações localmente concebidas. Este fluxo decorria dos limites decisórios desse fórum desconcentrado, além de refletir o baixo interesse das Secretarias em incentivá-lo. Havia um desencontro entre a demanda local e as políticas setoriais, afora o temor das Secretarias no avanço da descentralização administrativa. O desacordo também ocorreu, segundo Márcia Barral (informação pessoal) ${ }^{27}$, pela dificuldade de se romperem os diferentes olhares setoriais sobre o território. Esta situação foi mais perceptível na área de infraestrutura urbana com sua baixa participação no “Governo Local”, segundo Tereza Nakagawa (informação pessoal) ${ }^{28}$, representante local da Secretaria de Desenvolvimento, Trabalho e Solidariedade (SDTS). O esforço de integração se limitou às políticas sociais que viriam a se aglutinar na Coordenadoria de Assistência Social, a partir de 2003. A ação autônoma dos serviços urbanos que já eram executadas na AR se manteve, apesar dos esforços de integração local.

Havia também a necessidade de compatibilizar as demandas imediatas do bairro, como a manutenção de ruas, com o programa de governo para a cidade que ocorreu na implantação dos programas sociais. Por exemplo, em 2001, o programa Renda Mínima ${ }^{29}$ da SDTS requeria o cadastro das famílias a serem beneficiadas. Segundo Luiz Brito (informação pessoal) ${ }^{30}$, Coordenador local do OP indicado pelo Administrador Regional da Vila Mariana e suplente de vereador, José Américo (PT), se formou um comitê com representantes locais das Secretarias para implantar um programa considerado uma "vitrine do governo". Sobretudo, porque o distrito de Brasilândia, pelos critérios de exclusão social, foi um dos três primeiros selecionados a implantar essa ação de caráter redistributivo. Esta iniciativa buscou ampliar a visibilidade do "Governo Local" junto à população e aos movimentos sociais, em face da centralização orçamentária e prioridade políticas das Secretarias sobre as demandas da região.

\footnotetext{
${ }^{27}$ Entrevista ao autor em 19/03/2010.

${ }^{28}$ Entrevista ao autor em 03/08/2010.

${ }^{29}$ O Programa de Garantia de Renda Familiar Mínima Municipal era voltado às famílias com renda per capita inferior a meio salário mínimo, desde que mantivessem seus filhos de 0 a 15 anos na escola.

${ }^{30}$ Entrevistaao autor em 04/05/2010.
} 
Em relação ao OP, coube ao "Governo Local” a sua implantação a partir de 2001. Contudo, segundo Luiz Brito (informação pessoal) ${ }^{31}$, nesse processo, houve três problemas: a) não havia porcentual definido de orçamento para tratar das prioridades votadas pela população; b) reuniam-se as entidades para colher e sistematizar as propostas das assembleias populares, mas a análise técnica era centralizada nas Secretarias; c) a partir de 2002 houve dificuldades de execução do orçamento do ano anterior, o que "embaralhou o processo, pois as lideranças que participaram do primeiro [ano] já vieram para o segundo [ano] com pouco crédito". Em 2002 se receava que o acréscimo do tema de melhorias urbanas, além de educação e saúde já presentes desde 2001, não permitiria assumir novos compromissos com a população, diante dos limites orçamentários do OP. Desse modo, a AR passou a conferir relevância a ações como o programa Bolsa Trabalho ${ }^{32}$ da SDTS para "compensar" os limites do OP. Como este programa também se relacionava com associações de moradores, buscouse minimizar o descrédito com o OP. Ainda assim, segundo Luiz Brito (informação pessoal) ${ }^{33}$, o “Governo Local” realizava reuniões de bairro para mobilizar a população, pois,

[...] isso aproxima e faz a população perceber a presença do poder público indiscriminadamente, embora na visão [da população] ainda tenha essa coisa clientelista do vereador. Ai a gente dizia: não tem vereador aqui e sim o poder público. E isso foi tão importante para ganhar credibilidade [através dessa] relação direta com o cidadão sem interferência política.

Para o Coordenador do OP, o objetivo era opor-se às práticas políticas dos vereadores e lideranças tradicionais da região na sua relação com a população. Porém, a despeito da retórica da democracia participativa, o que se buscava era estreitar a relação direta da AR com os movimentos sociais, o que os aproximava do governo e de vereadores do PT com atuação local. Dentre os parlamentares petistas na região estava o vereador José Laurindo, que obteve $52.8 \%$ de seus votos nas ARs de Pirituba e Freguesia do Ó nas eleições de 2000, além do deputado estadual Henrique Pacheco. Em 2001, ambos apoiaram a criação da União dos Movimentos de Moradia (UMM), entidade que passou a ocupar a maioria dos assentos no Conselho Regional da Política Habitacional, afora sua forte inserção no OP e, em 2004, na elaboração do Plano Diretor local. Esta associação era o movimento social mais articulado da região e pressionava o poder público para solucionar os problemas de áreas de risco e assentamentos precários. Portanto, o suporte dos parlamentares esteve longe de ser isento de interesses, pois auxiliava o PT local a buscar a hegemonia na UMM, cuja atuação mobilizava

\footnotetext{
${ }^{31}$ Entrevista ao autor em 04/05/2010.

${ }^{32}$ Programa voltado ao público de 16 a 20 anos, oriundo de famílias de baixa renda, e que visava ampliar sua escolaridade e capacitação, além de integrar o jovem no bairro com a realização de atividades comunitárias.

${ }^{33}$ Entrevista ao autor em 04/05/2010.
} 
a sociedade para o OP. Dada a intermediação dos parlamentares, a relação do "Governo Local" com a população não era desprovida de "interferência política", como sugere o Coordenador do OP. O PT buscava ampliar sua hegemonia junto aos movimentos sociais e a instalação de processos participativos foi importante para instrumentalizar essa ação política.

Até dezembro de 2002, a direção política da Subprefeitura foi partilhada entre as correntes internas do PT. Em janeiro de 2003 assumiu o Subprefeito indicado pelos vereadores Viviani Ferraz (PL) e Antônio "Baratão" (PL). O primeiro recebeu 55,5\% de seus 20.114 votos na Freguesia do Ó e o segundo obteve 22,6\% de seus 2.023 votos nesse bairro. O novo Subprefeito, Walter Alcântara, administrara a regional na gestão Paulo Maluf e sua trajetória política não era marcada por vínculos com os movimentos sociais. ${ }^{34}$ Tal mudança representou uma ruptura com o projeto político em vigor na região e contrariava a concepção de regionais cuja gestão seria afastada da influência dos vereadores. O Executivo, ao incluir a região na negociação com os parlamentares, secundarizou a relação com o PT local dada a prioridade que assumiram a política de alianças na Câmara Municipal e a formação de um "governo amplo". A barganha fisiológica, criticada pelos petistas como prática malufista, foi central para o governo partilhar a Subprefeitura com esses vereadores, afora buscar hegemonizá-los diante do ocaso do malufismo na cidade. Esta forma de ampliar a coalizão governamental coincide com a abordagem de Dahl (1989) que foi discutida no Capítulo 1.

O PT local perdeu suporte institucional e seus espaços de poder na região, visto que a gestão da Subprefeitura era, até então, dividida entre suas correntes internas. Além do mais, como todos os vereadores de base local, também os petistas buscavam manter suas áreas de influência, conforme Kuschnir (2000), para o que os vínculos políticos com a Subprefeitura facilitavam a defesa de seus interesses. A redução da influência dos vereadores petistas e do partido nesse local ajuda a explicar a crítica do PT ao fisiologismo. Talvez, como ocorreu em São Miguel Paulista, se a composição política mantivesse a hegemonia petista na Subprefeitura, e os canais de relacionamento com os vereadores do partido, ela não fosse avaliada como fisiológica, mas aceita como uma contingência da política de alianças.

Segundo Márcia Barral (informação pessoal) ${ }^{35}$, a demanda dos vereadores "querendo as Subprefeituras" não deveria ser feita nas regiões, pois o Subprefeito era a voz local da Prefeita e a expressão pública do governo. A coalizão de apoio no parlamento deveria ser construída com outros meios, como obras solicitadas pelos vereadores e cargos menores, mas

\footnotetext{
${ }^{34}$ À Folha de São Paulo (15/09/2000), a candidata Marta Suplicy disse que os Subprefeitos não precisariam ser filiados ao PT, mas ter "afinidades ideológicas" [...], pois "não posso colocar um simpatizante do malufismo como administrador regional".

${ }^{35}$ Entrevista ao autor em 19/03/2010.
} 
não com funções executivas e de relação direta com a população. Infere-se, pois, que a Subprefeitura deveria ou manter a partilha interna restrita ao PT, ou ser uma composição política sob a hegemonia petista. Mas a divisão política da Subprefeitura acentuou o caráter errático da descentralização administrativa e fez recuar os tímidos esforços que buscavam uma atuação mais integrada no território. A próxima seção discute esse período da nova gestão na Subprefeitura entre os anos de 2003 e 2004.

\subsection{A NOVA DIREÇÃO POLÍTICA COM SEUS HÁBITOS TRADICIONAIS}

O PT local entendia que o Executivo, para governar e aprovar seus projetos, necessitava de aliados. Na trajetória da política municipal isso significava lidar com a barganha fisiológica dos vereadores, sobretudo nas Subprefeituras em que se encontravam suas clientelas eleitorais. Esta foi a realidade da Freguesia do Ó quando o governo negociou o apoio de vereadores em troca de cargos na região. Para Márcia Barral, (informação pessoal) ${ }^{36}$,

A pressão se dava para votar questões na Câmara, era exatamente isso. Todo vereador que tem uma Subprefeitura na mão é um instrumento poderoso e transforma pequenas coisas como uma generosidade ou pequenos favores. [...] Afora as questões de trambicagem com corrupção, que era o caso dos vereadores da Freguesia do Ó onde tinha processo e denúncia [...].

Para os petistas locais, o Executivo errou ao confundir a gestão da cidade com a relevância conferida à construção da governabilidade, que teve como contrapartida conviver com o fisiologismo e o clientelismo que já existira na AR nos governos Maluf e Pitta. Assim, segundo essa crítica, as Subprefeituras não tinham nada de novo a apresentar à população. Nesse contexto, a resposta das Coordenadorias vinculadas ao PT foi opor-se ao Subprefeito por considerá-lo um histórico adversário malufista. Para os petistas, o movimento popular sofreu uma derrota política com o seu afastamento da Subprefeitura. Na realidade, o partido perdeu os recursos políticos e institucionais que alimentavam seu projeto local de poder apoiado nos movimentos sociais. Prevaleceu a opção do Executivo de governar com os vereadores, conforme destacado por Walter Alcântara (informação pessoal) ${ }^{37}$

[...] A indicação é sempre política e sempre será assim, e ai não é um problema a indicação do vereador da região, pois ele fiscaliza até mesmo o Subprefeito se ele agir mal [...]. Vereador é votado para ser alguém a favor do povo que deve ter no vereador o seu apoio como se fosse representante distrital e ai entra a indicação do Subprefeito.

\footnotetext{
${ }^{36}$ Entrevista ao autor em 19/03/2010.

${ }^{37}$ Entrevista ao autor em 14/04/2010. Sobre as indicações dos vereadores, o Subprefeito disse à Folha de São Paulo (10/01/2003): "Eu não vejo problema nisso porque ninguém melhor do que um vereador da região para saber dos problemas dos bairros". O Subprefeito creditou sua indicação aos vereadores José Viviani Ferraz (PL) e Antônio Baratão (PL), sobretudo o primeiro "porque ele é da região. É um vereador que vota com a prefeita, né? O Baratão, que também é da região, também vota[com o governo]". Na entrevista a esse pesquisador o Subprefeito confirmou que sua indicação foi oriunda dos dois vereadores.
} 
A fala do Subprefeito é contrária ao discurso do PT de se apoiar na participação popular para reduzir a influência dos vereadores nas regiões. Nesse caso, a concepção petista se aproximava do que Dahl (1989), conforme discutido no capítulo 1, chama de "deliberadamente criar" a participação dos cidadãos de modo conveniente aos interesses do governo. Sobretudo, para o PT, o parlamentar não poderia ser o único intermediário das demandas da população, que deveria se apoiar no Conselho de Representantes para realizar o controle social das Subprefeituras. Para o grupo político que assumiu a Subprefeitura, o objetivo era fortalecer o mandato dos parlamentares. Tanto que os vereadores Viviani Ferraz e Baratão tinham escritórios políticos na região que eram a porta de entrada para a população solicitar serviços como tapa buraco, limpeza de boca de lobo etc. Para o PT, tal intermediação clientelista do vereador deveria acabar, tanto que no início da gestão de Márcia Barral na AR, o discurso era que não haveria mais "coronelismo, que ninguém mandava mais". A intervenção do Executivo na região, além de não combater, se apoiou na manutenção do fisiologismo e do paroquialismo dos vereadores que o PT criticava como método de gestão.

Afora a ênfase mais direta na lógica da vereança na administração da Subprefeitura, os malufistas ainda a concebiam como uma AR melhorada, ao priorizar as atividades de manutenção urbana na base do "quebrou arruma". A descentralização de políticas era estranha ao vereador Viviani Ferraz, pois sua referência era a gestão da AR no governo Maluf e Pitta. Assim, a forma como se deu a divisão política da Subprefeitura, aprofundou o caráter errático da descentralização administrativa, pois as ênfases diferenciadas de intervenção no território entre o PT e o grupo político do novo Subprefeito não tinham nenhuma integração interna.

A tarefa de buscar a mediação política entre os dois grupos coube a Genilson da Silva Santos (simpatizante do PT) e que, como Assessor Técnico da Câmara Municipal, participara da articulação para construir a coalizão de governo. Na região, conhecia os vereadores Baratão e Viviani Ferraz, aspecto que o núcleo político do governo considerou útil para defender, junto ao PT local, que o novo Subprefeito representava a bancada do governo no parlamento. Mas se na Câmara esses vereadores votavam com o governo, na região se mantinham adversários políticos do PT. Mesmo com essa disputa no interior da Subprefeitura, o Executivo dizia que não interferiria na gestão local, pois lhe interessava aprovar os grandes projetos para a cidade. Daí a tarefa desse assessor visando atenuar a crítica petista de que o Executivo fizera concessões a vereadores malufistas, bem como a importância que assumiu a lógica da vereança no bairro. Sobre a forma como o Executivo construiu sua coalizão de 
apoio, Genilson Silva (informação pessoal) ${ }^{38}$, que se tornou Chefe de Gabinete de Walter Alcântara, disse que

O maior mito que existe na população é porque a principal ideia é que o vereador quer
ir para o governo em troca de cargos e benefícios. Na verdade a primeira conversa que
houve com os vereadores foi em troca de trabalho na base de cada um. O vereador
quando é eleito tem uma cobrança da base muito forte. [...] Então ele traz um
compromisso de campanha de asfalto, iluminação, e ele quer resolver e ai, a priori, ele
pensa: se eu fizer parte da base do governo eu vou ter acesso a esses serviços. Então a
primeira conversa que tem é essa: olha, eu ajudo a Marta a governar, mas eu quero
resolver os problemas da canalização do córrego, da rua asfaltada, iluminação da
viela. Então essa é a conversa que tem. O tempo vai passando e esse vereador vai
tendo outro entendimento, né. É um processo. Ah, mas o Subprefeito de lá não tá me
atendendo, eu mandei um ofício, carta, passou um mês e ele não me atendeu, não dá
retorno. Ai ele pede para a Marta trocar o Subprefeito. Ai com o tempo ele pensa: eu
posso colocar alguém meu e o cara começa a atender a minha base. Então é uma
evolução: então o cara começa pedindo para a base dele, pede para trocar o
Subprefeito e depois ele quer uma cara que atenda a base dele. Por isso começa essa
discussão todo ano. Muitas vezes o cara tá lá, vota com o governo e cria uma situação,
passa a ser oposição para poder criar o diálogo e gerar uma situação. Mas, na prática
começa a partir disso que é atender a demanda da base dele.

Esta fala reflete o "cotidiano da política" que Kuschnir (2000) sintetiza no conceito de acesso como prerrogativa que o vereador com bases eleitorais locais adquire ao participar da coalizão de apoio do governo municipal. Segundo a autora, o vereador precisa delimitar sua área, apoiada na divisão de regiões de influência patrocinada pelo Executivo, e na indicação de cargos na localidade. Assim, participação na base do governo e o atendimento à sua base eleitoral se alimentam mutuamente. Este "toma-lá-da-cá" da política era criticado pelo PT local, mas aceito como normal enquanto envolveu apenas seus grupos internos e os vínculos com os seus vereadores com o argumento de que só esse partido representava o governo.

Para os entrevistados vinculados ao PT, o novo Subprefeito privilegiava o atendimento às clientelas políticas dos vereadores que o indicaram. Segundo Ana Vellardi (informação pessoal) ${ }^{39}$, “não havia projeto político da Subprefeitura que não fosse atender o seu partido e dos vereadores que se aliaram ao governo como moeda de troca como a direita sempre fez em nome da governabilidade". Para os petistas tal política era a antítese da participação popular, ainda que esse partido a instrumentalizasse para buscar hegemonizar os movimentos sociais. Com efeito, o PT local não admitia ter sofrido uma derrota política justamente com as regras do jogo da democracia representativa: quem tem mandato parlamentar, como os vereadores, possui legitimidade política para barganhar sua participação no governo, pois têm votos necessários para aprovar os projetos governamentais. Os movimentos sociais, o ator político central para o modelo da democracia participativa, nada decidem na arena parlamentar.

\footnotetext{
${ }^{38}$ Entrevista ao autor em 16/06/2010.

${ }^{39}$ Entrevista ao autor em 05/05/2010.
} 
A clivagem política na Subprefeitura expressava duas visões distintas sobre como construir a hegemonia local. Um exemplo singelo dessas diferentes concepções se expressou na organização da festa da Brasilândia. Com o PT o evento foi levado para uma área mais carente, se instituiu um conselho para organizá-la e os vereadores não discursavam. Quando o novo Subprefeito assume, a festa voltou a ocorrer na rua mais importante do bairro e apenas os vereadores tradicionais do bairro falavam. Este episódio retrata duas formas de decisão política (o conselho participativo vs. a decisão centralizada do Subprefeito) e dois modos distintos para fortalecer a atuação parlamentar (vereadores do PT através das entidades locais que organizavam a festa $v s$. vereadores tradicionais através do apoio direto do Subprefeito por eles indicado). Essa última passou a ser a lógica da vereança hegemônica a partir de 2003.

A mudança da direção política da Subprefeitura dividiu-a em dois blocos: o PT manteve as coordenadorias de políticas sociais (educação, trabalho, cultura, assistência social, habitação), excetuado esporte que permaneceu com o PCdoB; os vereadores Viviani Ferraz e Baratão indicaram os coordenadores de obras, serviços urbanos e administração. Com este acordo o PT continuou a gerenciar áreas vistas como vitrine do governo e capazes de inovar na gestão intersetorial de políticas. Para os dois vereadores importava ocupar as áreas de serviços urbanos, especialmente Viviani Ferraz que já tinha sua rede de contatos na AR desde o governo Maluf. Na próxima seção se discute os efeitos dessa divisão na Subprefeitura.

\subsection{A GESTÃo DA POLÍTICA E A POLÍTICA NA GESTÃo NO TERRITÓRIO}

Como já destacado no capítulo dois, a divisão política das Subprefeituras criou mecanismos informais de fiscalização mútua entre os partidos. Para o PT, segundo Luiz Brito (informação pessoal) ${ }^{40}$, “o desafio era trabalhar com eles até para fiscalizá-los.” Este processo partidarizou a administração, pois os dois campos políticos se valiam disso como meio para avaliar o desempenho das atividades. Conforme Genilson da Silva (informação pessoal) ${ }^{41}$,

A prefeita deixava claro que independente da indicação política, se alguém pisasse na
bola [...] manda o cara embora [...] e falava: se o cara não tá servindo, avisa o vereador
que ele não serve. Ai a gente aproveitava e dizia: pisou na bola a gente vai levar para a
Marta e ela vai mandar você embora ou seu político vai escolher outro. Então a gente
dava essa pressão como um mecanismo para fazer os caras andarem na linha.

Para o Executivo, este controle mútuo atuaria em favor da eficiência administrativa, já que ambos os grupos políticos evitariam cometer erros. Porém, se objetivo era evitar a hegemonia territorial de apenas um vereador, não impediu o surgimento de feudos políticos na gestão. Nos serviços urbanos (corte de grama, limpeza de boca de lobo etc.), porta de

\footnotetext{
${ }^{40}$ Entrevista ao autorem 04/05/2010.

${ }^{41}$ Entrevista ao autor em 16/06/2010.
} 
entrada da maioria das demandas da população, os vereadores Viviani Ferraz e Baratão mantinham a política dos pequenos favores. Por terem indicado os Coordenadores, buscavam estabelecer vínculos diretos com as chefias visando definir as regiões a serem atendidas. Para os vereadores, dificuldades em encaminhar suas solicitações, sobretudo burlar a programação dos serviços, eram vistas como uma situação onde o indicado havia "virado a casaca". Em tais situações, os vereadores pressionavam o Subprefeito para substituir as chefias.

Nas políticas sociais, a organização territorial da assistência se deu quando a Lei Orgânica da Assistência Social (LOAS) a definia como garantidora de direitos e não mais como política compensatória. Na região, os vereadores tradicionais sempre lidaram com a população de forma assistencialista ao distribuir cadeiras de roda, cestas básicas, próteses etc. Para opor-se a esse modelo, a SMAS padronizou os editais de convênios, centralizou sua homologação junto às ONGs prestadoras de serviço e "carimbou" as verbas a serem descentralizadas, visando impedir sua utilização discricionária pelo Subprefeito. Porém, este e os vereadores que o indicaram, desejavam ter o controle pleno da política da assistência, e não apenas a gestão desconcentrada de questões administrativas. Como foi visto no capítulo dois, a demora em descentralizar essa política pública foi justificada para evitar sua fragmentação regional. Sobretudo, a utilização das verbas pelo Subprefeito em ações que não fossem as prioridades da área. Os recursos financeiros permaneceram na SMAS, a despeito da reivindicação do Subprefeito de que não tinha como incidir nas diretrizes da política.

A Assistência Social, ao discordar da descentralização promovida pelo Executivo, buscou se organizar autonomamente nos territórios. A realidade política local amplificou tal disposição, pois às divergências existentes se somou o confronto sobre a natureza assistencialista ou afirmativa das ações. Pelo organograma das Subprefeituras, a área se subordinava à Coordenadoria de Assistência Social e Desenvolvimento (CASD), cujo titular na região era indicado pelo vereador Baratão; enquanto o Supervisor, subordinado a esse Coordenador, era simpatizante do PT. Como o PT comandava a SMAS, os vínculos entre a Secretaria e o Supervisor eram diretos. Assim, afora as divergências partidárias, houve conflitos de autoridade do Coordenador com a SMAS e o Supervisor. Este último atuava sem consentimento do Subprefeito, pois se sentia politicamente respaldado pela SMAS e buscava, através de vínculos pessoais e partidários, deliberar sobre temas técnicos. Na prática, a CASD e o Subprefeito não tinham ascendência política e gerencial sobre a área. Para Hogwood e Gunn (1993), essa situação mostra que a implantação de políticas não é perfeita, pois: a) quem tem autoridade não necessariamente tem poder e obtém aquiescência; e b) a comunicação e a 
coordenação de políticas se tornam difíceis face à departamentalização e ações de grupos com seus próprios valores, objetivos e interesses.

$\mathrm{Na}$ área da cultura ocorreram problemas de gestão, pois, segundo Mirca Bonano, (informação pessoal) $^{42}$, Supervisora de Cultura, confundiu-se militância partidária e profissionalismo gerencial para implantar uma nova visão de política pública. As inovações na descentralização da cultura acabaram limitadas pela forma como se nomearam os cargos de Supervisor regional, geralmente desprovidos de capacidade técnica, em face da interferência das indicações políticas. Neste processo houve conflitos de autoridade entre o Subprefeito (gestor regional) e o Secretário (gestor da política): de quem era a "maior caneta" para nomear? O Subprefeito tinha esse poder formal, e geralmente o fazia respaldado pelos vereadores, apesar do acordo informal de que o Secretário tinha que avalizar o candidato. Quando o parecer setorial era negativo se criava um impasse político, além de inexistir respaldo legal para essa situação que gerava entraves administrativos para a área. Este conflito também ocorria na implantação da política, pois a visão descentralizada e participativa de promoção da cultura oriunda da Secretaria nem sempre era aceita pelo Subprefeito.

Também houve dificuldades gerenciais e de formação da agenda dessa política quando a Subprefeitura assumiu as atividades, mas o orçamento continuou centralizado na Secretaria. Enquanto o Subprefeito buscava ampliar as verbas para realizar shows e eventos, a Secretaria enfatizava que a prioridade era a formação de público. Criou-se um problema para a direção da política, pois a definição setorial era desconsiderada pelo Subprefeito. Tais impasses ilustram as lacunas de procedimentos na descentralização quando ocorriam conflitos de autoridade entre as demandas locais e uma política setorial.

Para a política cultural, os CEUS (Centros Educacionais Unificados) eram considerados vitais. Este era um espaço que integrava atividades escolares (ensino do primeiro ao nono ano), esportivas (piscinas e quadras esportivas) e culturais (teatro múltiplo uso, ateliês, estúdios, biblioteca e telecentros). Como o orçamento era da Secretaria da Educação, mas seria gerenciado pela Secretaria da Cultura, houve problemas de coordenação. Além disso, as duas Secretarias tinham compreensões distintas sobre a utilização do equipamento para atividades culturais como shows, pois a rotina escolar se distinguia desses eventos. Para a Cultura, havia uma visão corporativa e inflexível; para a Educação, se desconsiderava a rotina administrativa da escola. Como no território educação e cultura permaneceram com o PT, tais conflitos indicam que houve divergências sobre a

\footnotetext{
${ }^{42}$ Entrevista ao autor em 21/05/2010.
} 
descentralização também no campo petista e, ainda que existisse um comitê gestor do CEU, foi ineficaz para mediar o debate. Ademais, conforme Mirca Bonano (informação pessoal) ${ }^{43}, a$ indicação de pessoas inexperientes inviabilizou a construção da política cultural, pois,

\begin{abstract}
Os referenciais teóricos [...] foram totalmente abandonados e não se tinha mais gestores competentes para coordenar esses processos. [...] Ao invés de criar uma ação descentralizada se criou uma relação autoritária em alguns lugares [...] onde os Subprefeitos tinham mais cacife político por serem amparados por vereadores [...]. Na Freguesia do Ó foi uma região onde se sofreu uma debandada dessa ordem, uma rasteira política, e o projeto inicial se perdeu. Tudo ficou funcionando, a Casa de Cultura, o CEU, mas se perdeu o sentido de criar um novo jeito de fazer gestão pública na cidade.
\end{abstract}

A área cultural retrata os impasses organizativos das políticas setoriais no território. De um lado, para ter autonomia de ação, a Supervisão de Cultura se reportava diretamente à Secretaria, vinculada ao PT, e não ao superior local da CASD. Por outro lado, o setor se fragmentou porque a Supervisão não controlava as indicações dos cargos no CEU. Conforme Genilson da Silva (informação pessoal) ${ }^{44}$, as indicações políticas não visualizavam a capacidade das pessoas, embora a estruturação da Subprefeitura demandasse gestores mais qualificados para implantá-las. A divisão política da Subprefeitura afetou sua organização administrativa, pois os nomeados, que careciam de capacidade técnica, se respaldavam na representação do político que o indicou. Este processo gerou uma confusão entre funções gerenciais e ação político-partidária e influenciou no caráter errático da descentralização. Tal situação também expressava outro conflito de autoridade: os nomeados deveriam prestar contas ao vereador que o indicou ou ao Subprefeito como seu superior formal? Este duplo comando, além de gerar problemas organizacionais, contribuiu para manter os feudos setoriais de influência dos parlamentares Viviani Ferraz e Baratão e dos grupos internos do PT.

Este processo teve impacto na gestão das políticas, especialmente na sua construção intersetorial. Para exemplificar, o Grupo de Trabalho Ampliado Bairro Legal Brasilândia funcionou de outubro de 2002 a junho de 2003 apoiando um programa da Secretaria Municipal de Habitação. O GT era formado por representantes da assistência social, educação, saúde, trabalho, cultura, esportes, verde e meio ambiente, serviços urbanos e limpeza pública. Com suas premissas metodológicas de articulação intersetorial e de participação social, parece que essa foi uma iniciativa exitosa em gerar um diagnóstico urbano e habitacional. A gestão integrada, remanescente do "Governo Local", buscava "superar o movimento inercial de uma estrutura institucional cristalizada em ações setoriais e estanques."

\footnotetext{
${ }^{43}$ Entrevista ao autor em 08/06/2010.

${ }^{44}$ Entrevista ao autor em 16/06/2010.
} 
Contudo, o apoio à operacionalização do GT foi descontinuado por duas razões: a) reproduziu a clivagem política interna à Subprefeitura entre políticas sociais e políticas urbanas; b) em 2003, a transição do "Governo Local” para as Subprefeituras se deparou com o temor das Secretarias de perderem poder e orçamento. A luta política entre os grupos petistas e as diferentes políticas setoriais para a descentralização minaram a sua continuidade.

No plano organizativo, o grupo político que assumiu a Subprefeitura manteve em funcionamento o comitê de gestão intersetorial formado pelo Subprefeito, Coordenadores e Supervisores. Porém, os dois campos políticos opostos se autonomizaram nas suas ações. As políticas sociais buscaram manter-se integradas, pois era um meio de o PT articular a oposição ao Subprefeito. Este, com base em um acordo tácito com o PT, pouco intervia nessas áreas, pois sua prioridade estava nos serviços urbanos mais visíveis e de retorno político mais imediato para os vereadores que o indicaram. Assim, além da gestão urbana e a gestão social serem historicamente separadas nos territórios, a divisão política na Subprefeitura inviabilizou sua atuação conjunta. Intensificou-se a fragmentação das políticas e os fóruns intersetoriais se transformaram em instâncias meramente protocolares. As áreas com maiores orçamentos como educação, que era do PT, e infraestrutura, comandada pelo vereador Viviani Ferraz, por exemplo, priorizavam suas ações setoriais. Por isso, o "Governo Local”, apesar de ter limites decisórios como instância desconcentrada, foi uma referência para a construção coletiva de definições, pois havia representantes das políticas setoriais nas suas reuniões. Com a sua descontinuidade, não apenas a lógica setorial prevaleceu, como piorou em relação ao período da AR, pois havia um número maior de políticas descentralizadas agindo de forma isolada.

Também ocorreu do Subprefeito, ao não conseguir aprovar suas demandas no comitê de gestão, buscar a negociação direta com os Secretários municipais para responder a oposição interna do PT local. Esta situação se exemplifica no acordo realizado com a Secretaria Municipal de Esportes, que era do PCdoB, e a Supervisão local vinculada ao deputado federal Aldo Rebelo. O Subprefeito planejava construir uma quadra de esportes na região e sua proposta não foi aceita no debate com as demais coordenadorias, sobretudo as comandadas pelo PT. O Subprefeito, então, articulou com a pasta dos esportes, contrariamente à decisão local. Iniciativas dessa ordem também influenciaram para que ações setoriais tivessem primazia sobre a construção intersetorial de políticas no território.

Igualmente com o PT o Subprefeito construiu vínculos diretos, particularmente com a Coordenadoria de Educação. A titular, indicada pelo Diretório Zonal do partido, era a mesma desde a gestão de Márcia Barral e foi a única Coordenadoria em que o PT ficou à frente quando novo Subprefeito assumiu. Na Assistência Social os petistas mantiveram as 
Supervisões, enquanto na área da Saúde houve várias trocas de direção, todas influenciadas pelo vereador Viviani Ferraz, embora houvesse pessoas ligadas ao vereador Carlos Neder (PT). A aproximação da Educação com o Subprefeito foi criticada pelos petistas com o argumento de que reforçava a ação de históricos adversários políticos locais; mas, para a Coordenadora, o Subprefeito demonstrava ter sintonia com o Executivo. A composição interna da área educacional passou a ter influência da Secretária Municipal de Educação, Cida Peres. À época, seu marido, Carlos Zaratini, Secretário Municipal de Transportes e, em 2004, o último Secretário das Subprefeituras, era uma figura proeminente do grupo ligado ao Secretário de Governo, Rui Falcão, responsável pela política de alianças do governo. Para os petistas originários do "Governo Local”, a educação, ao constatar que a antiga direção política se desfez, priorizou seus projetos em detrimento da oposição ao Subprefeito. Esta disputa política influiu na gestão e é bem ilustrada por Tereza Nakagawa (informação pessoal) ${ }^{45}$

As políticas intersetoriais funcionaram bem com as Secretarias que se davam bem como Educação e Assistência [...]. Não juntou todas por causa da tendência política de cada setor, não eram todos do PT e se fosse assim teria mais chance de dar certo. Como era composição política, tinha [...] partidos diferenciados e não dava muita liga.

O antagonismo partidário influiu no caráter errático da descentralização ao confundir a disputa política com a gestão e dificultar ao Subprefeito exercer a coordenação geral. Tal situação, somada às distintas dinâmicas das políticas setoriais nas Secretarias, reiterou a fragmentação das ações. A participação popular, outro vetor do projeto das Subprefeituras, também se deparou com essa clivagem política e será discutida na próxima seção.

\subsection{A PARTICIPAÇÃO POPULAR E A LÓGICA DA VEREANÇA}

A divisão política na Subprefeitura também se refletiu na implantação do OP. Para Márcia Barral (informação pessoal) ${ }^{46}$, este "passou a ter uma linha mais de cooptação das entidades da sociedade civil com pequenos favores, ao invés de um caminho emancipador, de enfrentamento de conflitos e busca de consensos, que é a base da participação popular." A fala de Luiz Brito ${ }^{47}$ é mais esclarecedora a esse respeito: o "OP sofreu uma descontinuidade na sua visão [...] e se diluiu a ideia do OP que não era petista e passou a ser mais protocolar". Para Ana Vellardi (informação pessoal) ${ }^{48}$, era como se o movimento popular tivesse "perdido força orgânica e acesso ao governo, houve um retrocesso, as entidades voltaram a bater na porta das Secretarias e perdeu sentido o governo local e a descentralização".

\footnotetext{
${ }^{45}$ Entrevista ao autor em 03/08/2010.

${ }^{46}$ Entrevista ao autor em 19/03/2010.

${ }^{47}$ Entrevista ao autor em 04/05/2010.

${ }^{48}$ Entrevista ao autor em 05/05/2010.
} 
O que se infere das falas acima é que havia um cálculo político do PT que visava consolidar o partido junto aos movimentos sociais, para o que o OP era estratégico, conforme Dias (2000). Assim, é difícil aceitar que existisse uma relação direta do poder público com a população sem interferência de atores políticos, como vereadores com atuação local, o PT local e o próprio núcleo diretivo da Subprefeitura. Tanto que o PT, ao perder a direção política da Subprefeitura, entendia que o OP havia sido descontinuado; ou seja, se ressentia desse instrumento na relação com os movimentos sociais. Como já visto anteriormente, a triangulação entre partido, governo e entidades como a UMM se quebrou, pois a nova direção política da Subprefeitura se vinculava a outras associações no bairro. Portanto, se a orientação política do OP pode ter alterado seu conteúdo com o grupo vinculado ao vereador Viviani Ferraz à frente, sua estrutura e funcionamento foram mantidos, mesmo porque essa era uma ação coordenada pela COP, ligada ao Gabinete da Prefeita. Nesse contexto, a interlocução direta das entidades vinculadas ao PT com as Secretarias comandadas pelo partido foi uma saída para a perda de apoio da Subprefeitura. Esta forma de ação era uma contradição com a tese petista do poder local autônomo, mas foi aceita visando apoiar os movimentos sociais com recursos financeiros e organizativos para que mantivessem sua "força orgânica".

Estes vínculos também evidenciavam que os movimentos populares eram importantes para a disputa política local que as Secretarias comandadas pelo PT travavam contra o Subprefeito. Mas, agindo dessa forma, as Secretarias também criaram vínculos diretos com as entidades locais sem a mediação das Coordenadorias comandadas pelo partido na Subprefeitura. Este foi o caso da Habitação, uma das mais resistentes contra a descentralização de atribuições às Subprefeituras. Mesmo antes da troca de direção na Subprefeitura, os compromissos da SEHAB com Associações de Moradores já priorizavam ações de regularização fundiária sem debatê-las no OP. Este é um exemplo de como o processo participativo se direcionava para demandas que não conflitassem com os acordos políticos das Secretarias com as localidades, além de reduzir a verba deliberada no OP.

Outra restrição ao processo participativo era o poder discricionário das Secretarias nos pareceres técnicos das questões aprovadas nas assembleias locais e a seletividade nas escolhas regionais para atender tais reivindicações. $\mathrm{Na}$ área habitacional, por exemplo, a região norte não era prioridade, visto que o Secretário tinha sua base política na zona leste. Esta forma de patronagem com recursos públicos, a rigor, em nada diferiu do clientelismo criticado pelo PT como modus operandi dos vereadores malufistas. Assim, com as solicitações regionalmente feitas no OP, mas com a decisão de viabilidade técnica e financeira centralizada, havia uma grande margem de manobra para a decisão política. Na Freguesia do Ó, a principal demanda 
era urbanização que, mesmo aprovada no OP, não foi atendida. Prevaleceu o programa de regularização fundiária da Secretaria sob o argumento de que a habitação de interesse social era a prioridade e a deliberação do OP ficou condicionada à agenda setorial dessa política. Conforme o Subprefeito Walter Alcântara, quando o governo tinha interesse em certas ações, induzia a população a debatê-las para legitimá-las de forma "participativa", à la Dahl.

Ao mesmo tempo, o Subprefeito Walter Alcântara (informação pessoal) ${ }^{49}$ expressava outra visão do processo político local enfatizando o papel dos vereadores. Para ele, "o atendimento com pedido dos vereadores sempre teve prioridade, pois são eles quem essencialmente encaminham tudo e como o Subprefeito de uma região deve compor seu orçamento [...]". Aqui se identifica outro cálculo politico, voltado a fortalecer os parlamentares com influência no bairro, mas sem a orientação política de aproximar o partido dos movimentos populares, como era o caso dos vereadores do PT. O modelo de gestão se pautava pela lógica da vereança, tal como foi a opção do Executivo para essa região.

O OP se transformou em um espaço de disputa do PT com o grupo político do Subprefeito, a quem se atribuía ter "aparelhado" a participação popular e impedido a democratização da política ao aproximá-la das entidades simpáticas aos vereadores que o indicaram. Contudo, o apoio do vereador José Laurindo à UMM, para o PT, era considerado um meio "de estimular a organização da entidade" sem "interesses políticos". Com a perda do comando da Subprefeitura, e o afastamento na condução do OP, o PT teve mais dificuldade em manter seus vínculos com os movimentos sociais. O partido sempre se julgou o efetivo representante das "causas populares" em oposição às lideranças políticas tradicionais. Desse modo, é compreensível a disputa politica que se gerou na Subprefeitura com a mudança de comando e que acabou se estendendo para o movimento social articulado pelo PT.

Nesse sentido, uma alternativa foi mobilizar entidades comunitárias, como a UMM, para a disputa nas instâncias de participação, como ocorreu na elaboração do Plano Diretor Regional, conforme Ana Vellardi (informação pessoal) ${ }^{50}$ : “os compromissos do Subprefeito era com outro grupo que não a população e numa plenária os coordenadores defenderam uma proposta junto com às lideranças populares e o Subprefeito estava em outro lado com os empreendedores. Não houve acordo com a diretriz do Subprefeito, disputamos e ganhamos [...] um absurdo político". As políticas sociais também articulavam as entidades locais antes das assembleias do OP, pois, segundo Francisco Rodrigues (informação pessoal), ${ }^{51}$

\footnotetext{
${ }^{49}$ Entrevista ao autor em 14/04/2010.

${ }^{50}$ Entrevista ao autor em 05/05/2010.

${ }^{51}$ Entrevista ao autor em 12/05/2010.
} 
[...] o Subprefeito apoiava no OP o que lhe interessava que era asfalto para os vereadores, e era diferente do resto das políticas; e ai o próprio governo disputava dentro do OP. [...] O Subprefeito ficava descolado disso, embora devesse ser o condutor, pois os interesses eram diferentes. [Havia] disputa dentro do OP em torno de prioridades da Subprefeitura contra os interesses dos movimentos que se viam desrespeitados, pois participavam do Governo Local e, na hora do OP o Subprefeito apresentava outras prioridades, interesses dos vereadores [...]. O Subprefeito se apropriava do OP para atingir seus objetivos que era ter voto para seus políticos.

A situação acima também revela uma mudança de comportamento dos atores políticos em relação ao OP. Antes de 2003, o vereador Viviani Ferraz (PL) mobilizava entidades a participar das assembleias populares para pressionar o governo local e desgastar a gestão petista na AR propondo questões fora do escopo do OP. Também era uma forma de criticar a relação do PT com as entidades visando impedir que os vereadores fossem a porta de entrada das solicitações da população. Após 2003, quando a condução política do OP deixa de ser do PT, esse passa a mobilizar as entidades politicamente próximas a participar das assembleias como forma de disputar suas demandas e pressionar a nova gestão da Subprefeitura. Em dois períodos diferentes, atores políticos distintos se valem de estratégias similares na mesma instância participativa para se legitimarem diante de entidades politicamente próximas.

O OP também sofria tentativas de burla pelos vereadores, do PT e da oposição, pois se suas demandas, mobilizadas ou não através das entidades, deixassem de ser aprovadas as encaminhavam através de emenda orçamentária. Este expediente era possível, já que o OP não definia valores exatos de investimento nas regiões, o que permitia ajustes na hora de votar a Lei Orçamentária no parlamento. Era grande a margem de manobra do Executivo para incorporar ou não as demandas deliberadas nas assembleias populares, o que favorecia a política da "negociação" com a Câmara Municipal, como foi discutido no capítulo dois. Como relataram alguns entrevistados, "havia uma briga com o Executivo para levar em conta mais o OP que os vereadores." Este é mais um exemplo da irrelevância da democracia participativa na estratégia política do Executivo. A barganha dos vereadores para atender suas clientelas nos territórios é legítima, pois foram eleitos pela população local. Contudo, a forma como o governo atendeu tais demandas enfraqueceu o discurso petista de implantar uma reforma democrática na relação entre o Estado e a Sociedade. Sobretudo, em relação à visão normativa da complementaridade entre o caráter representativo e participativo da democracia.

Em relação às políticas setoriais, o OP teve resultados distintos, mas tímidos em termos orçamentários e de retorno objetivo, conforme a discussão realizada no capítulo dois. $\mathrm{Na}$ assistência social, além de se articular com as demais Coordenadorias para confrontar o Subprefeito, não se implantaram novos serviços. Os que existiam na região continuavam a ser 
mantidos com os recursos financeiros de convênios centralizados na SMAS. A mobilização das lideranças comunitárias parece ter sido o saldo mais importante para debater essa política. $\mathrm{Na}$ área da cultura, o saldo positivo foi a influência local nas definições da política do Executivo para o setor. Segundo Mirca Bonano (informação pessoal) ${ }^{52}$, o OP temático possibilitou enxergar a necessidade de um orçamento da política cultural, considerando a realidade regional, e formas de viabilizar a utilização das Casas de Cultura. Contudo, foi um debate para formular diretrizes e sem resultados concretos para o bairro. Na área da educação, segundo Elza Ramello (informação pessoal ${ }^{53}$, as reivindicações eram articuladas juntamente com os Conselhos Escolares para serem propostas no OP. Apesar de algumas propostas terem sido aprovadas, por razões políticas e técnicas, muitas foram atendidas apenas no governo José Serra, como um CEU previsto desde 2003, mas implantado apenas em 2006.

A experiência da Subprefeitura da Freguesia do Ó mostra como a mudança de direção política alterou o curso da descentralização. O novo arranjo de forças promovido pelo Executivo retirou do PT a hegemonia da regional e gerou impactos na política local e em sua organização política e administrativa. Sobretudo, na relação petista com os movimentos sociais que perderam o apoio institucional do poder público. Como os vereadores e lideranças políticas tradicionais voltaram a ocupar o comando da regional, se instalou outro processo político na região. A forma como o Executivo incluiu a região na sua estratégia de governabilidade, considerada a grande prioridade do núcleo dirigente do governo, estabeleceu as regras do jogo para a ação dos atores políticos. Com a existência de dois grupos políticos adversários na Subprefeitura, a disputa interna pelo seu controle passou a ser a característica central da realidade local. Com a derrota política do PT, que enfraqueceu sua presença na região, o malufismo ganhou uma sobrevida no território, e essa alteração na correlação de forças se refletiu na gestão da Subprefeitura. Administrativamente intensificou o caráter errático e fragmentado da descentralização, pois a divisão política interna reforçou as distintas dinâmicas setoriais sem nenhuma perspectiva de integração no território. Politicamente, com a prioridade conferida à lógica da vereança, os processos participativos, como o OP, perderam a pouca relevância que tinham. Tal situação parece evidenciar que o projeto da descentralização com participação popular foi estruturado para ser controlado apenas pelo PT, cujas contradições foram expostas na Freguesia do Ó. Sobretudo, suscita dúvidas se o Conselho de Representantes era mais do que discurso político, pois, se fosse implantado, a sociedade poderia decidir contrariamente aos interesses do PT e do governo na região.

\footnotetext{
${ }^{52}$ Entrevista ao autor em 08/06/2010.

${ }^{53}$ Ramello, E. Mensagem recebida por elzaramello@yahoo.com.br em 25 abr.2010.
} 


\section{A SUBPREFEITURA DA CAPELA DO SOCORRO: A DINÂMICA DA HEGEMONIA POLÍTICA E A DESCENTRALIZAÇÃO CONTINUADA}

Este capítulo apresenta a experiência da Subprefeitura da Capela do Socorro e a forma como a descentralização foi implantada, face à continuidade da sua direção política sob a hegemonia da família Tatto, grupo petista local. Ainda que tenha existido uma composição com vereadores do PMDB e PPS, não houve a entrega de poder em áreas chave. A influência política dos Tatto se estendia também à sua participação no núcleo de governo. Tal situação, ao invés de fortalecer a descentralização na região, ampliou a resistências das Secretarias municipais temerosas de perder espaço político para esse grupo. Esta realidade se intensificou com a perda da coordenação da descentralização no Executivo, que era de Jilmar Tatto, e criou disputas políticas das Secretarias com a Subprefeitura em torno das atividades e recursos a serem repassados ao território. Um dos efeitos negativos dessa luta política interna ao governo foi influenciar para que a descentralização fosse errática e dependente da atuação de cada Secretaria. Por outro lado, a despeito da prioridade local para o OP e outros fóruns similares, a democracia participativa não se consolidou como centro da gestão no território.

\subsection{INTRODUÇÃO}

A Subprefeitura é formada pelos distritos de Socorro, Cidade Dutra e Grajaú e, em 2004, era a mais populosa com 563.922 mil habitantes. Segundo a PMSP (2004), o primeiro distrito possuía um IDH de 0,628 , o segundo um índice de 0,469 , e no terceiro era de 0,419 . O terceiro, dentre os 96 distritos da cidade, e em um ranking onde a exclusão social máxima era $-1,00$, apresentava o $2^{\circ}$ pior índice de exclusão social com $-0,985$ e tinha cerca de $60 \%$ da população da Subprefeitura; o segundo ocupava o $25^{\circ}$ lugar com - 0,541 e 34\% da população. O distrito de Socorro era o menos desfavorecido com um índice de exclusão social de 0,031. Pelo Censo de 2000, 16,09\% das famílias não tinham rendimento e 57,01\% recebiam até cinco salários mínimos. A região tinha 33 áreas de risco (de 192 na cidade) e 221 favelas (de 2018 na cidade), o que também a caracterizava como uma área socialmente carente.

A maior força política local era o grupo petista da família Tatto. Já na gestão Erundina, Leonide Tatto fora o administrador regional. Em 2000, o vereador Arselino Tatto se reelegeu para o quarto mandato consecutivo com 38,5\% de seus votos na região e em 2003 foi eleito presidente da Câmara Municipal. Em 1998, o irmão Jilmar Tatto se elegeu deputado estadual com grande votação local. Outro irmão, Ênio Tatto, se elegeu deputado estadual em 
2002 com a terceira maior votação da legenda. A família comandava o Diretório Zonal do PT, além de ter forte presença na máquina petista municipal onde os irmãos Jair e Leonide eram, respectivamente, secretário de organização e tesoureiro. No governo Marta Suplicy, Jilmar Tatto foi titular da pasta de Abastecimento (2001), da SIS (2002), do transporte (2003) e da Secretaria de Governo (2004). A força política da família também pode ser medida pela presença de Jilmar Tatto no núcleo político do governo e pelo controle de 40 cargos na Subprefeitura da Capela do Socorro. O grupo ainda tinha influência nas Subprefeituras de Campo Limpo e Vila Maria, além da Secretaria de Abastecimento, Empresa Municipal de Urbanização e Banco do Povo (Folha de São Paulo, 16/12/2002; 23/07/2004).

Em 2002, a AR foi desmembrada para se criar a Subprefeitura de Parelheiros, que passou a ser área de influência do vereador Edivaldo Estima (sem partido), mas reeleito em 2000 pelo PPB. Desde 1992 esse parlamentar concentrou seu peso eleitoral no bairro (em 2000 foram 60\% dos 29.716 votos recebidos). Na gestão Paulo Maluf assumiu o controle dessa AR, entre 1994 e 1996, e na gestão Celso Pitta fez parte da coligação governista. Outro parlamentar influente na região era Antônio Goulart (PMDB) que, em 2000, obteve 35\% de seus 27.582 votos na Capela do Socorro. ${ }^{54} \mathrm{Na}$ gestão Marta Suplicy, além de participar da administração na região, indicou o Subprefeito de Santo Amaro. Também o vereador Milton Leite (PMDB), que recebeu 8,1\% de seus 39.716 votos na região, foi contemplado com cargos, além da Subprefeitura de M'Boi Mirim, sua maior base eleitoral. Os três foram da base aliada de Celso Pitta e contrários à investigação da "máfia da propina" nas ARs em 1999.

Por ser próxima ao ABC Paulista, a Capela se tornou um local de moradia para os trabalhadores das empresas e os movimentos sociais locais foram influenciados pelas lutas operárias desencadeadas no final dos anos 70 naquela região. Ademais, a região de Santo Amaro, da qual Capela do Socorro se separou como AR em 1985, era um centro industrial e com grande contingente de trabalhadores assalariados. Esse foi um dos motivos do adensamento demográfico na década de 70 e do surgimento de loteamentos clandestinos. É nesse contexto que o PT e a família Tatto crescem politicamente junto aos movimentos de moradia e comunidades eclesiais de base. Mas, os vereadores Edivaldo Estima, Milton Leite e Antônio Goulart, mantiveram seu espaço político na região e, mesmo com a hegemonia local da família Tatto, o Executivo municipal os agraciou com cargos na Subprefeitura para ampliar sua base aliada. A seguir se aborda o início da descentralização na região.

\footnotetext{
${ }^{54}$ Para a Folha de São Paulo, 19/07/ 2002, o vereador Antônio Goulart (PMDB) disse ter apoiado o governo "dada a relevância das Subprefeituras para a cidade" e completou dizendo que "em todo governo, há composições e alianças de partidos para garantir a governabilidade. Em São Paulo não poderia ser diferente".
} 


\subsection{O INÍCIO DA DESCENTRALIZAÇÃO COM O NÚCLEO INTERSECRETARIAL DA CAPELA DO SOCORRO (NICS)}

Em fevereiro de 2001 foi instituído o Núcleo Intersecretarial da Capela do Socorro (NICS), o primeiro passo da descentralização. O Administrador Regional, Tadeu Pais, tinha sido Chefe de Gabinete da AR na gestão Luiza Erundina e convivera com a experiência dos Governos Locais. Com o NICS se buscou reproduzir a mesma forma de organização junto aos órgãos municipais, visando planejar políticas públicas locais. Dezesseis órgãos indicaram representantes para esse Núcleo, cuja tarefa era estudar a realidade socioeconômica local e construir uma análise integrada do território. Coube ao NICS assumir ações de governo como a implantação dos programas sociais, com ênfase para o programa Renda Mínima que cadastrou cerca de 30\% dos beneficiários do município em 2001. Mas o maior objetivo do Núcleo era preparar a Capela para implantar as Subprefeituras, de modo que o planejamento de ações focou-se no que propor quando a AR fosse chamada para discutir a descentralização. Esta parece ter sido uma particularidade local que assentou as bases institucionais para implantar o Governo Local a partir de março de 2002 e, posteriormente, a Subprefeitura.

O NICS era um encontro informal de representantes das Secretarias, que não eram nomeados e dependiam de decisões e orçamento centralizados. Conforme os entrevistados foi uma experiência positiva de aprendizado de políticas, no sentido dado ao termo por Sabatier (1993), em face de seu debate intersetorial para conhecer a região. Contou em favor do Núcleo o perfil do administrador regional e de técnicos com atuação prévia na região dispostos a atuar de forma integrada. A existência de uma assessoria de planejamento contribuiu para integrar as ações do NICS. Contudo, não parece que, como afirmam Silva et alii (2006), após a criação das Subprefeituras, tenha se mantido a articulação entre as políticas públicas dada a primazia que assumiu a organização de cada setor, como será visto adiante.

O NICS não era uma estrutura de governo, mas foi bem avaliado pelos entrevistados por considerá-lo relevante para apresentar demandas para os órgãos centrais decidirem no que investir. Este fórum se desfez com a implantação da Subprefeitura, pois a formalização das Coordenadorias setoriais se deparou com as resistências das Secretarias municipais em repassar atividades e recursos e com a barganha dos vereadores por cargos. Mas, conforme Juan Fernandez (informação pessoal) ${ }^{55}$, assessor técnico do Subprefeito, já na AR os cargos políticos de assessoria eram pouco participativos nas atividades do NICS, pois a "ação dos assessores era mais de caráter político-partidária, era claríssimo, $[. .$.$] eram dois mundos que$

\footnotetext{
${ }^{55}$ Entrevista ao autor em 21/06/2010
} 
não se falavam". Mesmo que a construção de ações integradas possa ter sido a marca dessa experiência, ainda assim a gestão não se afastou da influência dos vereadores no bairro.

Contudo, o NICS permitiu à região ocupar um papel destacado no debate governamental sobre as Subprefeituras. Por exemplo, o decreto 41813 que criou os "Governos Locais", em março de 2002, foi baseado na experiência desse Núcleo. Na formulação da lei das Subprefeituras, a AR foi a principal interlocutora com outras regiões e órgãos centrais para debater o projeto. Afora ter redigido a versão inicial da lei das Subprefeituras e da Portaria Intersecretarial que dispôs sobre a estrutura administrativa e de cargos das Subprefeituras. Este papel assumido pela AR deveu-se a dois fatores: a) existência de um modelo de gestão bem avaliado pelo Executivo e que se antecipou ao Governo Local; b) a mudança do Secretário de Implementação das Subprefeituras (SIS), em janeiro de 2002, quando assumiu Jilmar Tatto (PT), exponenciou a ação do administrador regional Tadeu Pais. Assim, para Fernandez, Bógus e Mendes (2006: 125), "isso leva à inferência que, de um lado, o gestor local estava disposto a interferir no processo e, de outro, dispunha de espaço políticopartidário para fazê-lo". A gestão inovadora em relação às demais ARs, somado ao respaldo político da família Tatto, foram singularidades da descentralização na região desde o início. A política e a gestão se encontraram de modo peculiar frente a outros territórios da cidade.

Também coube ao NICS organizar o OP, para o qual foram criadas 12 UPPs (Unidades de Planejamento Participativo), visando aproximar o cidadão dos debates nas localidades. O Núcleo organizava as discussões em torno do chamado "cardápio" formado pelos principais pedidos realizados pela população no ano anterior. Este ordenamento prévio gerava foco para os debates, mas afunilava as deliberações para tais temas e direcionava a agenda das reivindicações populares. A despeito dessas inovações no formato do OP, segundo Cássia Goreti (informação pessoal) ${ }^{56}$, assessora técnica da AR, "o que se vê é que aquele que é historicamente representante, participa de todos os movimentos ...". Tal opinião é similar a de Juan Fernandez (informação pessoal) ${ }^{57}$ ao dizer que

\footnotetext{
Quem participa são sempre os grupos mais mobilizados, mais simpáticos. No governo $\mathrm{X}$ participa X, e no governo Y outros. A participação se dá pela afinidade política dos grupos políticos com o governo e serviu para o OP. [Além disso], havia competição para saber quem levava mais gente [...] para tirar mais representantes e delegados e ai tinha gente que [es]tava lá, não sabia por que, mas tinha que votar em alguém [...]. Ai acontecia assim: chegou o pessoal tal, e a liderança trazia um ônibus cheio de pessoas; então era uma disputa entre partidários, no caso da Capela do Socorro claramente uma disputa entre [Carlos] Gianazzi [liderança emergente na região sul e professor municipal eleito vereador em 2000 que posteriormente divergiu do governo no debate sobre o Plano de Carreira do magistério e saiu do PT] e o grupo dos Tatto.
}

\footnotetext{
${ }^{56}$ Entrevista ao autor em 25/05/2010.

${ }^{57}$ Entrevista ao autor em 21/06/2010.
} 
Se não houve interferência direta dos vereadores na dinâmica do OP, estes influenciaram as deliberações de obras e serviços em bairros eleitoralmente relevantes. Assim, ao invés de se complementar a democracia representativa com mecanismos de democracia participativa, esses últimos foram instrumentalizados pela disputa política local entre grupos petistas. Mesmo com essa competição entre vereadores, não houve ruptura administrativa e política na região, sobretudo pelo peso político da família Tatto junto ao Executivo. O administrador regional, Tadeu Pais, e boa parte de sua equipe de Coordenadores foram mantidos. As indicações realizadas pelos vereadores Edivaldo Estima (filiado ao PPS em 2003) para Assessoria do Gabinete do Subprefeito, de Antônio Goulart (PMDB) para a Supervisora de Assistência Social e de Milton Leite (PMDB) na fiscalização urbana não alteraram a hegemonia política. A partilha do poder continuou dirigida pelo PT e comandada pela família Tatto. A seção seguinte discute a implantação da Subprefeitura em 2003/ 2004.

\subsection{A SUBPREFEITURA: A MESMA DIREÇÃO POLÍTICA, NOVOS PROBLEMAS}

Para Tadeu Pais (informação pessoal) ${ }^{58}$, desde 1988, com a nova ordem constitucional, os governos necessitam de apoio no legislativo para aprovar seus projetos. Porém, a política de alianças construída em São Paulo, com a lógica da vereança adotada para a gestão das Subprefeituras, foi uma causa primordial para a descentralização política e administrativa não ter se enraizado. Embora, na região, a prioridade que o Executivo conferiu para ampliar sua coalizão de apoio deve ser compreendida à luz da experiência local. Como na Capela a organização da Subprefeitura iniciou em 2001, se criaram parâmetros para avaliar o que ocorria no restante da cidade. Por exemplo, segundo Loide Parlato (informação pessoal) ${ }^{59}$, Coordenadora de Planejamento e Desenvolvimento Urbano, no fórum setorial da área, a visão de cada região "ter a sua cara não era levada por todos. [...] Eu levava a cara da Capela com a questão do meio ambiente, dos mananciais [...] A Capela tinha certo avanço no que seria uma Subprefeitura e não mais uma AR.” Esta singularidade regional se identifica na missão do governo local, definida no Planejamento Estratégico (abril/2002): “Construir a Capela do Socorro ambientalmente saudável através do desenvolvimento sustentável e solidário, estimulando e contribuindo para a participação da população e o exercício da cidadania". Esta "proposta central" se desdobrou em cinco objetivos: preservação dos recursos naturais, inclusão social com base nas vocações regionais, gerenciar ações intersetoriais, participação social transparente e democrática e desenvolver novas formas de gestão pública.

\footnotetext{
${ }^{58}$ Entrevista ao autor em 22/04/2010.

${ }^{59}$ Entrevista ao autor em 05/07/2010.
} 
A construção desse marco lógico parece ter sido um diferencial da região na descentralização municipal. Mas para o Governo Local da Capela do Socorro (2002) já se vislumbravam problemas para levar adiante as Subprefeituras: a não indicação e/ou a falta de regularidade na participação de representantes das Secretarias no NICS; dificuldade para as Secretarias disponibilizarem aos representantes locais informações locais e, sobretudo, a indefinição sobre serviços e recursos financeiros e humanos a serem descentralizados. Como o NICS era informal, a resistência das Secretarias foi pequena, mas a formalização do Governo Local direcionado à construção da Subprefeitura ampliou o temor da perda de poder.

Ainda assim, a continuidade política no comando da região e as características locais do modelo de gestão influenciaram a organização da Subprefeitura. Desde o início do governo, o administrador regional assumiu a tarefa de ser o articulador político, apoiado em sua assessoria técnica, junto às Secretarias, associações locais e universidades para promover o NICS e a descentralização. Os serviços urbanos e de administração da AR foram delegados a Alfredo Alves, Chefe de Gabinete. Enquanto um se dedicava a construir a futura Subprefeitura, o outro respondia pelo cotidiano da AR e pela sua gestão. Tal divisão de atribuições, contudo, não foi isenta de problemas e resultou em uma divisão política que veio à tona em 2004 quando Alfredo Alves se candidatou e foi eleito vereador pelo PT. Segundo Juan Fernandez (informação pessoal) ${ }^{60}$, como o Chefe de Gabinete mantinha contato com a população através de assessores que atuavam nos bairros e, além de conhecerem a máquina administrativa, eram seus cabos eleitorais. Portanto, o modelo de gestão conviveu com a política tradicional de prestar serviços à população com pretensões eleitorais futuras.

Porém, mesmo mantendo o núcleo diretivo do NICS (até março/2002) no "Governo Local" (até agosto/2002), a formalização legal das Subprefeituras teve efeitos políticos na região. A necessidade de estruturar administrativamente a Subprefeitura requeria a indicação dos Coordenadores de área e esta escolha gerou um problema: quem era do Governo Local seria coordenador? Como acomodar 20 representantes de Secretarias junto ao NICS em sete Coordenadorias? Como isso não ocorreu, restou aos preteridos serem Supervisores subordinados a chefias que também eram participantes do NICS. Alterou-se a estrutura informal horizontal para uma organização hierárquica formal e, a despeito do discurso da gestão participativa, o cotidiano institucional impôs relações mais verticais entre as áreas.

Na Coordenadoria de Assistência e Desenvolvimento Social (CASD), com suas seis áreas (habitação, trabalho, cultura, esportes, abastecimento, habitação e assistência), a

\footnotetext{
${ }^{60}$ Entrevista ao autor em 21/06/2010.
} 
construção dos acordos políticos foi complexa. Houve problemas, pois foi distinto o tempo de aceitação dos seus Supervisores pelas Secretarias, ademais da necessidade da anuência do Subprefeito para atender o PT local e os vereadores. Tal situação, somada às carências administrativas dos setores, influenciou para que a descentralização das políticas sociais fosse desencontrada. Conforme relata Jussara Vidal (informação pessoal) ${ }^{61}$, Coordenadora da CASD em 2004: na área de esportes só havia o Supervisor, na habitação não havia ninguém e na cultura ela acumulava a função. Acresça-se ainda que a Supervisão de Assistência Social era "um mundo à parte e completamente independente, foi uma mudança postiça. [...] Só mudou fisicamente". Este setor se relacionava diretamente com a SMAS e sem mediação da CASD. Na área do trabalho, como o Executivo não criou uma supervisão específica, a SMTDS continuou a atuar na região com um representante local subordinado ao Secretário. Some-se a isso a disputa em torno dos programas sociais entre esse órgão e a SMAS. Também a Supervisão de Esportes, vinculada ao PCdoB desde o período do NICS, se relacionava de forma direta com o Subprefeito para tratar das demandas de times de futebol. A importância política dessa área na região pode ser avaliada pelo fato de Alceu Tatto ser presidente do Barcelona, clube que em 2004 participou da série B-2 do campeonato paulista e jogava no Capelão, um estádio construído com apoio da Subprefeitura. Para a coordenadora da CASD, prevaleceu a informalidade, inexistiam vínculos entre as áreas e faltavam diretrizes de integração, mesmo porque, no nível central, as pastas continuavam atuando setorialmente e sem descentralizar seus orçamentos. Estes foram alguns dos fatores que influíram na descentralização errática dessa Coordenadoria.

Na Coordenadoria de Educação, o responsável no NICS, Jorge Ribeiro, era vinculado ao vereador Carlos Gianazzi (PT) e, em 2003, foi substituído por uma indicada do vereador Arselino Tatto (PT). Tal situação influiu no isolamento dessa política, visto ter sido a única que passou a ter em seu comando uma pessoa que não participou do NICS e do Governo Local. Seja por ter respaldo político a lhe conferir mais autoridade, pelo maior orçamento ou diante do pouco convívio com a experiência prévia de gestão intersetorial, a educação atuou de forma pouco integrada com as demais áreas. A área receava, assim como a Supervisão de Assistência Social, que suas estruturas, além de perderem sua autonomia administrativa e identidade organizacional, teriam verbas utilizadas para apoiar a implantação das demais Coordenadorias, em face da precariedade de recursos locais. Conforme Jorge Ribeiro (informação pessoal) $^{62}$, como a Coordenação de Administração e Finanças (CAF) local se

\footnotetext{
${ }^{61}$ Entrevista ao autor em 18/08/2010.

${ }^{62}$ Entrevista ao autor em 23/06/2010.
} 
valeu da estrutura administrativa do Núcleo de Apoio Educacional (NAE) houve conflitos com a área.

Além disso, os funcionários do NAE na Subprefeitura continuaram atendendo apenas a Educação, pois as exigências administrativas nas demandas de vagas e na gestão escolar não coincidiam com o tempo para implantar as políticas de recursos humanos e licitações na CAF. Com o temor de, por exemplo, compartilhar recursos para reformas de escola a serem executadas pela Coordenadoria de Projetos e Obras Novas, a Educação buscava manter sua autonomia. Como a CAF era insuficiente em tamanho e capacidade técnica para responder às demandas setoriais, desatar os feudos administrativos nas Coordenadorias também influenciou as dinâmicas setoriais e o caráter errático da descentralização local. Para todos os entrevistados, situações como essa expressaram o recuo da descentralização, se comparada com a experiência do NICS como um período positivo de ação intersetorial. Para Juan Fernandez (informação pessoal) ${ }^{63}$ trata-se de dois modelos diferentes de gestão, pois o Núcleo

[...] se esvaziou já que os responsáveis eram [os coordenadores] e não mais aquele coletivo de vinte, trinta pessoas com reunião semanal. $\mathrm{O}$ fórum foi abandonado e a gestão intersetorial tentou se manter com os coordenadores que tiveram dificuldades, [pois] foram absorvidos na implantação da Subprefeitura e se perderam nas tarefas administrativas [...]. Perderam a motivação da integração em favor da organização setorial que era prioritária inicialmente. [...]O NICS não [es]tava na burocracia e foi um erro ter esvaziado o que tinha de interessante com todos os presentes. Por exemplo, como a Secretaria de Habitação que tinha um assessor no NICS continuaria a participar? Ah, o cara deveria se inserir na Coordenadoria de Planejamento e Desenvolvimento Urbano e ai setorializou a política e perdeu integração.

Para o grupo gestor local, conforme Fernandez, Bógus e Mendes (2006), o NICS era "nostálgico" em face de suas ações intersetoriais, inclusive apoiadas por uma Divisão de Projetos Integrados. Contudo, quando o Plano de Ação do Governo Local (março de 2002) aprovou uma Coordenadoria intersetorial para tratar dos Programas de Inclusão e Participação Social houve, conforme Silva et alii (2006: 111), dificuldades organizativas, visto que

\footnotetext{
A descentralização por meio das Subprefeituras, algo extremamente desejado, elaborado e aprovado em lei, trouxe em seu bojo a necessidade de organização e a dificuldade de alocação de recursos materiais, de funcionários e de procedimentos internos para a organização da estrutura que estava a ser construída localmente. Isso foi agravado por questões específicas dos serviços que foram descentralizados das secretarias municipais e que, pouco a pouco, foram sendo transferidos para as Subprefeituras.

[...] a prioridade do grupo de coordenadores, [...] passou a ser a organização das Coordenadorias e o cumprimento de suas responsabilidades específicas.
}

Quando a Subprefeitura se formalizou legalmente, as demandas administrativas e as pressões políticas para a nomeação de cargos inseriram uma nova dinâmica na gestão local.

\footnotetext{
${ }^{63}$ Entrevista ao autor em 21/06/2010.
} 
Os Coordenadores que assumem têm que controlar a política setorial, que antes dependia da decisão dos Secretários; precisam definir como será organizada a área, antes eles se subordinavam funcionalmente à Secretaria. Também foi necessário compor com o PT e outros partidos a indicação dos cargos, entrando no jogo a partilha do poder e a forma de ocupação de espaços. Além disso, com a criação das Subprefeituras, necessidades orçamentárias e de recursos para executar políticas se tornaram elementos novos na relação do "governo central" com os territórios. Este conjunto de fatores também influenciou o desenho da descentralização na região, já que, segundo Regina Mara (informação pessoal) ${ }^{64}$, assessora do Subprefeito,

[...] entrou o poder, a questão do orçamento e da liberação de verba, complicou muito [...] porque, no início, a gente ficava no campo do debate [...] e não havia o peso da decisão formal que foi dado pela lei. [...] Essa perspectiva de estarmos construindo juntos quebrou na hora em que a lei foi efetivada [...] porque ai o jogo político, o jogo do poder, eles ganharam.

Outra dificuldade para implantar a Subprefeitura, segundo os entrevistados, foi o repasse de atividades e de pessoal sem a contrapartida de orçamento. A relação com as Secretarias passou a ser formal em termos administrativos e suas decisões afetaram as ações locais. Com atribuições e estruturas descentralizadas, mas com o poder orçamentário limitado do Subprefeito, surgiram problemas políticos e gerenciais para implantar as políticas públicas de forma intersetorial, conforme proposto no NICS. Nessa situação, áreas com maiores orçamentos, como Educação, ampliaram sua atuação autônoma, outras, como Saúde, se valiam de relações pessoais com o Secretário para aprovar suas ações. Como as dinâmicas organizacionais, políticas e pessoais de cada Secretaria com as Coordenadorias foram distintas, se criaram processos específicos que fortaleceram intervenções fragmentadas no território. Havia ainda a subordinação formal dos Coordenadores ao Subprefeito, mas dependentes das diretrizes da Secretaria setorial detentora do orçamento. Tal situação exigia negociações e gerava conflitos decisórios entre o "poder formal" vs. o "poder orçamentário". Para Fernandez, Bógus e Mendes (2006: 120-121) tais impasses foram motivados pela

[...] distinção entre a gestão local e a gestão da cidade, bem como a incidência disso na interlocução da Subprefeitura da Capela do Socorro com a administração municipal. O que parece claro é que a tensão que se cria com esse processo de descentralização foi sentida de forma mais intensa na região da Capela do Socorro por conta do investimento que ali havia sido feito na gestão local [...].

Com a perda do referencial de política integrada, e sem orçamento descentralizado, a região se afastou das discussões governamentais em janeiro de 2003. Para a direção local, as Subprefeituras adotaram um rumo conservador ao priorizarem a política de alianças e a

\footnotetext{
${ }^{64}$ Entrevista ao autor em 12/07/2010.
} 
concentração de poder decisório nas Secretarias. Para Tadeu Pais (informação pessoal) ${ }^{65}$, tais questões representaram a derrota política da descentralização no Executivo e foram as causas chave que limitaram o projeto, como será visto a seguir. A rigor, a Subprefeitura reagiu ao rearranjo interno de poder no Executivo que buscou reduzir o peso político do Secretário Jilmar Tatto, conforme discutido no capítulo dois. O isolamento político local foi a resposta ao novo Secretário das Subprefeituras, Antônio Donato, ex-assessor do Gabinete da Prefeita e vinculado ao grupo do Secretário de Governo, Rui Falcão. Com essa mudança, a lógica da vereança se impôs na descentralização, coordenada pela Secretaria das Subprefeituras e apoiada nas negociações da Secretaria de Governo no parlamento. Diante dessa perda de poder político dos Tatto, o núcleo de governo concordou em não interferir na gestão local, o que exponenciou ainda mais sua autonomia em relação às Secretarias. No entanto, o Subprefeito perdeu o respaldo que tinha no Executivo, afora ampliar a oposição de Secretarias, como a SMAS e Cultura, contrárias à influência dos Tatto no governo e na região. Esta foi outra causa política que contribuiu para o caráter errático da descentralização local.

\subsection{A DESCENTRALIZAÇÃO NO TERRITÓRIO E A DISPUTA DE PODER NO GOVERNO MUNICIPAL}

Para os entrevistados, a descentralização era um eixo da reorganização do Executivo, a ser complementada com a reforma administrativa das Secretarias. O modelo ficou incompleto, pois o secretário da SIS, Jilmar Tatto, não conseguiu aprovar ambos os projetos no governo. Isto acarretou a perda do "ímpeto descentralizador" e preservou o poder decisório das Secretarias. Um exemplo, conforme Loide Parlato (informação pessoal) ${ }^{66}$, era a demanda local por um parque, que não se viabilizou, pois a Secretaria do Verde e do Meio Ambiente tinha outras prioridades e o comando sobre a verba. Para Regina Mara (informação pessoal) ${ }^{67}$,

[...] acontece que quando se concretiza a lei, com quem fica o recurso: é o secretário quem vai liberar o orçamento? [...] A pessoa que foi nomeada regionalmente não tinha liberdade de investir seus recursos [...] porque o grande problema que a gente viveu é [...] que você tem um secretário municipal, ele tem poder, ele tem funções, simplificando: ele tem que elaborar políticas públicas para determinado setor. [...][Mas] com quem fica o dinheiro? [...] não houve descentralização de recursos, só os minguadinhos. Concretamente, o Subprefeito, ele ficou não ficou com recursos de todas as sete Coordenadorias representando todas as políticas públicas municipais.

De forma similar, houve problemas para a Subprefeitura intervir em questões como áreas de risco, que envolvia as pastas de Habitação e Assistência Social. Com relação à primeira, as prioridades do Secretário não eram as mesmas do Subprefeito. Este desejava um

\footnotetext{
${ }^{65}$ Entrevista ao autor em 22/04/2010.

${ }^{66}$ Entrevista ao autor em 05/07/2010.

${ }^{67}$ Entrevista ao autor em 12/07/2010.
} 
projeto habitacional para a região, para o que se requeria a descentralização do orçamento. Também na elaboração do Plano Diretor Regional, os Coordenadores nem sempre concordavam com as diretrizes das Secretarias para a região, mas não dispunham de recursos financeiros. Assim, mesmo que a lei 13399 tenha igualado Subprefeitos e Secretários, na prática os últimos continuaram a deter importante do poder decisório, sobretudo recursos financeiros. Na Capela do Socorro, a resistência das Secretarias em descentralizar se ampliou após o Secretário Jilmar Tatto solicitar que o Subprefeito e sua assessoria fossem debater a descentralização com tais órgãos. Além do receio da perda de poder pelas Secretarias, havia o temor de aumentar ainda mais a influência dos Tatto no Executivo e na região, caso se aceitasse a tese da descentralização de orçamento para a Subprefeitura. Por exemplo, a disputa entre a Secretária da Assistência Social, Aldaíza Sposati, e Jilmar Tatto, refletia a posição do então Secretário da SIS de não criar, nas Subprefeituras, uma Coordenação para aquela política. Houve a ruptura da SMAS com o Subprefeito por este integrar o grupo politico dos Tatto, e a Secretaria passou a se relacionar diretamente com a Supervisora local indicada pelo vereador Antônio Goulart (PMDB). Estas disputas no PT também influenciaram o caráter errático da descentralização. A esse respeito Westphal e Dias (2006: 132), enfatizam que

$\mathrm{O}$ aludido projeto de gestão descentralizada e integrada [...] que foi concebido como uma reforma política no âmbito da prefeitura municipal [...] não conseguiu plenamente seu objetivo de reorientar o modo de gestão e otimizar recursos.

[...] Questões ideológicas, de formação e relações tradicionais de poder, fazem parte dos processos resistentes a mudanças, especialmente quando analisados a partir das ocorrências no centro do poder.

Para os entrevistados, as Subprefeituras retrocederam com a ação conservadora do Executivo em duas questões. Primeiramente, não houve a reforma do Estado local para reduzir o tamanho e atribuições das Secretarias em favor das Subprefeituras e redistribuir poder político no governo. Em segundo lugar, a prioridade que a governabilidade assumiu, a despeito de sua importância para aprovar os projetos no parlamento. O Executivo, para Tadeu Dias (informação pessoal) ${ }^{68}$, fragilizou politicamente a descentralização com a lógica da vereança nos territórios. Para o Subprefeito, era um equívoco os vereadores atuarem como "despachantes" do Executivo na Câmara e ocuparem postos de gestão sem conhecer as políticas públicas. $\mathrm{Na}$ região, a hegemonia da família Tatto se manteve, mesmo com a participação de grupos internos do PT e de vereadores de outros partidos, e a gestão não foi por isso menos fisiológica. Conforme essa avaliação, o "loteamento de cargos" fragilizou as Subprefeituras como interlocutoras das etapas seguintes da descentralização. Sobretudo, não

\footnotetext{
${ }^{68}$ Entrevista ao autor em 22/04/2010.
} 
implantar os Conselhos de Representantes foi, para Juan Fernandez (informação pessoal) ${ }^{69}$ mais um recuo do governo em direção à lógica da vereança, pois

Votar o Conselho de Representantes era por o dedo na ferida do lado de cá das Subprefeituras e não fazê-lo já mostrava que, poxa, vai até certo ponto, afinal de contas esse governo tem que votar coisas na Câmara e não vai correr riscos por causa disso. [...] O que tá colocado lá, de fato, é uma descentralização não só administrativa, mas de poder, e o Conselho de Representantes era explícito e direto nisso [...].

Para o grupo gestor da Capela, a descentralização acabou sendo também um recurso político para construir e ampliar a política de alianças, cuja contrariedade de um gestor local é transcrita em Fernandez, Bógus e Mendes (2006: 127): “descentralizar e dar poder para os 70\% que não acreditam nisso? Vou descentralizar para isso daí?" A divergência com a política fisiológica do governo para as Subprefeituras também ocorreu internamente ao PT na região e acarretou a ruptura do Subprefeito com a família Tatto. Com a criação das Subprefeituras, esse grupo político, a exemplo do que fizeram os criticados vereadores chamados de clientelistas pelos petistas, queriam indicar os cargos diretivos e de coordenação. Não houve acordo, pois o Subprefeito defendia a continuidade do NICS com o argumento de que cargos técnicos não entrariam na barganha e na partilha interna de poder. Sobretudo, com os técnicos das Secretarias que permaneceram Coordenadores em áreas como planejamento urbano, assistência, obras e saúde. Esta última foi emblemática, pois era professora da Unisa (Universidade de Santo Amaro), considerada pela família Tatto um ator político vinculado ao PSDB local. O Subprefeito manteve os cargos diretivos, mas franqueou aos Tatto a indicação da Coordenação de Educação e outras funções, o que lhes permitia "monitorar" toda Subprefeitura. Para a família Tatto não interessava romper com Tadeu Pais, pois mudar as políticas públicas poderia gerar problemas na região e no governo, visto que, em 2003, já se vislumbrava a eleição municipal de 2004. Mas, nas Supervisões, o controle do Subprefeito era menor, conforme Jussara Vidal (informação pessoal) ${ }^{70}$, coordenadora da CASD:

\begin{abstract}
Eu sei que o Tadeu deve ter sofrido muito para ter indicado alguém de uma área técnica para coordenar [...] porque tinha muita disputa. [...] eu não tinha decisão sobre o cargo de supervisor, de dizer, olha: esse [...] não tá adequado, não existia essa possibilidade. Já estava lá. [...] No âmbito da Coordenadoria não tinha poder de decisão nenhuma. Cada uma tinha as suas, por exemplo, a Secretaria de Esportes era do PCdoB; o supervisor era do PCdoB.
\end{abstract}

Segundo Juan Fernandez (informação pessoal) ${ }^{71}$, "os vereadores eram donos das Subprefeituras". Para esse entrevistado, o vereador Arselino Tatto (PT) aceitou a ocupação dos cargos técnicos da Subprefeitura até o momento em que a lei 13399 criou a possibilidade

\footnotetext{
${ }^{69}$ Entrevista ao autor em 21/06/2010.

${ }^{70}$ Entrevista ao autor em 18/08/2010.

${ }^{71}$ Entrevista ao autor em 21/06//2010.
} 
de nomeá-los diretamente na região; assunto que "falam o dia inteiro. E nesse período [...] a interferência era maior para as indicações", o que impactava na cisão entre o "mundo da gestão" e o "mundo da política". Para Jane Armond (informação pessoal) ${ }^{72}$, Coordenadora de Saúde, havia pessoas que chegavam "encargadas", "sou o novo" [referindo-se ao cargo para o qual a pessoa se apresentava para ocupar após sua indicação] e o Subprefeito tinha que ceder, mesmo sendo contrário, diante da primazia da lógica da vereança. Conforme Loide Parlato (informação pessoal) ${ }^{73}$, no desenvolvimento urbano, se impuseram as indicações do vereador Milton Leite (PMDB) na fiscalização de uso e ocupação do solo, onde prevalece o contato direto com a população na regularização fundiária e de loteamentos. A fala de Jorge Ribeiro (informação pessoal) ${ }^{74}$ ilustra a relação entre a lógica da vereança na região e a formação da coalizão de apoio na Câmara ao dizer que a "influência do vereador não tem jeito, senão não governa. E ai o aprendizado do governo Erundina que não conseguia governar com a oposição na Câmara. Ainda houve muita influência de vereadores nas decisões de políticas [...]”.

Portanto, a política de alianças do Executivo, e as ações da família Tatto para garantir a hegemonia local, em nada diferiram do fisiologismo na distribuição de cargos que o PT criticava como prática malufista para lotear as antigas ARs. Ainda assim, a despeito da divisão de áreas internas de influência e da partilha de poder, a Subprefeitura buscou, sem muito êxito, integrar as políticas públicas, como será discutido na próxima seção.

\subsection{OS LIMITES E IMPASSES NA INTERSETORIALIDADE DAS POLÍTICAS}

A gestão integrada de políticas nos territórios não foi bem sucedida. A ausência da reforma administrativa no nível central manteve as ações fragmentadas e os feudos políticos dos vereadores nas regiões também influíram nessa falta de integração. Some-se a isso que a organização das Coordenadorias prevaleceu sobre as ações intersetoriais que o NICS promovia. A lei das Subprefeituras, ao suprimir a área de gestão integrada que existia na região, também influiu para reduzir a intersetorialidade. Houve ainda timings distintos de cada setor para descentralizar atividades, os responsáveis locais e o orçamento. Agreguem-se ainda as distintas compreensões administrativas e o fato de a experiência do NICS não ter sido vivenciada por todas as chefias que assumiram na Subprefeitura. Por fim, o fórum de coordenadores não conseguiu integrar as áreas, pois, segundo a coordenadora da CASD, suas reuniões tinham um caráter mais informativo e menos de formulação.

\footnotetext{
${ }^{72}$ Entrevista ao autor em 01/07/2010.

${ }^{73}$ Entrevista ao autor em 05/07/2010.

${ }^{74}$ Entrevista ao autor em 23/06/2010.
} 
Contudo, a região implantou um programa chamado "Capela Saudável”, iniciativa pioneira no âmbito municipal e inserido no movimento por Cidades Saudáveis da Organização Mundial da Saúde. A diretriz central era superar o paradigma da atenção médica curativa e atuar de forma integrada sobre os fatores que incidem sobre a saúde. Para o grupo gestor local tal pressuposto era coerente com a descentralização pautada pela democratização política e o controle social. Em face da existência do NICS, o projeto "Capela Saudável” era visto como um meio de aprimorar a gestão intersetorial e participativa de políticas. Assim, Conselhos Gestores de Saúde, Conselhos de Escolas, Fórum de Delegados do OP e Núcleos de Defesa Civil, dentre outros, poderiam se integrar em torno da promoção à saúde.

O projeto teve início em março de 2003 constituindo uma Comissão Técnica formada pelas Coordenadorias e o Gabinete do Subprefeito como fórum responsável pela ação piloto em duas UPPs. Os polos estruturadores foram quatro unidades de saúde locais, escolhidas como centros irradiadores por já terem conselhos gestores com representantes da sociedade, e foram a base para organizar os Comitês Locais coordenados pelo Comitê Geral do Projeto. Esta estrutura tinha como objetivo transformar o projeto em um eixo estruturante da gestão regional. No entanto, essa intenção se deparou com sucessivas mudanças na composição da equipe técnica que dificultaram manter a continuidade na construção de políticas. Como não eram os Coordenadores setoriais que participavam, esse fórum se ressentia de autoridade formal, o que gerou desligamentos de representantes, inclusive da Saúde. Outras áreas importantes como a Educação, cuja coordenadora não participara do NICS, tiveram uma inserção inconstante. A participação se reduziu de modo que, no ano de 2004, o projeto passou a ser monitorado apenas pelo Gabinete do Subprefeito e integrantes da Coordenadoria de Saúde, ao invés dos sete representantes originais de todas as Coordenadorias (LICO \& FERNANDEZ, 2006). Também houve baixa adesão das Secretarias municipais por avaliarem que o sucesso do empreendimento fortaleceria a hegemonia dos Tatto na região e resultaria em pressões por mais verbas descentralizadas, contrariamente aos interesses desses órgãos.

Ainda assim, se implantaram práticas de gestão participativa nas regiões piloto, como oficinas de planejamento, visando mobilizar as comunidades para identificar problemas e elaborar propostas para melhorar a qualidade de vida. Buscou-se ampliar as iniciativas intersetoriais em torno dos eixos: a) "saneamento ambiental" (capacitação de agentes ambientais, Central de Triagem, Reciclagem e Postos de Entrega Voluntária para coleta de seletiva de lixo e Comitê Regional de Combate à Dengue) e; b) “criação de espaços saudáveis" (Brincando na Praça, Terapia Comunitária e o Sábado Saudável que reunia saúde, esportes, cultura e educação). Mas, segundo Lico e Fernandez (2006: 71), houve 
A dificuldade de criação e fortalecimento de vínculos entre a comissão e entre os participantes [que] deveu-se, principalmente, às características de alguns atores, lideranças políticas da região. Muitos participavam do comitê com a intenção de obter subsídios da Subprefeitura para realizar seu projeto pessoal ou da entidade que representavam. Em muitas reuniões, as discussões foram marcadas por conflitos de interesse expressando divergências e competições antigas existentes.

Esta situação também contribuiu para a perda do ímpeto participativo do projeto. Conforme Juan Fernandez (informação pessoal) ${ }^{75}$, havia reuniões de avaliação com representantes da Organização Pan-Americana de Saúde (sponsor do projeto), os indicados pelas Coordenadorias e os quatro Comitês Intersetoriais Locais. O suporte executivo era das Coordenadorias que, pela descontinuidade de seus representantes, não cumpriram tal tarefa e desgastaram a relação com a população nos comitês locais. O projeto teve alcance limitado na gestão do território, pois, segundo Westphal e Dias (2006): a) deveria ser estruturante das ações da Subprefeitura e acabou sendo responsabilidade de uma comissão técnica, que avançou na interlocução com a população através dos comitês locais, mas não conseguiu integrar o trabalho com as Coordenadorias chave de saúde, educação, planejamento urbano e assistência social. As Coordenadorias mantiveram seus planos setoriais e desarticulados das experiências piloto; b) as demandas da população, através dos comitês locais, não tinham legitimidade junto ao grupo gestor da Subprefeitura e não foram priorizadas, o que resultou na retração da participação nas regiões e; c) a implantação administrativa da Subprefeitura simultaneamente à organização do projeto. Assim, para Jussara Vidal (informação pessoal) ${ }^{76}$,

[...] o que a gente desenvolveu no âmbito da Coordenadoria não foi avaliado no âmbito do Capela Saudável, foi uma experiência isolada ainda assim. [...] Para mim [roteiros turísticos regionais para portadores de deficiência] está exatamente dentro de uma ideia de cidade saudável de ter acesso a bens culturais [...] de vida comunitária para pessoas que estão reclusas. Agora isso não foi pensado no âmbito do Capela Saudável [...] e sim daquilo que a gente entende como educação não formal.

A relação entre a Subprefeitura e as Secretarias também limitou a ação intersetorial no território. Para Loide Parlato (informação pessoal) ${ }^{77}$, muitas vezes a região definia prioridades, como a construção de postos de saúde, que não eram consideradas pela pasta central detentora do orçamento. Nesses casos, se apresentava a demanda via OP para entrar na previsão orçamentária da área, o que também evidenciava a instrumentalização desse processo participativo para atender certos públicos. Em outro exemplo, o grupo gestor da Subprefeitura aprovou a remoção de pessoas de uma área de risco contrariamente aos interesses da Secretaria de Habitação. A solução foi utilizar uma área da Secretaria de

\footnotetext{
${ }^{75}$ Entrevista ao autor em 21/06/2010.

${ }^{76}$ Entrevista ao autor em 18/08/2010.

${ }^{77}$ Entrevista ao autor em 05/07/2010.
} 
Esportes (uma "sobra" de um campo de futebol) para implantar a decisão local, mas sem apoio da Secretaria. A implantação dos CEUs (Centros de Educação Unificados) também gerou problemas na gestão intersetorial, pois no Conselho Gestor a educação e a cultura privilegiavam as suas demandas. Ademais, os Centros tinham seu orçamento subordinado à Secretaria da Educação e não respondiam formalmente ao Subprefeito, o que contribuiu para aumentar sua autonomia. Em áreas como a CASD, as dificuldades de intersetorialidade foram maiores, pois, excetuada a política de assistência, os demais cinco setores tinham poucos recursos financeiros. Nessa Coordenadoria, o maior paradoxo era a área cultural, pois os CEUs respondiam à pasta da Educação que, por dispor de orçamento, definia a grade das atividades de forma centralizada. Para Jussara Vidal (informação pessoal) ${ }^{78}$,

\begin{abstract}
[...] a CASD foi criada, mas não foi incorporada de fato. Quando você muda uma estrutura você tem que criar novos mecanismos para estabelecer novas relações. [...] Faltou um respaldo, uma linha, uma diretriz. [...] Então cada um fez o que achava melhor ou não fez, [porque] não era cobrada. [...]. Não dá para fundamentar uma politica social na boa intenção e numa colcha de retalhos onde cada uma faz o que quer.
\end{abstract}

A integração de políticas não logrou êxito e teve alcance limitado na gestão da Subprefeitura, assim com a participação popular, que se discute a seguir,

\title{
4.6 A PARTICIPAÇÃO POPULAR: OS AVANÇOS E OS ENTRAVES EXISTENTES
}

Além da peculiar organização em doze UPPs (Unidades de Planejamento Participativo), a região organizou, em 2001, o Conselho Regional do Orçamento Participativo (CROP-CS), composto pela direção da AR e os delegados que a população elegia nas assembleias. Até março de 2002, tais inovações territoriais buscavam ampliar a interlocução com os movimentos sociais. Após a criação das Subprefeituras, o ciclo do OP/2003 modificou as plenárias temáticas, que passaram a ser organizadas em cinco assembleias, conforme as áreas de atuação das Coordenadorias: Saúde, Educação, Infraestrutura e Manutenção, Planejamento e Desenvolvimento Urbano e Assistência Social. Este processo, que parecia um avanço ao se assentar nas estruturas descentralizadas, foi um retrocesso, pois gerou uma "paroquialização" e setorialização da política. Limitou-se a discussão regional a áreas previamente definidas, sem que a sociedade pudesse incidir sobre temas estruturais da cidade ou que afetassem mais de uma região, o que dificultou a construção de políticas integradas. Além do mais, nos debates do OP, segundo Regina Mara (informação pessoal) ${ }^{79}$,

\footnotetext{
${ }^{78}$ Entrevista ao autor em 18/08/2010.

${ }^{79}$ Entrevista ao autor em 12/07/2010.
} 
[...] a decisão não é tão aberta para uso do recurso público. Você vai, fala, olha, a gente tem recurso para uma unidade de saúde. [...] você tá numa decisão [...] você tá numa realidade local de déficit de atendimento, ou de cruzamento de população $v s$. possibilidades de UBS ou o que for. Então, não é o líder comunitário que vai ficar lá insistentemente dizendo "lá no meu bairro ocorre $x "$

A Subprefeitura, ao organizar o "cardápio" das demandas pela disponibilidade de verba das Coordenadorias, induzia o debate em torno dessas definições prévias. Assim, para Jussara Vidal (informação pessoal) ${ }^{80}$, o OP não alimentou "grandes mudanças, [pois] são as mesmas pessoas e as demandas se adequam ao que já está pensado de fazer regionalmente pelas Secretarias". Por exemplo, a previsão de se construir campos de futebol em função da relação da família Tatto com os times locais. A organização dos CEUs, ao se tornar a prioridade da Secretaria da Educação, também reduziu os recursos disponibilizados da área para o OP em 2003/2004, como enfatizado no capítulo dois. Este equipamento foi implantado pelo Executivo visando corrigir a "distorção" que setores locais mais mobilizados poderiam acarretar no direcionamento das verbas, em prejuízo da região como um todo. Mas tais ações contrariavam o discurso da organização da sociedade local para disputar recursos, e fortaleciam políticas centralizadas que não se subordinavam ao Subprefeito.

Em relação ao controle social das deliberações aprovadas nas assembleias do OP, duas críticas foram realizadas pelos entrevistados. Para Juan Fernandez (informação pessoal) ${ }^{81}$, apesar de mobilizar a população, entre a decisão coletiva e sua materialização, ninguém verificava se as decisões do OP tinham retorno, pois o controle social era reduzido e difícil de ser avaliado. Para Jorge Ribeiro (informação pessoal) ${ }^{82}$, as prioridades aprovadas não foram efetivadas com a justificativa da falta de recursos, mesmo que demandas menos relevantes fossem implantadas, além de a sociedade não controlar os critérios adotados pelas Secretarias nas suas análises técnicas. As Secretarias buscavam "tecnicamente" manter sua agenda de prioridades políticas ao explicarem suas decisões à sociedade. Ademais, as emendas parlamentares ao orçamento concorriam com o OP para atender o vereador nos territórios. Assim, a democracia participativa era secundarizada pelo Executivo, em favor de sua política de alianças, já que os vereadores dispunham de recursos políticos desiguais em relação à sociedade: voto para aprovar projetos do governo, o que tornava suas demandas prioritárias.

A Capela do Socorro era uma região com grande influência do PT, tanto que nas eleições para prefeito em 2004 a candidata Marta Suplicy venceu nos três distritos em ambos

\footnotetext{
${ }^{80}$ Entrevista ao autor em 18/08/2010.

${ }^{81}$ Entrevista ao autor em 21/06/2010.

${ }^{82}$ Entrevista ao autor em 23/06/2010.
} 
os turnos. Este lastro político talvez tenha contribuído para fortalecer os vínculos dos movimentos sociais com o OP, já que, conforme Loide Parlato (informação pessoal) ${ }^{83}$,

[...] sempre há uma faç̧ão da população que tem mais afinidade com o PT não porque apoiam o PT, mas porque os outros não têm interesse em incentivar a participação. [...] Você só participa se você sabe que sua participação vai ter eco [...] O movimento de moradia, educação e saúde das regiões, a maioria tem grande envolvimento político, mas cuja autonomia era muito dependente do PT no governo. Quando entrou outro partido [o governo Serra em 2005] foi totalmente desfeito.

Ainda que o OP tenha mobilizado as entidades da região, havia um cálculo político do Executivo e da Subprefeitura em estimular esse processo: mais do que atender ao programa de governo de ampliar a democracia participativa se tratava de aproximar o PT dos movimentos populares com vistas a obter apoio político e eleitoral. Na região, isso significava também manter a hegemonia da família Tatto na política local.

Além do OP, a região buscou responder à lacuna do Conselho de Representantes, defendida pelo grupo gestor local para ampliar o controle social e a descentralização do poder legislativo. Amparado no projeto Capela Saudável, e na questão ambiental priorizada no Planejamento Estratégico/2002, foi criado o Conselho Regional de Planejamento e Desenvolvimento Sustentável (CRPDS). Este fórum era integrado pelo poder público e entidades de base local, visando elaborar e monitorar políticas públicas de desenvolvimento sustentável com inclusão social e voltadas a preservar o meio ambiente. Inicialmente, foi organizado o Pró-Conselho, responsável pela eleição dos integrantes que representavam a sociedade no território (15 membros) e em segmentos específicos (15 membros). A escolha ocorreu entre novembro/dezembro de 2003 e mobilizou 3396 pessoas nos território e 79 pessoas nas entidades (número pouco representativo, em face das 15 vagas). Os demais 30 representantes eram indicados pelo poder público (18 em nível municipal, 8 da administração estadual e quatro de órgãos federais). Os 60 conselheiros tomaram posse em fevereiro de 2004 com a tarefa de ampliar a participação social. Contudo, segundo Silva et alii (2006: 97),

Como todo foro participativo, tivemos que lidar com problemas com a população participante que, em função da nossa cultura política, paternalista e clientelista, assumia uma função mais de caráter reivindicatório e não propositivo, solidário e de parceiro da administração.

Apesar da proximidade política das entidades locais com o PT, parece ter havido dificuldades de o partido construir sua hegemonia sobre as mesmas, para o que a crítica da falta de solidariedade com a administração soa mais como um eufemismo. Sob esse enfoque é possível compreender a decepção que os autores acima apresentam. Muitos Coordenadores

\footnotetext{
${ }^{83}$ Entrevista ao autor em 05/07/2010.
} 
não compareciam às reuniões do Conselho, o que gerou dificuldades na interlocução com as entidades e seu esvaziamento junto ao núcleo gestor da Subprefeitura. Mesmo com esses limites, o Pró-Conselho, formado em 2002, foi importante para mobilizar a sociedade, visando elaborar o Plano Diretor Regional. Com a aprovação do Plano Diretor Estratégico da Cidade de São Paulo (lei 13430), as Subprefeituras deveriam elaborar seus planos regionais, o que ocorreu de novembro de 2002 a março de 2003, e definir instrumentos de desenvolvimento urbano local para o período 2006 a 2012. Realizaram-se reuniões com segmentos (comércio, indústria, agricultura etc.) e plenárias com associações de moradores nas UPPs para a eleição de representantes para as oficinas de elaboração do Plano Regional. Segundo os entrevistados, essa foi uma experiência positiva de mobilização intersetorial e participativa, apesar de o Plano não ter sido implantado.

A experiência da Subprefeitura da Capela do Socorro mostra como a continuidade da direção política local não garantiu a implantação da agenda da descentralização. Isto porque o deslocamento de forças no Executivo retirou o apoio político da região junto ao Secretário da SIS e alterou a relação com as Secretarias municipais que deveriam repassar atividades e recursos. A mudança política promovida pelo governo na coordenação política da descentralização alterou a dinâmica da gestão local e ampliou as dificuldades de se implantar a Subprefeitura no debate com os órgãos centrais. O efeito mais visível foi a forma errática como a descentralização ocorreu, sobretudo, com a fragmentação das políticas em áreas chave como a CASD. Se a construção da política de alianças não alterou a hegemonia política local, a disputa interna ao governo intensificou a oposição de grupos petistas concorrentes à família Tatto. A convivência interna dos indicados pelas correntes internas do PT com aqueles oriundos das lideranças políticas tradicionais do PPS e PMDB não foi traumática e serviu para acomodar os interesses desses vereadores. E como a direção política se manteve, não houve disputa pelo controle interno da Subprefeitura. Contudo, com a derrota política de Jilmar Tatto no centro do governo, a região perdeu a proeminência que possuía como protagonista da descentralização. Na Subprefeitura, o núcleo dirigente se opunha à lógica da vereança e a prioridade conferida à barganha de cargos para formar a coalizão de apoio nos territórios. Mas, a descentralização local foi um importante recurso político para a família Tatto ampliar sua hegemonia na região, para o que a política fisiológica de distribuição de cargos similar à prática malufista que existia nas ARs foi central. Como resultado, esta partilha de poder e de cargos na região teve um peso político maior na gestão local do que os processos participativos e de controle social enfatizados pelo discurso petista. 


\section{CONCLUSÃO}

Quando Tocqueville (1977) analisou a descentralização administrativa das comunas americanas no século XVIII destacou seus efeitos políticos, sobretudo sua independência de ação e a dispersão de poder para aproximá-las da população. Estas questões foram incluídas no programa de governo do PT à Prefeitura de São Paulo para as eleições de 2000, embora a política do governo não tenha construído os chamados "núcleos locais de poder". Portanto, nessa conclusão, é importante verificar se as hipóteses de trabalho e as condições causais que incidiram na configuração política e institucional das Subprefeituras são sustentáveis. Em segundo lugar, a partir dos casos estudados, com suas similaridades e diferenças, identificar os elementos que permitam generalizações preliminares aplicáveis às 31 Subprefeituras.

Administrativamente, a descentralização visava delegar atribuições e recursos das Secretarias para a gestão territorial. Com as Subprefeituras, as atividades e serviços, especialmente aqueles mais próximas dos cidadãos nos bairros, deveriam ser executados localmente. Assim, 31 Subprefeituras assumiriam as tarefas até então gerenciadas por 21 Secretarias e órgãos municipais. Para tanto, seria necessário racionalizar a administração das regiões, visando reduzir o custo dessa operação e também para que ela atendesse aos objetivos propostos de melhorar a qualidade dos serviços prestados à sociedade. Do ponto de vista gerencial se compreendia que a maior inovação seria a construção de políticas intersetoriais, para o que se definiu uma estrutura organizacional baseada em coordenadorias temáticas que reunissem áreas com afinidade de atuação. Por fim, a implantação das Subprefeituras deveria ser o primeiro momento de uma reforma administrativa do Estado em nível municipal que possibilitaria reduzir suas estruturas em favor da descentralização de competências.

Contudo, tal política não seguiu essa trajetória virtuosa, pois, com base na análise realizada, constatou-se que a descentralização das políticas setoriais para as regiões não ocorreu de maneira regular e uniforme. A investigação dos casos da Freguesia do Ó e da Capela do Socorro confirmam uma das hipóteses da pesquisa de que a descentralização administrativa foi errática, visto que o seu ritmo, escopo e os interesses dos atores políticos à frente das Secretarias condicionaram o seu formato. A despeito de o governo determinar a descentralização de atividades para os territórios, cada Secretaria teve um comportamento distinto em relação às Subprefeituras, conforme discutido nos dois casos analisados. Esta falta de unidade administrativa da descentralização foi o resultado político do temor das Secretarias de perderem poder para as regiões. Agregue-se ainda o duplo comando ao qual estavam submetidas as Coordenadorias locais, conforme se mostrou no capítulo dois no organograma das Subprefeituras: hierarquicamente submetidas ao Subprefeito, mas funcionalmente 
dependentes da política emanada da Secretaria setorial. Tal desenho, complexo de operar por depender da delimitação de níveis de poder em cada esfera, também respondeu por impasses administrativos sobre o comando das políticas nos locais. Desse modo, o modelo que propunha às Secretarias formularem e monitorarem políticas nas regiões, cabendo a essas a execução, não se organizou e fez com que a descentralização administrativa fosse errática.

Como a reforma administrativa do nível central do governo foi uma tese derrotada, se manteve uma relação conflituosa das Secretarias com as Coordenadorias regionais. O desenho organizacional dos territórios se baseava na unificação de áreas que se mantiveram isoladas no nível central, e não havia unidade de ação "em cima" que respaldasse a atuação intersetorial "em baixo". Este desencontro também foi responsável pelo fracasso em se implantar a intersetorialidade das políticas públicas nas regiões, pois fortaleceu as lógicas particularistas de atuação. Cada Secretaria estabeleceu relações com sua contraparte descentralizada visando reduzir a perda de controle sobre a política. Some-se a isso que a divisão de influência setorial entre vereadores e grupos do PT também contribuiu para essa fragmentação. Presume-se que esse processo tenha se replicado nas 31 Subprefeituras, pois o modelo político e gerencial e as Secretarias eram as mesmas, apesar das diferenças locais, conforme visto nos dois casos analisados. Contudo, efeitos administrativos similares nas regiões investigadas, apesar de condições causais distintas, apoiam a hipótese do caráter errático da descentralização em São Paulo. Esta generalização preliminar poderia ser verificada em outras Subprefeituras para se comparar com a Freguesia do Ó e a Capela do Socorro. Também pode essa hipótese sobre a experiência paulistana servir de referência para outros contextos municipais que implantaram a descentralização da gestão territorial.

Politicamente, pelo discurso petista, a descentralização construiria o "poder local" e a democracia participativa nas regiões. Com as Subprefeituras, reforçadas pelo controle social e participação popular, através do OP e do Conselho de Representantes, as regiões incidiriam no rumo das políticas públicas municipais. Esta concepção, já presente no governo Luiza Erundina, ganhou fôlego durante a campanha eleitoral em 2000 como alternativa ao modelo falido das ARs. As Subprefeituras, apoiadas na fiscalização da sociedade, seriam o antídoto para combater a falta de eficiência e de transparência das antigas regionais. Sobretudo, as Subprefeituras eliminariam o monopólio das ARs pelos vereadores dos bairros e a forma como o governo se valia das mesmas distribuindo sinecuras para construir sua política de alianças. Ao parlamento se destinaria o lugar nobre de debater os grandes temas municipais e às Subprefeituras a gestão local a ser decidida democraticamente com a população. 
A trajetória da ação política do governo caminhou em sentido oposto, pois se mantiveram padrões fisiológicos na relação com os vereadores, similares aos que eram criticados pelo PT como prática malufista de cooptação. Mas, uma vez que a tese das Subprefeituras conquistara amplo apoio social como alternativa moralizadora frente às ARs, o PT passou a trabalhar com o eufemismo do "governo amplo" para reduzir o desgaste público sobre a forma como construía e ampliava a sua base aliada. Contudo, a partilha de poder nos territórios entre os parlamentares petistas e dos demais partidos em nada difere, na forma e em seus resultados, do que Couto (1998) chamou de coalizão fisiológica de governo. Lembrando Dahl (1989), o objetivo do Prefeito é obter a aquiescência estável dos vereadores para suas políticas, o que geralmente se consegue com a máquina de empregos públicos que existe (ou, no caso de São Paulo, a que foi criada com as Subprefeituras). Nesse sentido, as Subprefeituras, eixo programático da candidata Marta Suplicy, se transformaram em recurso político do governo para a barganha com os vereadores, visando ampliar e consolidar sua coalizão de apoio. A análise dos dois casos, apesar das distinções sobre a forma como se deu essa partilha, corrobora uma parte da segunda hipótese de trabalho relativa à lógica da vereança. Com efeito, as Subprefeituras exponenciaram a política historicamente vigente no município de dividir os territórios com os vereadores e demais grupos políticos, pois sua estrutura de cargos e de recursos financeiros era maior que a existente nas ARs.

A outra parte dessa hipótese diz respeito à política do governo de secundarizar os mecanismos de democracia participativa na gestão das Subprefeituras. Esta questão não pode ser desvinculada da prioridade que o Executivo conferiu à política de alianças e aos vereadores para aprovar projetos no parlamento e manter a governabilidade. $\mathrm{O}$ discurso democrático petista, sobretudo a fiscalização do Conselho de Representantes junto aos Subprefeitos e vereadores nos bairros, foi abandonado, em linha com a visão de Dahl (1989) discutida no capítulo 1 sobre o formato dos processos participativos que mais convém ao governo. Nesse sentido, o debate sobre essa instância foi desvinculado daquele dedicado à criação das Subprefeituras, pois o governo temia por em risco a sua política de alianças. Entre fortalecer o controle social e a democracia participativa, ou estreitar os vínculos com os vereadores do PT e os partidos da base aliada, prevaleceu essa última na ação do Executivo. Pelo programa de governo, o que seria a sequência da descentralização, cedeu lugar à divisão de poder com os vereadores em vigor na política municipal desde a gestão Jânio Quadros (1985-1988). Ao mesmo tempo, o OP se manteve por duas razões: a imagem do PT como partido vinculado a formas participativas, considerando as gestões em outras cidades brasileiras, ademais de fazer concessões a setores internos do partido. Porém, e mais 
importante, com o OP o PT buscava hegemonizar os movimentos sociais de bairro, ainda que esses fossem atores políticos secundários na coalizão de governo. Tanto que, nos dois casos analisados, essa instância, por diferentes razões, não teve proeminência na gestão local. Isto ocorreu porque os recursos financeiros do Executivo foram reduzidos e pela importância atribuída às emendas parlamentares em relação às ações aprovadas no OP.

Com base nas entrevistas realizadas, e nas informações da tabela 2.2 do capítulo dois que mostra a participação dos vereadores nas Subprefeituras, tem-se outras evidências que também ajudam a confirmar a segunda hipótese de trabalho. Ainda que os modelos de partilha de poder em cada localidade tenham sido distintos, em face do peso e influência dos atores políticos locais, a forma como as Subprefeituras foram utilizadas para esse fim foi invariável. Da mesma forma, as condições causais que provocaram a ação do governo em favor da divisão de poder com os vereadores são as mesmas para todas as regiões, e derivaram da tese que era necessário se construir uma maioria de apoio parlamentar para aprovar projetos e evitar o isolamento político ocorrido na gestão Erundina. Ao invés do discurso da governabilidade suportada pela democracia participativa prevaleceu o criticado "toma-lá-dacá” da política, considerado pelo discurso petista como fisiológico e malufista.

Em síntese, tomando as duas hipóteses de trabalho e seu cotejamento com a análise dos dois casos, vê-se que o mesmo fenômeno - a implantação das Subprefeituras - teve similaridades e diferenças. A fim de se sugerir uma generalização a ser testada em outras regiões, a Freguesia do Ó pode ser caracterizada como um tipo de partilha de poder que provocou a perda de hegemonia política do PT, mas manteve sua presença na gestão. A luta interna entre os petistas e os malufistas serviu para acentuar o caráter errático da descentralização, somada à oposição das Secretarias ao grupo do novo Subprefeito. Na Capela do Socorro, o padrão de divisão de poder foi a continuidade da hegemonia da família Tatto e a composição política com vereadores de outros partidos, mas em cargos de menor expressão política e sem peso decisório. Contudo, como se tratava de um grupo forte no interior do PT, a sua proeminência na região gerou resistência das Secretarias em repassar atividades para não fortalecê-lo ainda mais, o que incidiu no caráter errático da descentralização. ${ }^{84}$

No governo José Serra (PSDB/2005-2006), as Subprefeituras mudaram sua configuração política e administrativa. Segundo o discurso político na campanha, devia-se romper o aparelhamento dos vereadores em favor da competência técnica dos Subprefeitos. Para Walter Feldmann (2008), Secretário das Subprefeituras, mesmo havendo a participação

\footnotetext{
${ }^{84}$ Não foi analisado o caso de São Miguel Paulista, que parece ser um terceiro padrão de dominação política, onde o PT manteve a direção local, mas compartilhou postos chave com outro partido (nessa região, o PTB).
} 
de aliados nos bairros, não haveria loteamento fisiológico de cargos. Entretanto, ex-prefeitos aliado de outras cidades assumiram, por exemplo, no Butantã (Maurício Pinterich, de Piraju), Itaquera (Laert Teixeira, de São João da Boa Vista) e M'Boi Mirim (Lacir Baldusco, de Itapecerica da Serra). ${ }^{85}$ A base desse discurso era evitar que Subprefeitos representassem vereadores nas regiões, além de não terem interesse eleitoral local que, se ocorresse, enfrentaria problemas para firmá-los como lideranças de bairro. Mas os vereadores aliados mantiveram indicações nas Subprefeituras, tal como no governo do PT. E administrativamente, políticas públicas como saúde, educação e cultura, por exemplo, foram recentralizadas, o que reduziu, ao menos em nível formal, o poder decisório dos Subprefeitos.

Nas duas gestões de Gilberto Kassab (DEM/2006-2008; 2009/2010; PSD/2011-2012), as Subprefeituras vêm perdendo espaço na administração municipal. De 2007 a 2010, o orçamento das regiões se reduziu em R $\$ 30$ milhões, ainda que a Secretaria de Coordenação das Subprefeituras ampliasse sua verba em quase R \$ 70 milhões, segundo O Estado de São Paulo (12/07/2010), o que parece ter ampliado a centralização em detrimento da ação local. Para 2011, segundo O Estado de São Paulo (15/10/2010), as Subprefeituras responderão por apenas 2,5\% das verbas municipais, o menor porcentual desde sua criação em 2002. Ao mesmo tempo, obras e serviços locais foram centralizados em seis Secretarias municipais ocupadas por pessoas diretamente ligadas ao Prefeito. Por fim, segundo o Estado de São Paulo (10/01/2011), já eram 16 os coronéis da reserva da Polícia Militar nomeados como Subprefeitos, 20 como Chefes de Gabinete e 23 no segundo escalão. Nesse contexto, a principal queixa dos vereadores é que, no governo do PT, havia mais espaço para indicarem Subprefeitos e incidirem na gestão local.

Como as Subprefeituras existem desde 2002, e já passaram por três diferentes governos e partidos, o estudo iniciado nessa dissertação pode ser ampliado para se discutir as distintas visões políticas e administrativas da descentralização na cidade de São Paulo. Sobretudo, em face das mudanças que as Subprefeituras sofreram nesses nove anos, pode-se questionar se é possível identificar um modelo de descentralização à reorganização gerencial do Estado em nível intra-municipal. Ou, se as alterações ocorridas nas Subprefeituras mostram que se trata de uma política ajustada ao partido que governa e que calibra o nível da descentralização conforme seus fins. Em síntese, o estudo das Subprefeituras seria uma forma de também analisar como a política e a gestão se relacionam em diferentes partidos políticos.

\footnotetext{
${ }^{85}$ Aqui, o prefeito eleito José Serra se pautava por dois jogos políticos distintos: no plano local, a construção da sua liderança no governo, para o que indicar ex-prefeitos do interior era útil, e no plano estadual, acumular forças contra o governador Geraldo Alckmin (PSDB), visando às eleições de 2006, para o que se apoiar em ex-prefeitos do interior também era importante.
} 


\section{REFERÊNCIAS BIBLIOGRÁFICAS}

ABRANCHES, S.H. Presidencialismo de Coalizão: o dilema institucional brasileiro. Dados Revista de Ciências Sociais, Rio de Janeiro, v. 31, n.1, p. 5-34, 1988.

ABRUCIO, F.L. A coordenação federativa no Brasil: a experiência do período FHC e os desafios do governo Lula. Revista de Sociologia Política, Curitiba, n.24, p. 41-67, jun.2005.

ADMINISTRAÇÃO REGIONAL DA CAPELA DO SOCORRO. Governo Local da Capela do Socorro - Plano de Ação Local. São Paulo; 2002. 61 p.

2002. 43 p.

Governo Local da Capela do Socorro - Planejamento Estratégico. São Paulo;

AFONSO, J.R.R.; ARAÚJO, E. A. A capacidade de gasto dos municípios brasileiros: arrecadação própria e receita disponível. Cadernos Adenauer: Os municípios e as eleições de 2000, São Paulo, n.4, p. 35-57, jun.2000.

AFFONSO, R.B.A. Descentralização e reforma do Estado: a Federação brasileira na encruzilhada. Economia e Sociedade, Revista de Economia da Unicamp, Campinas, p. 127-152, n. 14, jun., 2000.

ALMEIDA, M.H.T. Federalismo e proteção social: a experiência brasileira comparada. Disponível em: < www.fflch.usp.br/dcp/almeida. >. Acesso: 20 Mar. 2009.

40, jun., 2005.

Recentralizando a Federação? Revista de Sociologia e Política, Curitiba, n.24, p.29-

ARRETCHE, M.T.S. Mitos da descentralização: mais democracia e eficiência nas políticas públicas. Revista Brasileira de Ciências Sociais, São Paulo, v. 11, n. 31, p.44-66, jun, 1996.

Políticas Sociais no Brasil: descentralização em um Estado Federativo. Dados Revista Brasileira de Ciências Sociais, Rio de Janeiro, v. 14, n.40, p. 111-141, Jun., 1999.

Federalismo e Relações Intergovernamentais no Brasil: A Reforma de Programas

Sociais. Dados - Revista Brasileira de Ciências Sociais, Rio de Janeiro, v. 45, n.3, p. 431458, 2002.

Federalismo e políticas sociais no Brasil: problemas de coordenação e autonomia.

São Paulo em Perspectiva, São Paulo, v. 18, n.2, p. 17-26, 2004.

BACHRACH, P.; BARATZ, M.S. Two Faces of Power. The American Political Science Review, Los Angeles, v.56, n. 4., p. 947-952, Dec., 1962.

BARRAL, M. O MDB da Freguesia do Ó: estudo da participação política no contexto urbano. Projeto de dissertação de mestrado apresentado para o Departamento de História. São Paulo: Universidade de São Paulo, 1994. 45 p.

BELLO, C.A. Orçamento, redistribuição e participação popular no Município de São Paulo. São Paulo em Perspectiva, São Paulo, v. 20, n.3, p. 95-105, jul./set., 2006.

BOBBIO, N. Estado, governo e sociedade: por uma teoria geral da política. Trad. MA Nogueira. Rio de Janeiro: Paz e Terra, 2004. 173 p. 
BORJA, J. Descentralización: una cuestión de método. Revista Mexicana de Sociologia, Ciudad del México, v.46, n.4., p. 5-33, Oct.-Dec., 1984.

BOSCHI, R. R. Governança, Participação e Eficiência das Políticas Públicas: Exame de Experiências Municipais no Brasil. Disponível em: < http://www.fundaj.gov.br/docs/eg/semi0.html >. Acesso: 30 Jun. 2008.

CAMPOS, C.M; GAMA, L.H; SACCHETA, V. (orgs). São Paulo, metrópole em trânsito: percursos urbanos e culturais. São Paulo: Editora Senac São Paulo; 2004. 263 p.

CAPUCCI, P. Subprefeituras em São Paulo: o menor é melhor? In: R. Garibe e P. Capucci. Gestão local nos territórios da cidade: ciclo de atividades com as subprefeituras. São Paulo: Mídia Alternativa: Secretaria Municipal das Subprefeituras; 2004. p. 19-24.

CASTELlS, M. A Questão Urbana. Rio de Janeiro: Paz e Terra, 1983. 506 p.

Cidade, democracia e socialismo. Trad. G. Rodriguez. Rio de Janeiro: Paz e Terra, 1989. $193 \mathrm{p}$.

CASTELlS, M.; Borja, J. As cidades como atores políticos. Novos Estudos. São Paulo, n. 45, p. 152-166, Julho, 1996.

COUTO, C.G. Negociação, Decisão e Governo: Padrões Interativos na Relação ExecutivoLegislativo e o Caso Paulistano. In: Andrade, R.C. Processo de Governo no Município e no Estado. São Paulo: Edusp; 1998. p. 41-72.

COLIGAÇÃO MUdA SÃO PAULO. Programa de Governo. São Paulo, 2000.35 p.

DAHL, R.A. A Critique of the Ruling Elite Model. The American Political Science Review, Los Angeles, v. 52, n.2, p. 463-469, Jun., 1958.

Who Participates in Local Politics and Why. American Association for the Advancement of Science, Los Angeles, v. 134, n. 3487, p.1340-1348, Oct.,1961.

Who Governs? Democracy and Power in a American City. New Haven and London: Yale University Press; 1989. 355 p.

DAVIS, M. Cidade de Quartzo: escavando o futuro em Los Angeles. 1 ed. São Paulo: Scritta Editorial; 1993. 378 p.

DIAS, M. Sob o signo da vontade popular: O Orçamento Participativo e o dilema da Câmara Municipal de Porto Alegre. Belo Horizonte: Ed. UFMG; Rio de Janeiro: IUPERJ; 2000. 305 p.

DONATO, A. A descentralização em São Paulo. In: Gaspar, R.; Akerman, M.; Garibe, R. Espaço Urbano e Inclusão Social: a gestão pública na cidade de São Paulo (2001-2004). São Paulo: Editora Fundação Perseu Abramo; 2006 p. 35-42.

FALCÃO, R. Gestão pública, política e ideologia. In: Gaspar, R.; Akerman, M; Garibe, R. Espaço Urbano e Inclusão Social: a gestão pública na cidade de São Paulo (2001-2004). São Paulo: Editora Fundação Perseu Abramo; 2006.p. 305-318. 
FALLETI, T. Efeitos da descentralização nas relações intergovernamentais: o Brasil em perspectiva comparada. Sociologias, Porto Alegre, n. 16, p. 46-85, jul./dez., 2006.

FARAH, M.F.S. Inovação e governo local no Brasil contemporâneo. In: Jacobi, P.; Pinho, J.A. Inovação no campo da gestão pública local: novos desafios, novos patamares. Rio de Janeiro: Editora FGV; 2006. p. 41-76.

FELDMAN, W. São Paulo, o bom combate da paz. São Paulo: Contexto, 2008. 155 p.

FERNANDEZ, J.C.A.; MENDES, R. Subprefeituras em São Paulo e Políticas Públicas para Qualidade de Vida. São Paulo: Cepedoc; 2003. [Recuperado em 20 de Janeiro de 2010]. Sítio web: www. cidadessaudaveis.org.br/qualivida.pdf.

FERNANDEZ, J.C.A.; Bógus, C.M.; Mendes, R. O método da sistematização: uma leitura crítica do processo. In: Westphal, M.F.; PAIS, T.D. Capela Saudável: Gestão de Políticas Públicas Integradas e Participativas. São Paulo: Edusp; 2006. p.113-129.

FINATEC. Descentralização e poder local: a experiência das subprefeituras no município de São Paulo. São Paulo: Hucitec; 2004. 141 p.

GARIBE, R. A descentralização do poder em São Paulo. In: Garibe, R.; Capucci, P. Gestão local nos territórios da cidade: ciclo de atividades com as subprefeituras. São Paulo: Mídia Alternativa: Secretaria Municipal das Subprefeituras; 2004. p. 13-18.

GARIBE, R. Estado e descentralização. In: Gaspar, R.; Akerman, M.; Garibe, R. Espaço Urbano e Inclusão Social: a gestão pública na cidade de São Paulo (2001-2004). São Paulo: Editora Fundação Perseu Abramo; 2006. p. 25-34.

HALL, P.A. Policy Paradigms, Social Learning, and the State: The Case of Economic Policymaking in Britain. Comparative Politics, New York, v.25, n.3, p. 275-296, Apr., 1993.

HALL, P.A.; TAYLOR, R.S.R. As três versões do neo-institucionalismo. Lua Nova Revista de Cultura e Política, São Paulo, n. 58, p. 193-223, 2003.

HOGWOOD, B.; GUNN, L. Why 'perfect implementation' is unattainable In: Hill, M. The Policy Process: A Reader. Newcastle: Harvester Wheatsheaf; 1993. p. 238-247.

HUNTER, F. Community Power Structure: a study of decision makers. 4. ed. The University of North Carolina Press: Chapel Hill;1973. 297 p.

IMMERGUT, E. The rules of the game: The logic of health policy-making in France, Switzerland, and Sweden. In: Steinmo, S.; Thelen, K.; Longstreth, F. Structuring politics: historical institucionalism in comparative analysis. Cambridge: Cambridge University Press; 1992. p. 57-89.

The teoretical Core of the New Institucionalism. Politics \& Society, v. 26, n. 1, p. 534, March, 1998.

JACOBI, P. Descentralização municipal e participação dos cidadãos: apontamentos para o debate. Lua Nova Revista de Cultura e Política, São Paulo, n.20, p.121-143, Maio, 1990. 
Políticas públicas e alternativas de inovação da gestão municipal: o complexo caso da cidade de São Paulo. São Paulo em Perspectiva, São Paulo, v.5, n. 2, p. 31-37, abril/jun., 1991.

KEINERT, T.M.M. Reforma administrativa nos anos 90: o caso da prefeitura Municipal de São Paulo. Revista de Administração de Empresas, São Paulo, v.33, n.4, p. 66-81, Jul/Ago., 1993.

KING, D. The establishment of work-welfare programs in the United States and Britains: Politics, Ideas and Institutions. In: Steinmo, S.; Thelen, K.; Longstreth, F. Structuring politics: historical institucionalism in comparative analysis. Cambridge: Cambridge University Press; 1992. p. 217-250.

KUGELMAS, E.; SOLA, L. Recentralização/Descentralização: dinâmica do regime federativo no Brasil dos anos 90. Tempo Social. Revista de Sociologia da USP, v.11, n.2, p.63-81, out.,1999.

KUSCHNIR, K. O Cotidiano da Política. Rio de Janeiro: Jorge Zahar Ed.; 2000. 162 p.

LAMEIRÃO, C.R. Estratégias políticas e gestão local: as subprefeituras do município do Rio de Janeiro. 2007. 127.p. Dissertação (Mestrado em Ciência Política) - Instituto de Ciências Humanas e Filosofia, Universidade Federal Fluminense, Rio de Janeiro.

LE GALÈS, P. Urban governance in Europe: What is governed? Paris: Centre d'études europénnes (mimeografado), 2010, 15 p.

LICO, F.M.C; FERNANDEZ, R.M.A. A experiência vivida: projeto Capela Saudável. In: Westphal, M.F.; PAIS, T.D. Capela Saudável: Gestão de Políticas Públicas Integradas e Participativas. São Paulo: Edusp; 2006. p.48-85.

LOWI, T,J. American Business, Public Policy, Case Studies, and Political Theory. World Politics, Baltimore, v.16, n.4, p. 677-715, Jul. 1964.

MARCH, J.G; OLSEN, J.P. The New Institucionalism: Organizacional Factors in Political Life. The American Political Science Review, Washington, v.78, n.3, p.734-749, September, 1984.

MAQUIAVEL, N. O Príncipe. Rio de Janeiro: Civilização Brasileira, 1983. 158 p.

MARQUES, E.C. Redes sociais, instituições e atores políticos no governo da cidade de São Paulo. São Paulo: Annablume: Fapesp; 2003. 248 p.

Redes Sociais e poder no Estado brasileiro: aprendizados a partir de política urbanas. Revista Brasileira de Ciências Sociais, São Paulo, v. 21, n. 60, p.15-42, fevereiro, 2006.

MARTINS, M.L.R. Descentralização e Subprefeituras em São Paulo. Disponível em: < www.usp.br/fau/depprojeto/labhab/.../martinsdescentralizaerundina.pdf.>. Acesso: 15 Jan. 2010.

MARTINS, J.D. As regras da metrópole: campo urbanístico e ordem social na região metropolitana de São Paulo. 2006. 301 p. Tese (Doutorado em Sociologia) - Departamento de Sociologia do Instituto de Ciências Sociais, Universidade de Brasília, Brasília. 
MELO, M.A. Crise federativa, guerra fiscal e "hobbesianismo municipal: efeitos perversos da descentralização? São Paulo em Perspectiva, São Paulo, v.10, n.3, p.11-20, 1996.

MENDES, M. Governabilidade no Município de São Paulo. Disponível em: < http://www. braudel.org.br/pesquisas/pdf/mmendes02.pdf.> . Acesso: 08 Jan. 2010.

MILLS, C.W. A Elite do Poder. 2. ed. Rio de Janeiro: Zahar Editores; 1968. 421 p.

MOLLENKOPF, JH. The rise and fall of the Koch coalition in New York City politics. New Jersey: Princeton University Press; 1992. 307.

NOGUEIRA, M.A. A dimensão política da descentralização participativa. São Paulo em Perspectiva, São Paulo, v.11, n.3, p.9-19, 1997.

OSBORNE, D.; GAEBLER, T. Reinventando o governo: como o espírito empreendedor está transformando o setor público. 10 ed. Brasília: MH Comunicação; 1998. 436 p.

OLIVEIRA, C.A.B. (coord). Políticas públicas de combate à pobreza no município de São Paulo. São Paulo: Ed. Publisher Brasil Ltda.; 2004. 207 p.

POLSBY, N.W. How to Study Communitiy Power: The Pluralist Alternative. The Journal of Politics, Cambridge, v. 22, n.3, p. 474-484, Aug., 1960.

PREFEITURA MUNICIPAL DE SÃO PAULO. Proposta de novo modelo de estrutura organizacional. São Paulo: Secretaria Especial da Reforma Administrativa, 1991a. 49 p.

Nova Territorialização. São Paulo: Secretaria das Administrações Regionais: Assessoria Técnica de Sistemas de Informática, 1991b. 22 p.

. O poder em São Paulo: história da administração pública na cidade, 1554-1992. São Paulo: Cortez; 1992a.159 p.

São Paulo: Crise e Mudança. São Paulo: Brasiliense, 1992b. 215 p.

. Globalização e desenvolvimento urbano. São Paulo: Secretaria Municipal de Planejamento; 2000/2001. 56 p.

Projeto de lei 546/2001 encaminhado à Câmara Municipal pela Sra. Prefeita que dispõe sobre a criação de Subprefeituras no município de São Paulo e dá outras providências.

A economia da grande cidade: desafios da política urbana em São Paulo. São Paulo: Secretaria Municipal de Planejamento; 2002. 83 p.

Plano de ação - governo local - 2002/2003: rumo às Subprefeituras. Secretaria de Implementação das Subprefeituras - SIS; 2002.

Subprefeituras - documentos sobre a descentralização político-administrativa do Município de São Paulo. São Paulo: Secretaria Municipal das Subprefeituras; 2002.

Orçamento Participativo - Ciclo Temático 2002. São Paulo: Coordenadoria do Orçamento Participativo; 2003. 23 p.

Sumário de Dados 2004. São Paulo: Secretaria de Governo Municipal; 2004. 394 p. 
RAGIN, C.C. The Comparative Method: moving beyond qualitative and quantitative strategies. Califórnia: University California Press; 1987. 185 p.

SABATIER, P. Top-down and bottom-up approaches to implementation research. In: Hill, M. The Policy Process: A Reader. Newcastle: Harvester Wheatsheaf; 1993. p. 266-296.

SADER, E. Governar para Todos: uma avaliação da gestão Luiza Erundina. São Paulo: Scritta Editorial; 1992. 134 p.

SANTOS, UP. e BARRETTA, D. As Subprefeituras em São Paulo. São Paulo: Hucitec: Prefeitura Municipal de São Paulo; 2004. 203 p.

SILVA, C.G. et al. Repercussões do projeto Capela Saudável: ações integradas de políticas públicas no cotidiano das Coordenadorias. In: Westphal, M.F.; PAIS, T.D. Capela Saudável: Gestão de Políticas Públicas Integradas e Participativas. São Paulo: Edusp; 2006. p.87112.

SKOCPOL, T. Bringing the state back in: strategies of analisys in current research. In: Evans, P.B; Ruesschemeyer, D.; Skocpol, T. Bringing the state back in. Cambridge: Cambridge University Press; 2002. p. 3-41.

SOUZA, C. Federalismo, desenho constitucional e instituições federativas no Brasil pós1988. Revista de Sociologia e Política, Curitiba, n. 24, p.105-121, jun.2005.

. Governos locais e gestão de políticas sociais universais. São Paulo em Perspectiva, São Paulo, v.18, n.2, p.27-41, 2004.

Governos e sociedades locais em contextos de desigualdades e de descentralização. Ciência \& Saúde Coletiva, v.7, n.3, p.431-442, 2002.

SOUZA, C.; CARVALHO, I. M. M. Reforma do Estado, Descentralização e Desigualdades. Lua Nova, São Paulo, n. 48, p. 187-213, 1999.

SOUZA, C.; BLUMN, M. Autonomia política local em contextos de desigualdades intra e inter-regionais. In: Encontro da Associação Nacional de Pós-Graduação e Pesquisa em Administração, 23., 1999, São Paulo, Trabalhos Apresentados. São Paulo: Associação Nacional de Pós-Graduação em Administração, 1999, 15.

SPOSATI, A. A cidade em pedaços. São Paulo: Editora Brasiliense; 2001. 173 p.

SPOSATI, A. Superando o discurso da descentralização municipal. In: Calderón, A.I; Chaia, V. Gestão Municipal: descentralização e participação popular. São Paulo: Cortez; 2002. p.73-82.

STONE, C.N. Power in Community Decision Making:A Restatement of Stratification Theory. The American Political Science Review, Los Angeles, v. 74, n. 4, p. 978-990, Dec., 1980.

SUBPREFEITURA DA CAPELA DO SOCORRO. Relatório Propositivo do Plano Diretor Regional da Capela do Socorro. São Paulo, 2003, 231 p.

SUBPREFEITURA DA FREGUESIA DO Ó. Brasilândia: construindo um Bairro Legal (A experiência do Grupo de Trabalho Ampliado Bairro Legal). São Paulo, 2003, 9 p. 
SUPLICY, M. Resgatando a dignidade da nossa cidade. In: Calderón, A.I.; Chaia, V. Gestão Municipal: descentralização e participação popular. São Paulo: Cortez; 2002. p.113-122.

TATAGIBA, L.; TEIXEIRA, A.C.C. Movimentos sociais e sistema político: os desafios da participação. Observatório dos Direitos do Cidadão: acompanhamento e análise das políticas públicas da cidade de São Paulo, Instituto Polis: PUC-SP, 2005, 25: 1-19.

TATTO, J. Governo Marta: eficiente e com prioridade. In: Gaspar, R.; Akerman, M.; Garibe, R. Espaço Urbano e Inclusão Social: a gestão pública na cidade de São Paulo (20012004). São Paulo: Editora Fundação Perseu Abramo; 2006. p. 291-304.

TEIXEIRA, M.A.C. Negociação política e as formas de interação Executivo Legislativo no Brasil no período de 1983 a 1992. Cadernos Gestão Pública e Cidadania. São Paulo: Fundação Getulio Vargas, 2004. 77 p.

THELEN. K.; STEINMO, S. Historical institucionalism in comparative politics. In: Steinmo, S.; Thelen, K.; Longstreth, F. Structuring politics: historical institucionalism in comparative analysis. Cambridge: Cambridge University Press; 1992. p. 1-32.

TILLY, C. Big structures, large process, huge comparisons. Michigan: University of Michigan, 1983. 143 p.

TOCQUEVILle, A. A democracia na América. Trad. Nei. R. Silva, 2 ed. Belo Horizonte: Ed. Itatiaia; São Paulo: Editora da Universidade de São Paulo, 1977, 620 p.

TORRECILLAS, S; SOUSA, G. J. Partilha administrativa: descentralização do governo e poder na cidade de São Paulo (2001-2004). In: Gaspar, R.; Akerman, M.; Garibe, R. Espaço Urbano e Inclusão Social: a gestão pública na cidade de São Paulo (2001-2004). São Paulo: Editora Fundação Perseu Abramo; 2006. p. 43-48.

VITALE, D. Orçamento Participativo em São Paulo (2001-2002). Observatório dos Direitos do Cidadão: acompanhamento e análise das políticas públicas da cidade de São Paulo. Instituto Polis: PUC-SP, 2004,18: 1-76.

WEIR, M. Ideas and politics of bounded innovation. In: Steinmo, S.; Thelen, K.; Longstreth, F. Structuring politics: historical institucionalism in comparative analysis. Cambridge: Cambridge University Press; 1992. p. 188-216.

WESTPHAL, M.F.; PAIS, T.D. Conclusão. In: Capela Saudável: Gestão de Políticas Públicas Integradas e Participativas. São Paulo: Edusp; 2006. p.131-134. 


\section{OUTRAS FONTES}

CÂMARA MUNICIPAL DE SÃO PAULO. Projeto de lei 001/01 que dispõe sobre a sobre a criação, composição e atribuições do Conselho de Representantes, janeiro de 2001.

Substitutivo do ver. José Laurindo (PT) ao projeto de lei n. 001/01 que dispõe sobre a criação, composição de atribuições do Conselho de Representantes, junho 2001.

. Proposta de Decreto Legislativo sobre a criação, composição e atribuições do Conselho de Representantes, dezembro de 2001.

Lei Orgânica do Município de São Paulo. Disponível em:< http://www.camara.sp.gov.br/images/stories/legislacao/Lei-Organica >. Acesso:18 Jan. 2010.

PREFEITURA MUNICIPAL DE SÃO PAULO. Lei n. 13.169, de 11 de julho de 2001. Dispõe sobre a reorganização parcial das estruturas organizacionais das Secretarias Municipais que especifica e dá outras providências. Diário Oficial da Cidade de São Paulo.

. Lei n. 13399, de 17 de julho de 2002. Dispõe sobre a criação de Subprefeituras no município de São Paulo. Diário Oficial da Cidade de São Paulo, São Paulo, 01 Ago. 2002.

Lei n. 13682, de 15 de dezembro de 2003. Dispõe sobre a estrutura organizacional das Subprefeituras. Diário Oficial da Cidade de São Paulo, São Paulo.

. Lei n. 13881, de 15 de dezembro de 2003. Dispõe sobre a criação, composição, atribuições e funcionamento do Conselho de Representantes e dá outras providências. Diário Oficial da Cidade de São Paulo, São Paulo, SP.

Decreto n. 40227, de 01 de janeiro de 2001. Altera denominação da Secretaria Municipal das Administrações Regionais. Diário Oficial da Cidade de São Paulo.

. Decreto n. 41813, de 15 de março de 2002. Dispõe sobre a instituição do Governo Local no âmbito territorial. Diário Oficial da Cidade de São Paulo, São Paulo.

. Decreto n. 42325, de 22 de agosto de 2002. Dispõe e classifica os Órgãos e Unidades Orçamentárias no âmbito das Subprefeituras. Diário Oficial da Cidade de São Paulo, São Paulo.

Decreto n. 42561, de 30 de outubro de 2002. Dispõe sobre a coordenação da implantação das Subprefeituras. Diário Oficial da Cidade de São Paulo, São Paulo.

Decreto n. 42670, de 02 de dezembro de 2002. Dispõe sobre a transferência de instâncias decisórias da Secretaria Municipal das Subprefeituras para as Subprefeituras. Diário Oficial da Cidade de São Paulo, São Paulo.

Decreto n. 42771, de 03 de janeiro de 2003. Dispõe sobre a transferência da Secretaria Municipal de Saúde para as Subprefeituras Diário Oficial da Cidade de São Paulo, São Paulo.

Decreto n. 42772, de 03 de janeiro de 2003. Dispõe sobre a transferência da Secretaria Municipal de Educação para as Subprefeituras Diário Oficial da Cidade de São Paulo, São Paulo. 
Decreto n. 43796, de 16 de setembro de 2003. Dispõe sobre a transferência da Secretaria Municipal de Abastecimento para as Subprefeituras Diário Oficial da Cidade de São Paulo, São Paulo.

Decreto n. 43799, de 16 de setembro de 2003. Dispõe sobre a transferência da Secretaria Municipal de Abastecimento para as Subprefeituras Diário Oficial da Cidade de São Paulo, São Paulo.

Decreto n. 43822, de 18 de setembro de 2003. Dispõe sobre providências da transferência da administração dos Centros Educacionais Unificados para as Subprefeituras Diário Oficial da Cidade de São Paulo, São Paulo.

Decreto n. 44418, de 26 de fevereiro de 2004. Dispõe sobre a transferência de parte das competências da Secretaria de Habitação e Desenvolvimento Urbano as Subprefeituras. Diário Oficial da Cidade de São Paulo, São Paulo.

Decreto n. 45438, de 22 de outubro de 2004. Dispõe sobre a transferência de Centros de Convivência da Secretaria Municipal da Assistência Social para as Subprefeituras. Diário Oficial da Cidade de São Paulo, São Paulo.

Decreto n. 45551, de 29 de novembro de 2004. Regulamenta lei 13.881 que dispõe sobre o Conselho de Representantes. Diário Oficial da Cidade de São Paulo, São Paulo.

Decreto n. 45683, de 01 de janeiro de 2005. Dispõe sobre a organização, atribuições e funcionamento da Administração Municipal Direta. Diário Oficial da Cidade de São Paulo, São Paulo.

Decreto n. 45713, de 10 de fevereiro de 2005. Modifica parcialmente a estrutura organizacional das Subprefeituras. Diário Oficial da Cidade de São Paulo, São Paulo.

Decreto n. 45787, de 23 de março de 2005. Dispõe sobre a transferência das Coordenadorias de Educação das Subprefeituras que especifica para a Secretaria Municipal de Educação. Diário Oficial da Cidade de São Paulo, São Paulo.

Decreto n. 46209, de 15 de agosto de 2005. Dispõe sobre a transferência das Coordenadorias de Saúde das Subprefeituras que especifica para a Secretaria Municipal de Saúde. Diário Oficial da Cidade de São Paulo, São Paulo.

Decreto n. 46414, de 30 de setembro de 2005. Transfere a execução do Plano de Pavimentação Urbana Comunitária para a Secretaria Municipal de Coordenação das Subprefeituras. Diário Oficial da Cidade de São Paulo, São Paulo.

Decreto n. 46434, de 06 de outubro de 2005. Dispõe sobre a transferência de equipamentos culturais das Subprefeituras que especifica para a Secretaria Municipal de Cultura. Diário Oficial da Cidade de São Paulo, São Paulo.

Decreto n. 47338, de 01 de junho de 2006. Altera lotação de cargos em comissão das unidades de esportes das Subprefeituras transferidos para a Secretaria Municipal de Educação. Diário Oficial da Cidade de São Paulo, São Paulo.

. SMSP/SGM/SGP. Dispõe sobre a estrutura organizacional das Subprefeituras.

Portaria Intersecretarial n. 6, Diário Oficial da Cidade de São Paulo, São Paulo, 2002, 


\section{ENTREVISTAS REALIZADAS}

\section{Prefeitura Municipal de São Paulo}

Aldaíza Sposati, Secretária Municipal de Assistência Social.

Félix Sanchez, Coordenador Municipal do Orçamento Participativo da PMSP.

Ubiratan dos Santos, Chefe de Gabinete da Secretaria de Governo Municipal.

\section{Subprefeitura da Freguesia do Ó}

Walter Alcântara, Subprefeito.

Ana Vellardi, Coordenadora de Habitação da Região Norte.

Elza Ramello, Coordenadora de Educação.

Francisco Rodrigues, Supervisor de Assistência Social.

Genilson da Silva Santos, Chefe de Gabinete.

Luiz Brito de Brito, Coordenador do Orçamento Participativo.

Mirca Bonano, Supervisora de Cultura.

Neli Márcia Ferreira (Márcia Barral), Subprefeita.

Tereza Nakagawa, Representante local da Secretaria Municipal de Trabalho e Desenvolvimento Solidário.

\section{Subprefeitura da Capela do Socorro}

Tadeu Dias Pais, Subprefeito.

Cássia Goreti da Silva, Chefe de Gabinete.

Jane Armond, Coordenadora de Saúde.

Jorge Ribeiro, Coordenador de Educação da Região 6 (zona sul da cidade).

Juan Aneros Fernandez, Assessor do Subprefeito.

Jussara Vidal, Coordenadora de Assistência Social e Desenvolvimento.

Loide Parlato, Coordenadora de Planejamento e Desenvolvimento Urbano.

Regina Aneros Fernandez, Assessora do Subprefeito. 